Published in final edited form as:

J Med Chem. 2016 February 11; 59(3): 892-913. doi:10.1021/acs.jmedchem.5b01305.

\title{
Property Focused Structure-Based Optimization of Small Molecule Inhibitors of the Protein-Protein Interaction between Menin and Mixed Lineage Leukemia (MLL)
}

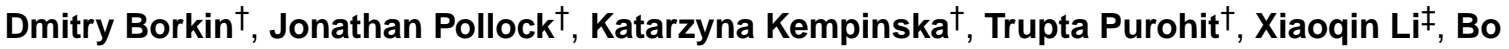 \\ Wen $^{\ddagger}$, Ting Zhao ${ }^{\ddagger}$, Hongzhi Miao ${ }^{\dagger}$, Shirish Shukla ${ }^{\dagger}$, Miao He ${ }^{\ddagger}$, Duxin Sun ${ }^{\ddagger}$, Tomasz \\ Cierpicki $^{\dagger}$, and Jolanta Grembecka ${ }^{\star}, \dagger$ \\ †Department of Pathology, University of Michigan, 1150 W. Medical Center Drive, Ann Arbor, \\ Michigan 48109, United States \\ ¥College of Pharmacy, University of Michigan, Ann Arbor, Michigan 48109, United States
}

\begin{abstract}
Development of potent small molecule inhibitors of protein-protein interactions with optimized druglike properties represents a challenging task in lead optimization process. Here, we report synthesis and structure-based optimization of new thienopyrimidine class of compounds, which block the protein-protein interaction between menin and MLL fusion proteins that plays an important role in acute leukemias with $M L L$ translocations. We performed simultaneous optimization of both activity and druglike properties through systematic exploration of substituents introduced to the indole ring of lead compound 1 (MI-136) to identify compounds suitable for in vivo studies in mice. This work resulted in the identification of compound 27 (MI-538), which showed significantly increased activity, selectivity, polarity, and pharmacokinetic profile over 1 and demonstrated a pronounced effect in a mouse model of MLL leukemia. This study, which reports detailed structure-activity and structure-property relationships for the menin-MLL inhibitors, demonstrates challenges in optimizing inhibitors of protein-protein interactions for potential therapeutic applications.
\end{abstract}

\section{Graphical abstract}

\footnotetext{
“Corresponding Author: jolantag@umich.edu. Phone: 734-615-9319. Fax: 734-763-8764.

Supporting Information

The Supporting Information is available free of charge on the ACS Publications website at DOI: 10.1021/acs.jmed-chem.5b01305. Table 1 with profiling of compound $\mathbf{1}$ on a panel of kinases, Table 2 with profiling of compound $\mathbf{1}$ on a panel of GPCRs, Table 3 with crystallography data, Table 4 with Caco- 2 membrane permeability data, Figure 1 with selected titration curves from the FP assay, and Figure 2 with phase II metabolism data (PDF)

Accession Codes

The atomic coordinate files have been deposited in PDB with the PDB codes 5DB0, 5DB1, 5DB2, and 5DB3.

Notes

The authors declare the following competing financial interest(s): Dmitry Borkin, Jolanta Grembecka, Tomasz Cierpicki, Duxin Sun, and Xiaoqin Li are inventors in the patent filed by the University of Michigan, which covers the menin-MLL inhibitors disclosed in the current study. The patent has been licensed by Kura Oncology, Inc. Drs. Grembecka and Cierpicki receive research support from Kura Oncology. They are also receiving compensation as members of the scientific advisory board of Kura Oncology, and they have an equity ownership in the company. Other co-authors declare no potential conflict of interest.
} 


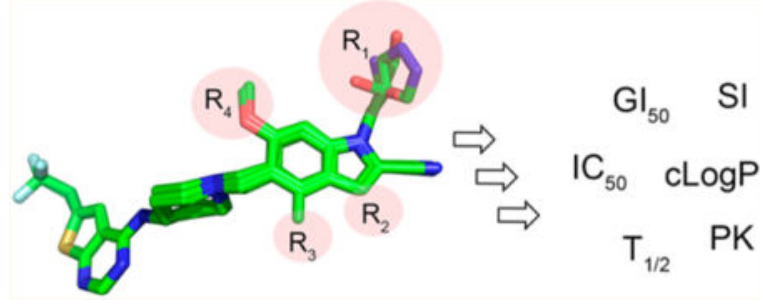

\section{INTRODUCTION}

The protein-protein interaction between menin and MLL (mixed lineage leukemia) fusion proteins plays a critical role in acute leukemias with translocations of the $M L L$ gene. ${ }^{1}$ The MLL leukemias constitute about 5-10\% of acute leukemia cases in adults, both AML (acute myeloid leukemia) and ALL (acute lymphoblastic leukemia), ${ }^{2}$ and $~ 70 \%$ of acute leukemias in infants. ${ }^{3}$ Patients with MLL leukemias do not respond well to currently available treatments, ${ }^{4-6}$ emphasizing the need for more effective therapies.

The MLL fusion proteins, which result from the chromosomal translocations of the $M L L$ gene, retain the N-terminal fragment of MLL (about 1400 amino acids) ${ }^{7,8}$ that is involved in the protein-protein interaction (PPI) with menin. ${ }^{1,9}$ Importantly, the menin-MLL interaction plays a crucial role in the MLL fusion protein mediated leukemogenic transformation. ${ }^{1,10}$ Menin is required by MLL fusion proteins for enhanced proliferation and differentiation block of leukemic cells. ${ }^{1,11}$ We previously demonstrated that the N-terminal fragment of MLL binds with a high affinity to the large central cavity on menin ${ }^{9,12,13}$ and validated that this protein-protein interaction is amenable to small molecule inhibition. ${ }^{12,14-16}$ All these findings imply that the menin-MLL protein-protein interaction represents an attractive molecular target to develop new targeted agents as a potential therapeutic strategy for MLL leukemia.

Despite an important role of protein-protein interactions (PPIs) in human diseases, including cancer, ${ }^{17}$ targeting PPIs with small molecules is still considered a challenging task due to large contact areas, lack of well-defined pockets, and flexibility of residues at PPI interfaces. ${ }^{18,19}$ Furthermore, development of cell-permeable and orally bioavailable PPI inhibitors with optimized druglike properties represents an additional challenge. ${ }^{20}$ Despite these limitations, there are a number of successful examples of small molecules blocking PPIs. ${ }^{21-25}$ More importantly, PPI inhibitors have been successfully advanced to clinical trials, including small molecules activating apoptotic pathways, such as Bcl-2 inhibitors and p53 activators, ${ }^{26,27}$ providing evidence that PPI inhibitors might serve as novel therapeutics.

Our own work led to the identification of two distinct classes of menin-MLL inhibitors, which demonstrated relatively potent activity in MLL leukemia cells ${ }^{14,15,28}$ but were not optimized for in vivo studies. More recently, we developed a new class of menin-MLL inhibitors by linking the cyanoindole ring with the thienopyrimidine core through the aminopiperidine linker, Figure 1a and compound $\mathbf{1}$ (MI-136) in Table $1 .{ }^{16}$ However, this class, represented by the lead compound $\mathbf{1}\left(\mathrm{IC}_{50}=31 \mathrm{nM}\right.$, Table 1), requires further improvement of cellular activity and druglike properties, including metabolic stability, 
selectivity, and aqueous solubility, to develop compounds with potential therapeutic value. In this study we report structure-based optimization of compound $\mathbf{1}$ performed by systematic exploration of substituents introduced on the indole ring of $\mathbf{1}$, together with extensive characterization of their in vitro potency, cellular activity, selectivity, and microsomal stability to provide structure-activity and structure-property relationships. For several selected compounds we also determined the pharmacokinetic profile (PK) in mice. This work resulted in the identification of compound 27 (MI-538), which showed significantly improved activity, selectivity, and PK profile over $\mathbf{1}$ and demonstrated a pronounced effect in a mouse model of MLL leukemia. Interestingly, we discovered that simultaneous incorporation of multiple substituents optimized for each site on the scaffold does not always positively affect the activity or druglike properties of these compounds, proving an additional level of complexity in lead optimization. This study illustrates the difficulties and challenges in optimizing druglike properties of PPI inhibitors and emphasizes the need for extensive medicinal chemistry efforts combined with structural studies for successful optimization of such compounds.

\section{RESULTS AND DISCUSSION}

\section{Compound 1 Represents a Valuable Pharmacophore for Development of Menin-MLL Inhibitors}

We recently developed a new class of small molecule inhibitors of the menin-MLL interaction represented by compound $\mathbf{1}$, Figure 1a, Table $1 .{ }^{16}$ This compound strongly binds to menin $\left(K_{\mathrm{d}}=24 \mathrm{nM}\right)$, potently inhibits menin interaction with MLL $\left(\mathrm{IC}_{50}=31 \mathrm{nM}\right)$ (Table 1, Supporting Information Figure 1), and blocks proliferation of MLL leukemia cells at submicromolar concentrations $\left(\mathrm{GI}_{50}=0.55 \mu \mathrm{M}\right.$ in the MLL-AF9 cells, Table 1), validating that it represents a valuable pharmacophore for menin-MLL inhibitors. In addition, compound 1 did not show substantial off-target activity when profiled on a panel of kinases and GPCRs, Supporting Information Tables 1 and 2. Compound 1, however, requires further improvement of druglike properties, including (i) potency and selectivity toward MLL leukemia cells (selectivity index for $\mathbf{1}$, SI $<6$, Table 1 ), (ii) metabolic stability $\left(T_{1 / 2}=6.8\right.$ min in mouse liver microsomes), (iii) pharmacokinetic profile (PK), and (iv) polarity (clogP $=4.3$ ), implying the need for additional medicinal chemistry efforts.

The crystal structure of the menin in complex with 1 revealed that it binds to the MLL binding site on menin and occupies the $\mathrm{F} 9$ and $\mathrm{P} 13$ pockets, with the 2-cyanoindole ring extending beyond the $\mathrm{P} 13$ pocket to form a hydrogen bond with the side chain of Trp341, Figure 1a. On the basis of the crystal structure, we concluded that additional substitutions on the 2-cyanoindole ring of $\mathbf{1}$ could be explored by introducing substituents at positions 1, 3, 4, and 6 (substituents $R_{1}-R_{4}$, Figure $1 b$ ). Substitutions at $R_{2}$ and $R_{4}$ were not tested before, while only a limited set of substituents at $R_{1}$ and $R_{3}$ were probed in our recent study, ${ }_{1}$ providing a good rationale for much more systematic structure-activity relationship (SAR) combined with structure-property relationship studies. 


\section{Development of Analogues with Substitutions at Indole Nitrogen}

The crystal structure of the menin in complex with compound 1 revealed that the indole nitrogen in 1 is involved in a direct hydrogen bond with the side chain of Glu363 on menin (Figure 1a). This nitrogen atom is partly solvent exposed, suggesting that substituents of different size should be tolerable at this position. Furthermore, the close proximity of the side chains of Glu363 and Glu366 (Figure 1a) supports exploration of polar groups at $R_{1}$ for hydrogen bond formation. To identify optimal $\mathrm{R}_{1}$ substituents, we focused on introducing a variety of substituents harboring hydrogen bond donor groups at $\mathrm{R}_{1}$, Table 1 , with the goal to improve polarity while retaining or improving the potency of the new analogues.

First, we tested the hydroxyethyl group at $\mathrm{R}_{1}$ (compound 2 ), which was designed to form a hydrogen bond with one of the glutamic acid residues on menin, but no activity improvement was observed as compared to 1 (Table 1). We next designed compounds with 1,2-propanediol functional group or its derivatives (compounds 3-(RS) (MI-352), 3-(R), 3$(S), 4-(R), 4-(S), 5,6)$, Table 1) to further increase capabilities for hydrogen bond formation with Glu363 and/or Glu366. We found that neither compound 3-(RS), which represents a racemic mixture, nor individual enantiomers of this compound (3- $(\boldsymbol{R})$ and $3-(S))$ demonstrate better inhibitory activity than $\mathbf{1}$, Table 1 . To understand the molecular basis of inhibitory activity, we determined the crystal structure of menin in complex with $3-(R S)$, Figure 2a, Supporting Information Table 3. Interestingly, we observed that both enantiomers of 3-(RS) bind to menin in the same manner with the only difference being a distinct orientation of the secondary hydroxyl group, Figure 2a. This hydroxyl group is solvent exposed in both enantiomers, but only in one of them (3-R) it forms a hydrogen bond with Glu363, while the terminal hydroxyl group forms a hydrogen bond with Glu366 in both enantiomers of 3-(RS), Figure 2a. We next explored substitutions on the secondary hydroxyl group (compounds $4-(\boldsymbol{R}), \mathbf{4}-(\boldsymbol{S})$, and $\mathbf{6})$ and found almost no effect on the inhibition of the menin-MLL interaction as compared to 3-(RS), Table 1, while alkylation of the terminal hydroxyl group (compound $\mathbf{5}$ ) resulted in $\sim 3$-fold reduced inhibitory activity. Overall, the series of $\mathrm{R}_{1}$ substitutions with the 1,2-propanediol group or its derivatives did not improve inhibitory activity over $\mathbf{1}$ despite the formation of additional hydrogen bonds with menin by some of these compounds.

Incorporation of the acetamide group at $\mathrm{R}_{1}$ in compound 7 (MI-389), which results in formation of hydrogen bonds with both Glu363 and Glu366 as validated by the crystal structure of the complex (Figure 2b), also does not improve inhibition of the menin-MLL interaction (Table 1). We then introduced the $\boldsymbol{a}$-methylated acetamide group at $\mathrm{R}_{1}$ (compound $\mathbf{8}$ ), which showed about 10 -fold reduced inhibitory activity likely due to a limited space to accommodate an additional methyl group at this region of the binding site, Table 1.

Out of aromatic substituents at $\mathrm{R}_{1}$ (compounds 9 and 10, Table 1 ), we have recently explored a few five-member heterocycles harboring hydrogen bond donor groups, out of which the 4-methylpyrazole derivative (compound 10) showed best inhibitory activity ( $\mathrm{IC}_{50}$ $=23 \mathrm{nM}) \cdot{ }^{16}$ Here, we followed up on these findings and introduced the 4-methyltriazole substituent at $\mathrm{R}_{1}$ (compound 9 ) to further increase polarity of these compounds. Importantly, 
we were able to retain strong inhibitory activity of compound $\mathbf{9}$ while improving polarity represented by a significantly lower clogP value when compared to $\mathbf{1}$, Table 1 . Overall, despite the fact we did not improve substantially the in vitro inhibitory activity by substituting at $\mathrm{R}_{1}$ of $\mathbf{1}$, the majority of these compounds represent very potent inhibitors of the menin-MLL interactions with the $\mathrm{IC}_{50}$ values at the range of $25-45 \mathrm{nM}$, Table 1 . Importantly, these new analogues are more polar than 1, reflected by the clogP values below 3.5 for most of them, which affects their cellular activity and other druglike properties (see below).

In the next step we assessed cellular activities and microsomal stabilities of the series of menin-MLL inhibitors with various $\mathrm{R}_{1}$ substituents. Interestingly, despite similar in vitro activity, these compounds demonstrate substantially different cellular activity in MLL leukemia cells (ranging from 0.2 to $4 \mu \mathrm{M}$ ), Table 1, likely associated with differences in their polarity (clogP values, Table 1) affecting cellular permeability, as assessed in the Caco-2 membrane permeability studies (Supporting Information Table 4). Likewise, compounds 1-10 exhibit different level of selectivity toward MLL-AF9 cells over HM-2 control cell line (reported as selectivity index, SI, ranging from 5 to 32), Table 1. Furthermore, the microsomal stability of these compounds in mouse liver microsomes also varied substantially, Table 1. For example, incorporation of the hydroxyethyl (2) or 1,2propanediol (3-(RS), 3-(R), 3-(S)) substituents at $\mathrm{R}_{1}$ substantially increases polarity (clogP < 3.5 ) and metabolic stability $\left(T_{1 / 2}=18-60 \mathrm{~min}\right)$; however the effect of these compounds on proliferation of the MLL-AF9 cells $\left(\mathrm{GI}_{50}>1 \mu \mathrm{M}\right)$ is weaker than for $\mathbf{1}$, Table 1. Introduction of the methyl (4-(R)) or isopropyl (6) groups at the secondary hydroxyl substantially improves $\mathrm{GI}_{50}$ values (e.g., $\mathrm{GI}_{50}=0.18 \mu \mathrm{M}$ for $\mathbf{6}$ ); however these compounds are metabolically unstable ( $\left.T_{1 / 2}<3 \mathrm{~min}\right)$. Interestingly, $4-(\boldsymbol{R})$ has markedly improved cellular permeability over 3-(RS), Supporting Information Table 4, despite very small difference in their structures, Table 1 . The efflux ratio was $>20$-fold lower for $4-(\boldsymbol{R})$ as compared to 3$(\boldsymbol{R S})$ (Supporting Information Table 4), with both apical to basolateral $(\mathrm{A} \rightarrow \mathrm{B})$ and basolateral to apical (B $\rightarrow$ A) permeability markedly improved for 4-(R). Accordingly, cellular activity of $4-(\boldsymbol{R})$ is almost 10 -fold increased over $3-(\boldsymbol{R S})$ despite similar $\mathrm{IC}_{50}$ values for these compounds, Table 1, emphasizing that increased cellular permeability correlates with cell growth inhibition. The analogue with the acetamide group at $\mathrm{R}_{1}$, compound $\mathbf{7}$, shows cellular activity $\left(\mathrm{GI}_{50}=0.78 \mu \mathrm{M}\right.$ in MLL-AF9 cells) similar to $\mathbf{1}$; however this compound has substantially improved selectivity $(\mathrm{SI}=34)$ and metabolic stability over $\mathbf{1}$, Table 1, and both are likely associated with its higher polarity. Compound 7 also showed low cellular permeability (efflux ratio of $>90$, Supporting Information Table 4) reflected by the modest cellular activity of this compound, Table 1. Finally, similar to the compound with 4methylpyrazole at $\mathrm{R}_{1}(\mathbf{1 0})$, the analogue with 4-methyltriazole (9) has improved cellular activity $\left(\mathrm{GI}_{50}=0.33 \mu \mathrm{M}\right)$, selectivity $(\mathrm{SI}=30)$, microsomal stability, and polarity when compared to $\mathbf{1}$, Table 1 . Therefore, substitutions on the indole nitrogen are very valuable to modulate both cellular activity and druglike properties for this class of menin-MLL inhibitors. Overall, we concluded that hydroxyethyl (present in 2), acetamide (present in 7), 4-methylpyrazole (present in 10), and 4-methyltriazole (present in 9) represent the most valuable substituents at $R_{1}$ due to either superior effect in MLL leukemia cells ( $\mathbf{9}$ and $\mathbf{1 0}$ ) or improved druglike properties (e.g., polarity for $\mathbf{2}$ and $\mathbf{7}$ ). 


\section{Activity and Property Optimization of Analogues Substituted at Positions 3, 4, or 6 of Indole}

Analysis of the crystal structure of the menin-1 complex revealed that carbon at position 3 of the indole ring (position $\mathrm{R}_{2}$, Figure $1 \mathrm{~b}$ ) approaches the backbone of menin, which limits the possibility of substituting at this position. Nevertheless, since this position has not been explored before, we introduced a few small substituents ( $\mathrm{R}_{2}$ substituents) at this position, namely, fluorine (compound 11), amino (compound 12), and methyl (compound 13), Table 2. The inhibitory activity of these compounds was, however, 3- to 4-fold reduced as compared to 1, Table 2, consistent with their relatively weak cellular activity in the MLLAF9 cells. These results support that position 3 on the indole ring of 1 should remain unsubstituted.

We have recently explored several substituents at position 4 of the indole ring $\left(\mathrm{R}_{3}\right.$ substituent, Table 2) and concluded that small hydrophobic groups represent the best substituents at this position, ${ }^{16}$ with the methyl group resulting in $~ 2$-fold improved activity (compound 14, MI-463, $\mathrm{IC}_{50}=15 \mathrm{nM}$, Table 2), likely due to hydrophobic contacts with the aromatic ring of Tyr323, Figure 1a. Here, we completed the series of $\mathrm{R}_{3}$ substituted analogues by incorporating chlorine (compound 15, Table 2) at this position to assess whether it might represent an even more favorable substituent than a methyl group. The in vitro inhibitory activity of $\mathbf{1 5}\left(\mathrm{IC}_{50}=22 \mathrm{nM}\right)$ was slightly improved over $\mathbf{1}$, but the effect on proliferation of the MLL leukemia cells was much weaker $\left(\mathrm{GI}_{50}>1 \mu \mathrm{M}\right)$, Table 2 .

Therefore, we concluded that methyl group represents the best substituent at position 4 of the indole ring.

Finally, we also probed position 6 on the indole ring ( $\mathrm{R}_{4}$ substituents, Table 2$)$, which was not explored previously for substitutions. The crystal structure of the menin-1 complex revealed that this position is partly solvent exposed and that relatively small polar groups could likely enhance inter- and intramolecular interactions (Figure 1a, Figure 1b). Indeed, incorporation of the hydroxyl in compound 17 or methoxy group in compound 18 (MI-336) at $\mathrm{R}_{4}$ resulted in about 1.5 -fold improved inhibitory activity over $\mathbf{1}$, Table 2 . More importantly, these two substituents have led to a significant improvement of growth inhibition in the MLL leukemia cells, in particular compound 17, which showed almost 3fold better $\mathrm{GI}_{50}$ value $\left(\mathrm{GI}_{50}=0.18 \mu \mathrm{M}\right)$ than $\mathbf{1}$, Table 2. Further increase in the size of $\mathrm{R}_{4}$ (e.g., compound $\mathbf{1 9}$ with the ethoxy group) or introduction of fluorine (compound 16) resulted in the reduction of inhibitory activity, Table 2 .

To understand the molecular basis of the activity of these compounds, we determined the crystal structure of $\mathbf{1 8}$ with menin, Supporting Information Table 3. The structure revealed an intramolecular hydrogen bond between the oxygen of the methoxy group and nitrogen in the piperidine ring, which likely stabilizes the conformation of $\mathbf{1 8}$ required for effective binding, Figure 3a. The same interaction is expected for compound $\mathbf{1 7}$ harboring a hydroxyl group at $\mathrm{R}_{4}$. In summary, on the basis of in vitro and cellular activity, we concluded that hydroxyl and methoxy groups represent optimal substituents at $\mathrm{R}_{4}$, and we selected both of them for preparation of multisubstituted derivatives of $\mathbf{1}$ (see below). The metabolic stability and polarity (particularly for $\mathbf{1 8}$ ) still need to be improved for compounds with $\mathrm{R}_{4}$ 
substituents (Table 2), but these liabilities may be compensated by the presence of other substituents on the indole ring (see below).

\section{Activity of Analogues with Multiple Substitutions on Indole Ring}

Having established the optimal substituents at different positions of the indole ring, we then assessed whether simultaneous incorporation of these substituents into the scaffold would provide further improvement of activity and druglike properties. For this purpose, we prepared a number of compounds to probe combinations of the best $\mathrm{R}_{1}$ substituents (hydroxyethyl, acetamide, 4-methylpyrazole, and 4-methyltriazole) with the methyl group as an optimal substituent at $\mathrm{R}_{3}$ and/or two best $\mathrm{R}_{4}$ substituents (hydroxyl or methoxy groups),

Table 3. First, we prepared the $\mathrm{R}_{3}, \mathrm{R}_{4}$ disubstituted analogues (compounds $\mathbf{2 0}$ and $\mathbf{2 1}$ ), Table 3. Although neither compound showed improved in vitro inhibitory activity over $\mathbf{1}$, they demonstrate improved cellular activity in MLL-AF9 cells, Table 3, with compound 21 showing over 5-fold improved cell growth inhibition $\left(\mathrm{GI}_{50}=100 \mathrm{nM}\right)$ as compared to $\mathbf{1}$, Table 3. Interestingly, both $\mathbf{2 0}$ and $\mathbf{2 1}$ showed relatively high to moderate cellular permeability in Caco-2 cells, Supporting Information Table 4, which could contribute to strong growth inhibition in the MLL leukemia cells, Table 3.

The subsequent set of analogues (compounds $22, \mathbf{2 3}, \mathbf{2 4}$ ) contained a hydroxyethyl substituent at $\mathrm{R}_{1}$, a methyl at $\mathrm{R}_{3}$ with $\mathrm{R}_{4}$ remaining either unsubstituted or substituted with hydroxyl or methoxy groups, Table 3. None of these compounds, however, showed substantially increased activity, either in vitro or in MLL leukemia cells, Table 3. Similarly, two analogues with an acetamide group at the indole nitrogen (compounds $\mathbf{2 5}$ and $\mathbf{2 6}$ ) did not demonstrate significantly improved in vitro or cellular activity over $\mathbf{1}$, Table 3 . We next synthesized and tested compounds with aromatic substituents at the indole nitrogen, either 4methylpyrazole (compounds 27-31) or 4-methyltriazole (compounds 32-34), Table 3. Notably, all these compounds showed strong inhibitory activity, with the $\mathrm{IC}_{50}$ values for inhibition of the menin-MLL interaction in the range of 12-24 nM, Table 3, representing an improvement over $\mathbf{1}$. We solved the crystal structure of menin in complex with the most potent 31 (MI-574), which harbors three substituents on the scaffold (Figure 3b). The structure shows that incorporation of several substituents on the indole ring does not affect the binding mode of $\mathbf{3 1}$ to menin as compared to $\mathbf{1}$. The structure also reveals two additional hydrogen bonds, one intramolecular formed by the methoxy group of $\mathbf{3 1}$ and an additional intermolecular between the pyrazole ring and Glu366, Figure 3b, which are likely responsible for 2.6-fold improved activity of this compound over $\mathbf{1}$.

Importantly, simultaneous substitution at multiple sites of indole resulted in compounds with a pronounced effect on the proliferation of MLL leukemia cells, with the most potent compound 27 (MI-538), which showed $\mathrm{GI}_{50}=83 \mathrm{nM}$ in MLL-AF9 cells, representing almost 7-fold improvement over 1, Table 3. Compound 27 binds to menin with low nanomolar affinity $\left(K_{\mathrm{d}}=6.5 \mathrm{nM}\right)$, as assessed by isothermal titration calorimetry (Figure $4 a)$, representing $~ 3.6$-fold improvement in the binding affinity as compared to $\mathbf{1}\left(K_{\mathrm{d}}=23.6\right.$ $\mathrm{nM}) .{ }^{16}$ Therefore, potent cellular activity of $\mathbf{2 7}$ originates from the improved binding affinity to menin and possibly increased cell membrane permeability (e.g., improved permeability over 7 with a similar $\mathrm{IC}_{50}$ value), Supporting Information Table 4. Interestingly, 27, which is 
a double substituted analogue with methylpyrazole at $\mathrm{R}_{1}$ and hydroxyl at $\mathrm{R}_{4}$, has improved cellular activity by 2 - to 3 -fold over monosubstituted compound $\mathbf{1 0}$ or $\mathbf{1 7}$, which harbors only one of these substituents, Tables $1-3$. Further addition of the methyl group at $\mathrm{R}_{3}$ resulting in compound $\mathbf{3 0}$ leads to reduced activity in MLL leukemia cells by more than 2fold, Table 3 . These results demonstrate that simultaneous incorporation of multiple substituents to the scaffold can result in improved cellular activity over monosubstituted analogues; however these substitutions are not fully additive, as cellular activity of triple substituted analogues is not improved over disubstituted analogues of $\mathbf{1}$, Table 3.

\section{Multisubstituted Analogues Demonstrate Favorable Druglike Properties}

In addition to activity, other properties of the analogues of compound 1 were affected by simultaneous introduction of multiple substituents. For example, substantial improvement in selectivity toward MLL leukemia cells, reflected by increase in the SI index, was observed for compounds with multiple substituents on the indole ring, Table 3 . While 1 and the majority of monosubstituted analogues have SI <30, Tables 1 and 2, additional substitutions on the indole led to increased selectivity, resulting in a number of compounds with $\mathrm{SI}>50$, Table 3. For instance, compounds with no substituent at $R_{1}$ but substituted at $R_{3}$ and $R_{4}(20$ and 21), analogues with acetamide at $R_{1}(25$ and 26) as well as 27 with 4-methylpyrazole at $\mathrm{R}_{1}$ and hydroxyl at $\mathrm{R}_{4}$ showed best selectivity, Table 3 . Increase in the selectivity index can be attributed to both the increase in cellular activity toward MLL leukemia cells and a reduced effect in the control cell line HM-2 (e.g., for 25 and 26, Table 3). Although cellular selectivity was rather difficult to predict based upon a particular modification in the scaffold, in general the presence of an additional polar group improves selectivity, Table 3.

Exceptions are compounds $\mathbf{3 3}$ and $\mathbf{3 4}$ due to their weaker effect in MLL-AF9 cells over 32.

Another important property we attempted to optimize was the polarity of these compounds, as the clogP value for the parent compound $\mathbf{1}$ is about 4.3 , implying that it might need further improvement. Indeed, the majority of compounds with multiple substitutions on indole had lower clogP values than $\mathbf{1}$, Table 3, including the compound with the most potent activity in MLL leukemia cells, 27 (clogP = 3.7), which harbors the hydroxyl group at $\mathrm{R}_{4}$. This demonstrates that it is possible to simultaneously improve polarity, cellular activity, and selectivity for this class of menin-MLL inhibitors.

Finally, one liability of the lead compound $\mathbf{1}$ is its relatively poor metabolic stability in the murine liver microsomes $\left(T_{1 / 2}=6.8 \mathrm{~min}\right)$, Table 1 , reflected by unsatisfactory PK profile (see below). By introducing multiple substituents to the indole ring, we were able to substantially improve metabolic stability of analogues of compound $\mathbf{1}$, with a number of compounds showing increase in $T_{1 / 2}$ to over $30 \mathrm{~min}$, Table 3 . This includes compounds 20 , 21, 31, which also demonstrated strong effect on cell proliferation $\left(\mathrm{GI}_{50}\right.$ of $\sim 200 \mathrm{nM}$ or better in MLL-AF9 cells) and good selectivity (SI > 50). The analogue with the most potent cellular activity, compound $\mathbf{2 7}$, has about 2 -fold increase in microsomal stability $\left(T_{1 / 2}=14\right.$ min) over 1, Table 3. Nevertheless, due to its strongest activity in MLL leukemia cells, high selectivity to MLL leukemia cells ( $\mathrm{SI}>100)$, and improved polarity (clogP = 3.7), 27 was chosen for pharmacokinetic studies in mice together with several other compounds. 


\section{Pharmacokinetic Studies of Menin-MLL Inhibitors in Mice}

We selected 27 and several other compounds $(\mathbf{2 0}, \mathbf{2 1}, \mathbf{3 1})$ that showed the best cellular activity in MLL-AF9 cells ( $\left.\mathrm{GI}_{50}<0.2 \mu \mathrm{M}\right)$, high level of selectivity to MLL leukemia cells (SI > 50), and good microsomal stability $\left(T_{1 / 2}>30 \mathrm{~min}\right)$ and performed in vivo pharmacokinetic (PK) studies in mice. The PK studies were also performed for the parent compound 1. Table 4 summarizes the PK parameters for all compounds tested using both intravenous (iv, $15 \mathrm{mg} / \mathrm{kg}$ dose) and oral (po, $30 \mathrm{mg} / \mathrm{kg}$ dose) administration. Importantly, these studies demonstrate substantially improved PK profile for $\mathbf{2 7}$ over $\mathbf{1}$ and other compounds tested, Table 4 . Compound $\mathbf{2 7}$ demonstrated markedly improved exposure (area under the curve, AUC, values), $C_{\max }$ (maximum compound concentration) in the blood plasma, and the lowest value of clearance $\left(\mathrm{Cl}_{\mathrm{obs}}\right)$, Table 4 . The half-life $\left(T_{1 / 2}\right)$ for 27 was reduced as compared to 1 but still remained relatively long ( 1.6 h). To investigate the possible reason for reduced half-life for $\mathbf{2 7}$, we investigated phase II metabolism and found that this compound undergoes glucuronidation, consistent with the presence of the hydroxyl group in the structure (Supporting Information Figure 2). Importantly, 27 has also high oral bioavailability ( $\sim 50 \%$ ), similar to $\mathbf{1}$ and $\mathbf{2 1}$, Table 4 . Out of the other compounds tested in PK studies, $\mathbf{3 1}$ with the trisubstituted 2-cyanoindole ring demonstrated good exposure, but this compound had very poor oral bioavailability, Table 4 . Two other compounds, 20 and 21, with $\mathrm{R}_{3}, \mathrm{R}_{4}$ disubstitutions on the 2-cyanoindole ring did not show substantial improvement in the PK profile over parent compound $\mathbf{1}$, and $\mathbf{2 0}$ had even reduced exposure and increased clearance, Table 4. These results demonstrate that not all substitutions on the 2-cyanoindol ring of 1 result in additive effects on druglike properties, including PK profile, and multiple combinations of substituents need to be tested to identify compounds with the desired activity and properties. These studies also showed a lack of correlation between in vitro microsomal stability and in vivo PK profile, as exemplified for compound $\mathbf{2 0}$ when compared to $\mathbf{1}$ and for $\mathbf{2 7}$ with superior PK but relatively short $T_{1 / 2}$ in mouse liver microsomes, Tables 3 and 4.

\section{Compound 27 Demonstrates On-Target Mechanism of Action in MLL Leukemia Cells}

On the basis of strong effect on proliferation of the MLL-AF9 leukemia cells $\left(\mathrm{GI}_{50}=83\right.$ $\mathrm{nM}$ ), excellent selectivity, and best PK profile (Table 4), 27 was selected for further characterization in MLL leukemia models. First, we assessed the effect of this compound in human MLL leukemia cell lines, MV4;11 and MOLM13, harboring two different MLL translocations (MLL-AF4 and MLL-AF9, respectively), and observed a pronounced inhibition of cell growth $\left(\mathrm{GI}_{50}=170-270 \mathrm{nM}\right)$, Figure $4 \mathrm{~b}$. Importantly, 27 showed no effect (up to $6 \mu \mathrm{M}$ ) on growth of the control cell lines HL-60 and HM-2, which do not harbor MLL translocations, demonstrating good selectivity toward MLL fusion protein transformed cells (Figure $4 b$ ). Inhibition of the menin-MLL interaction is expected to result in the differentiation of MLL leukemia cells and downregulation of MLL fusion target genes. ${ }^{1,14}$ Indeed, we observed pronounced differentiation of MLL-AF9 cells upon treatment with 27 as reflected by cell morphology change (decreased nuclei to cytoplasm ratio, multilobed nuclei and highly vacuolated cytoplasm) as well as marked increase in the expression level of Itgam, a differentiation marker of myeloid cells (Figure 4c,d). Finally, treatment with 27 resulted in strong downregulation of expression of Hoxa9 and Meis 1 genes, the downstream 
targets of MLL fusion proteins required for their leukemogenicity, Figure 4e. About $100 \mathrm{nM}$ 27 was sufficient to reduce by $\sim 50 \%$ Hoxa9 expression in MLL-AF9 cells, and even more pronounced effect was seen on Meis 1 expression, consistent with the strong effect of this compound on proliferation of these cells, Figure $4 \mathrm{~b}$. All these findings further confirm ontarget effects and specific mechanism of action of $\mathbf{2 7}$ menin-MLL inhibitor, suggesting that it represents a valid candidate for in vivo studies in a mouse model of MLL leukemia.

\section{Compound 27 Demonstrates in Vivo Efficacy in a Xenograft Model of MLL Leukemia}

Encouraged by the favorable PK profile as well as the pronounced and specific effect of $\mathbf{2 7}$ in MLL leukemia cells, we selected this compound for in vivo efficacy studies in a mouse xenograft model utilizing MV4;11 human MLL leukemia cells injected subcutaneously into CB17 SCID mice. Treatment with 27 (45 mg/kg, once daily via ip) was initiated when tumor size reached $\sim 100 \mathrm{~mm}^{3}$ and was continued for 2 weeks, Figure 5. Importantly, treatment with 27 resulted in a pronounced, about $80 \%$, reduction in the MV4;11 tumor volume (Figure 5), without causing substantial signs of toxicity reflected by less than $10 \%$ reduction of the body weight (not shown). These results validate that 27 not only is a potent inhibitor of MLL leukemia cell proliferation but can also effectively inhibit the growth of MV4;11 tumors in mice. These data demonstrate a strong potential for this class of menin-MLL inhibitors for further development toward therapeutically useful compounds.

\section{CHEMISTRY}

All inhibitors 1-34 contain the $N$-(piperidin-4-yl)-6-(2,2,2-trifluoroethyl)thieno[2,3d]pyrimidin-4-amine moiety (39) that was synthesized in five steps starting from the 4trifluorobuteraldehyde, Scheme 1, with the key step of Gewald thiophene synthesis. ${ }^{29}$ Condensation of thiophene with triethyl orthoformate gave pyrimidinone 37, which was then converted to 38. Nucleophilic substitution of $\mathbf{3 8}$ with Boc-protected aminopiperidine and subsequent deprotection provided $\mathbf{3 9}$ as hydrochloride salt. The process was optimized to provide high yields of $\mathbf{3 9}$ with no chromatography purification, resulting in overall yield of $45 \%$ over five steps after recrystallization of the final product.

Synthesis of $\mathbf{1}$ and $\mathbf{1 1}$ started from commercially available 5-methylindole-2-carboxylic acid, Scheme 2. The 3-substituted indole was obtained by reaction of 40a with 1-chloromethyl-4fluoro-1,4-diazoniabicyclo[2.2.2] octane bis(tetrafluoroborate) as a source of electrophilic fluorine, providing 40b. The carboxylic acid functional group in 40a and 40b was then converted to nitrile by dehydratation of amide obtained from acid chloride. The Boc protection of indole nitrogen smoothly gave $\mathbf{4 2} \mathbf{a}, \mathbf{b}$ that were subjected to free radical bromination. Bromo derivatives were used for coupling reaction with $\mathbf{3 9}$ followed by Boc group deprotection resulting in $\mathbf{1}$ and $\mathbf{1 1}$, Scheme 2.

For preparation of $\mathbf{7}$ and $\mathbf{8}$, we explored the possibility of introducing substituents on indole nitrogen using compound $\mathbf{1}$ as a substrate, Scheme 2. Indeed, indole $\mathbf{1}$ was deprotonated using $\mathrm{Cs}_{2} \mathrm{CO}_{3}$ as a weak base and directly alkylated with bromoacetamide or 2bromopropionamide to form $\mathbf{7}$ and $\mathbf{8}$, respectively, although in moderate to poor yields. Interestingly, similar conditions with other alkylating reagents did not yield the desired 
products. Therefore, we applied other methodologies to afford compounds $2-\mathbf{6}, \mathbf{9}, \mathbf{1 0}, \mathbf{2 3}-\mathbf{3 4}$ as described below.

Synthesis of 2 was performed according to Scheme 3. Alkylation of indole 41a proceeded efficiently with $\mathrm{NaH}$ as a base producing the hydroxyethyloindole $\mathbf{4 4}$, which was then subjected to free radical bromination, followed by alkylation and deprotection reactions to afford final product 2. Similar approach was employed for synthesis of 1,2-propanediol derivatives of $\mathbf{3}$, where starting materials were either racemic mixture or enantiomerically pure alcohols 45, Scheme 4. After protection of hydroxyl groups in diol $\mathbf{4 5}$ with tertbutyldimethylsilyl ethers (TBS) the resulting intermediates reacted with indole 41a to obtain alkylated compound 46. Further bromination, alkylation, and deprotection reactions provided racemic compound $\mathbf{3}$ as well as its enantiomers, Scheme 4. Synthesis of individual enantiomers of $\mathbf{4}$ required selective methylation of secondary hydroxy group, which was accomplished by removal of both TBS protecting groups from $\mathbf{4 6}$ followed by exclusive protection of primary hydroxyl group with a bulky tert-butyldiphenylsilyl ether (TBDPS) and methylation of a secondary alcohol to afford 47. Subsequently, the bromination, alkylation, and deprotection reactions were performed to yield enantiomerically pure 4-(S) and $4-(R)$.

To synthesize compound $\mathbf{1 2}$, the carboxylic acid $\mathbf{4 8}$ was used as a starting material, Scheme 5. The carboxylic group of $\mathbf{4 8}$ was converted to nitrile via standard amidation and dehydration reactions, followed by reduction of the nitro group with tin chloride (II) to afford 49 in four steps. When $\mathbf{4 9}$ was heated with paraformaldehyde and KCN in the presence of zinc chloride (II), the $N$-cyanomethyl compound $\mathbf{5 0}$ was obtained, which was subjected to Boc protection with 4 equiv of $\mathrm{Boc}_{2} \mathrm{O}$ and simultaneous cyclization to afford 51. Free radical bromination followed by nucleophilic substitution with building block 39 and deprotection resulted in compound $\mathbf{1 2}$, Scheme 5.

Inhibitors bearing methyl groups at position 3 or 4 of indole required different synthetic procedure, in which reductive amination was employed to couple aldehydes $\mathbf{6 0 a - d}$ with 39, Scheme 6. Synthesis of $\mathbf{1 3}$ started from reaction of 2-oxobutyric acid and hydrazine $\mathbf{5 2}$ to produce 53, which after hydrolysis was converted to nitrile via amide to obtain indole derivative 59a. To synthesize aldehydes $\mathbf{6 0 b}-\mathbf{d}$, we used Hemetsberger indole synthesis. ${ }^{30}$ First, acids 56a,b were converted to azidoacrylates $57 \mathbf{a}, \mathbf{b}$. To obtain $\mathbf{5 7}$, direct iodination of phenol $\mathbf{5 4}$ at para position was performed after protection of the hydroxyl group followed by conversion of the intermediate to aldehyde with simultaneous deprotection of phenol, which was then alkylated to yield $\mathbf{5 5}$ and further converted to afford $\mathbf{5 7 c}$. Compounds $\mathbf{5 8 a - c}$ were obtained by refluxing of azidoacrylates $\mathbf{5 7 a}-\mathbf{c}$, resulting in products that precipitated out upon cooling. Subsequently, the 2-cyanoindole compounds 59a-d were obtained after conversion of esters $\mathbf{5 3}$ or $\mathbf{5 8 a - c}$ to nitriles, Scheme 6. Aldehydes 60a,c,d were synthesized by adapting the procedure described by Moyer et al., ${ }^{31}$ while aldehyde $60 \mathrm{~b}$ was prepared by free radical dibromination and hydrolysis of halo derivative in the presence of silver carbonate. Reductive amination with 39 went efficiently to produce 14, 15, 21 with good yields except for $\mathbf{1 3}$ (28\% yield). Subsequently compound $\mathbf{2 0}$ was obtained from $\mathbf{2 1}$ by 
demethylation, while $\mathbf{2 5}$ and $\mathbf{2 6}$ were produced by direct alkylation of $\mathbf{1 4}$ and $\mathbf{2 1}$, respectively.

Compounds 16-19 were synthesized using the procedure shown in Scheme 7. First, the azidoacrylates 62a,b were synthesized from commercially available aldehydes $\mathbf{6 1 a}, \mathbf{b}$. Then, the rhodium trfluoroacetate catalyzed reaction was adapted as a cyclization method, ${ }^{32}$ resulting in 63a,b, which were subsequently converted to nitriles and protected with Boc group. Synthesis of compounds $\mathbf{1 6}$ and $\mathbf{1 8}$ was performed by bromination followed by nucleophilic substitution with $\mathbf{3 9}$ and removal of Boc protecting group. Compound $\mathbf{1 7}$ was obtained after demethylation of $\mathbf{1 8}$ with boron tribromide that was further alkylated with ethyl iodide to get final product 19.

The synthesis of compounds $\mathbf{2 3}, \mathbf{2 4}, \mathbf{2 7}-\mathbf{3 4}$, with multiple substituents on indole ring is depicted in Scheme 8. To prepare alcohol 24, the hydroxyethyl substituent was introduced by alkylation of 60c with trityl protected bromoethanol to afford 69. Pyrazole derivatives 27-31 were synthesized from commercially available ester $\mathbf{6 5}$, which was first protected with trityl group, then reduced to alcohol 66 and transformed to bromide 67 which was used immediately for alkylation of aldehyde $60 \mathrm{a}, 60 \mathrm{c}$, or $\mathbf{6 8 b}$, resulting in $\mathbf{7 0}, \mathbf{7 1}$, or $\mathbf{7 2}$. The triazol moiety was introduced through alkylation of $60 \mathrm{c}$ via click chemistry to obtain $\mathbf{7 3}$. Reductive amination and subsequent deprotection afforded the desired products $\mathbf{2 4}, \mathbf{2 8}, \mathbf{2 9}$, $\mathbf{3 1}$, and $\mathbf{3 4}$, Scheme 8. Finally demethylation of $\mathbf{2 4}, \mathbf{2 8}, \mathbf{3 1}$, and $\mathbf{3 4}$ resulted in 23, 27, 30, and 33, respectively.

\section{CONCLUSIONS}

Development of very potent small molecule inhibitors of protein-protein interactions with optimized druglike properties, including cellular permeability and pharmacokinetic profile, is considered a challenging task due to the increased molecular weight of such compounds often required to achieve high potency. ${ }^{18,20}$ Here, we report optimization of a thienopyrimidine class of compounds, which block the protein-protein interaction between menin and MLL fusion proteins as a potential therapeutic strategy for MLL leukemia. ${ }^{1}$ The difficulty in developing menin-MLL inhibitors partly arises from the large size of the MLL binding site on menin (over $5000 \AA^{3}$ ), ${ }^{12}$ implying that compounds with a relatively large molecular weight might be required to effectively block this PPI, complicating the optimization of their druglike properties.

In this study, we focused on structure-based optimization of our new class of menin-MLL inhibitors, represented by the lead compound $\mathbf{1},{ }^{16}$ with the goal to identify compounds with improved activity and druglike properties and to select compound(s) for characterization in biological experiments. On the basis of the crystal structure of the menin-1 complex, we designed, synthesized, and extensively evaluated series of novel analogues by systematic exploration of substituents on the cyanoindole ring of $\mathbf{1}$. The most potent mono- and multisubstituted analogues demonstrated up to a few fold increase in in vitro activity over the lead compound 1. Furthermore, we discovered that incorporation of substituents at least at two positions of the 2-cyanoindole ring was required to substantially increase both cellular activity and metabolic stability (e.g., compounds 20, 21, 27, 29, 32, Table 3), with 
$\sim 7$-fold increased $\mathrm{GI}_{50}$ value for 27. Interestingly, favorable substituents introduced simultaneously at three positions of the cyanoindole ring did not have an additive effect on cellular activity, and in fact we observed a reduced effect on proliferation of the MLL leukemia cell for such compounds (e.g., trisubstituted compound $\mathbf{3 0}$ has weaker cellular activity than disubstituted compound $\mathbf{2 0}$ or $\mathbf{2 7}$ ) and on their metabolic stability (e.g., compound $\mathbf{3 0}$ as compared to 20). Furthermore, we found that poor cellular permeability (e.g., high efflux ratio) for some of the compounds reported here (e.g., for 7, 3-(RS), and 25) likely leads to the discrepancy in their in vitro and cellular activity. Other effects, including possible variations in the binding kinetics, stability in cells, and solubility of compounds as well as the need to compete with the full length MLL or MLL fusion proteins in cells, might also contribute to the observed differences between in vitro and cellular activity. Overall, these results highlight difficulties in lead optimization process, in particular for inhibitors targeting protein-protein interactions.

Our efforts led to the discovery of several menin-MLL inhibitors with greatly improved potency and druglike properties, out of which 27 displayed (1) strong in vitro inhibition of the menin-MLL interaction, $\mathrm{IC}_{50}=21 \mathrm{nM}$, and the most potent binding affinity to menin $\left(K_{\mathrm{d}}=6.5 \mathrm{nM}\right)$ obtained for small molecule menin-MLL inhibitor reported to date; (2) high potency in inhibiting proliferation of MLL-AF9 transformed cells $\left(\mathrm{GI}_{50}=83 \mathrm{nM}\right)$, demonstrating the best cellular activity observed for any menin-MLL inhibitor reported to date; (3) specific mechanism of action in MLL leukemia cells; (4) superior, over 100-fold, selectivity to the MLL leukemia cells over control cell line; (5) improved polarity as compared to parent compound $\mathbf{1}(\operatorname{cog} \mathrm{P}=3.7$ for 27$)$; (6) greatly improved PK profile, including high oral bioavailability; (7) pronounced efficacy in vivo in mice model of MLL leukemia. Overall, the development of $\mathbf{2 7}$ represents a great achievement for this new class of menin-MLL inhibitors. In fact this compound demonstrates a significant improvement over our recently reported MI-463 and MI-503 ${ }^{16}$ in terms of cellular activity in MLL-AF9 cells, selectivity to MLL leukemia cells, and polarity (clogP value), Tables 2 and 3, making it an excellent candidate for development of a therapeutically useful compound.

Furthermore, 27 has a favorable ligand efficiency index ( $L E=0.28$ ), which is above the average value of 0.24 reported for PPI inhibitors. ${ }^{33}$ Compound 27 discovered in this study constitutes a valuable addition to our menin-MLL inhibitor toolbox to investigate the role of menin-MLL interaction in physiological and disease state and for potential therapeutic applications. Overall, this study demonstrates that property optimization of inhibitors targeting protein-protein interactions represents a complex and multidimensional problem, with an outcome difficult to predict when a particular set of substituents is explored. The difficulties in optimizing PPI inhibitors are at least partly associated with the relatively large molecular weight of these compounds (e.g., most of the compounds reported here have $M_{\mathrm{W}}$ $>500 \mathrm{Da}$ ) and rather high hydrophobicity often required for potent binding to the PPI interfaces. ${ }^{25}$ Extensive medicinal chemistry efforts strongly supported by structure-based design are required to successfully conduct such studies to identify potent PPI inhibitors with optimized physicochemical properties and for advancing such compound to future potential therapeutics. 


\section{EXPERIMENTAL SECTION}

\section{Expression and Purification of Menin}

The expression and purification of menin have been described previously. 9,12

\section{Biochemical Characterization of Menin-MLL Inhibitors}

Inhibition of the menin-MLL interaction by small molecules was assessed by fluorescence polarization (FP) assay using the protocol described previously. 9,14 Briefly, the fluoresceinlabeled MLL (MBM1) peptide at $10 \mathrm{nM}$, menin at $100 \mathrm{nM}$, and varying concentrations of compounds were used for $\mathrm{IC}_{50}$ determination in the FP buffer (50 mM Tris, $\mathrm{pH} 7.5,50 \mathrm{mM}$ $\mathrm{NaCl}, 1 \mathrm{mM}$ DTT). Compounds (5\% final DMSO concentration) were added to the meninMLL peptide complex and incubated for $1 \mathrm{~h}$ before changes in fluorescence polarization were measured using the PHERAstar microplate reader (BMG).

\section{Isothermal Titration Calorimetry}

Menin was extensively dialyzed at $4{ }^{\circ} \mathrm{C}$ against ITC buffer (50 mM phosphate, $\mathrm{pH} 7.5,50$ $\mathrm{mM} \mathrm{NaCl}, 1 \mathrm{mM} \beta$-mercaptoethanol) and degassed prior to measurement. Compound $\mathbf{2 7}$ was dissolved in DMSO and diluted with the ITC buffer to final concentration $(60 \mu \mathrm{M}, 5 \%$ DMSO). Protein solution $(6 \mu \mathrm{M})$ was adjusted to contain 5\% DMSO final concentration. The titrations were performed using a VP-ITC titration calorimetric system (MicroCal) at $25^{\circ} \mathrm{C}$. The calorimetric cell, containing menin, was titrated with 27 injected in $10 \mu \mathrm{L}$ aliquots. Data were analyzed using Origin 7.0 (OriginLab) to obtain $K_{\mathrm{d}}$ and stoichiometry.

\section{Crystallization of Menin Complexes with Small Molecule Inhibitors}

For cocrystallization experiments $2.5 \mathrm{mg} / \mathrm{mL}$ menin was incubated with small molecule inhibitors at 1:3 molar ratio. Crystals were obtained using the sitting drop technique at $10{ }^{\circ} \mathrm{C}$ by applying the procedure described previously. ${ }^{12}$ Prior to data collection, crystals were transferred into a cryo-solution containing 20\% PEG550 MME and flash-frozen in liquid nitrogen.

\section{Crystallographic Data Collection and Structure Determination}

Diffraction data for menin and menin complexes were collected at the 21-ID-D and 21-ID-F beamlines at the Life Sciences Collaborative Access Team at the Advanced Photon Source. Data were processed with HKL-2000. ${ }^{34}$ Structures of the complexes were determined by molecular replacement using MOLREP with the apo-structure of human menin (PDB code 4GPQ) as a search model in molecular replacement. The model was refined using REFMAC,${ }^{35}$ COOT, ${ }^{36}$ and the CCP4 package. ${ }^{37}$ Validation of the structures was performed using MOLPROBITY ${ }^{38}$ and ADIT. ${ }^{39}$ Details of data processing and refinement are summarized in Supporting Information Table 3. Coordinates and structure factors for menin-inhibitor complexes have been deposited in the Protein Data Bank under the following codes: 5DB0 (menin-3-(RS)), 5DB1 (menin-18), 5DB2 (menin-7), and 5DB3 (menin-31). 


\section{Compound Profiling}

Profiling of compound $\mathbf{1}$ was outsourced to the Contract Research Organizations (CROs).

Kinase profiling was performed by Nanosyn (http://www.nanosyn.com/productsandservices/ screening-and-profiling/) and GPCR profiling was performed by Millipore (http:// www.emdmillipore.com/).

\section{Caco-2 Studies}

The Caco-2 membrane permeability studies were performed at Cyprotex (www.cyprotex.com).

\section{Viability Assays}

The MLL-AF9 transformed murine bone marrow cells (BMCs) were prepared as described previously. ${ }^{40}$ MV4;11, MOLM-13, and HL-60 cells were cultured in RPMI-1640 medium with $10 \%$ FBS, $1 \%$ penicillin/streptomycin, and NEAA (nonessential amino acid) solution. For viability assay, MOLM-13 $\left(1 \times 10^{5} / \mathrm{mL}\right)$, MV4;11 $\left(1 \times 10^{5} / \mathrm{mL}\right)$, HL-60 $\left(2 \times 10^{5} / \mathrm{mL}\right)$ human leukemia cells as well as MLL-AF9 and HM-2 murine bone marrow cells ( $2.5 \times$ $10^{4} / \mathrm{mL}$ ) were plated ( $1 \mathrm{~mL} /$ well), treated with compounds or $0.25 \%$ DMSO, and cultured at $37{ }^{\circ} \mathrm{C}$ for 7 days. Media were changed at day 4 with viable cell number restored to the original concentration, and compounds were resupplied. An amount of $100 \mu \mathrm{L}$ of cell suspension was transferred to 96-well plates for each sample in quadruplicates. A Vybrant MTT cell proliferation assay kit (Molecular Probes) was employed. Plates were read for absorbance at $570 \mathrm{~nm}$ using a PHERAstar BMG microplate reader. The experiments were performed 2-3 times in quadruplicate with calculation of mean and standard deviation for each condition.

\section{Real-Time PCR}

Effect of menin-MLL inhibitors on expression level of Hoxa9 and Meis1 was assessed by real-time quantitative PCR (qRT-PCR) using the protocol described previously. ${ }^{12}$

\section{Cytospin/Wright-Giemsa Staining}

Mouse bone marrow cells transduced with MLL-AF9 were plated in 12-well plates ( $1 \mathrm{~mL} /$ well) at an initial concentration of $3 \times 10^{5} / \mathrm{mL}$ cells, treated with compounds or $0.25 \%$ DMSO, and incubated at $37{ }^{\circ} \mathrm{C}$ in a $5 \% \mathrm{CO}_{2}$ incubator. Cytospins were prepared as described previously ${ }^{14}$ at designated time points.

\section{Microsomal Stability Studies}

The metabolic stability was assessed using CD-1 mouse liver microsomes. $1 \mu \mathrm{M}$ compounds were incubated with $1.3 \mathrm{mg} / \mathrm{mL}$ microsomes and $1.7 \mathrm{mM}$ cofactor NADPH in $0.1 \mathrm{M}$ phosphate buffer $(\mathrm{pH}=7.4)$ containing $3.3 \mathrm{mM} \mathrm{MgCl}_{2}$ at $37^{\circ} \mathrm{C}$. The DMSO concentration was less than $0.1 \%$ in the final incubation system. At $0,3,5,10,15,30,45$, and 60 min of incubation, the reactions were stopped by adding 3-fold excess of acetonitrile containing 100 $\mathrm{ng} / \mathrm{mL}$ of internal standard for quantification. The collected fractions were centrifuged at $3000 \mathrm{~g}$ for $20 \mathrm{~min}$ to collect the supernatant for LC-MS/MS analysis, from which the amount of compound remaining was determined. The natural log of the amount of compound 
remaining was plotted against time to determine the disappearance rate and the half-life of tested compounds.

\section{Pharmacokinetic Studies in Mice}

All animal experiments in this study were approved by the University of Michigan Committee on Use and Care of Animals and Unit for Laboratory Animal Medicine (ULAM).

The pharmacokinetics of menin-MLL inhibitors was determined in female C57BL/6 mice following intravenous (iv) dosing at $15 \mathrm{mg} / \mathrm{kg}$ and oral dosing (po) at $30 \mathrm{mg} / \mathrm{kg}$. Compounds were dissolved in the vehicle containing 25\% (v/v) DMSO, 25\% (v/v) PEG-400, and 50\% $(\mathrm{v} / \mathrm{v})$ PBS. Serial blood samples $(50 \mu \mathrm{L})$ were collected over $24 \mathrm{~h}$, centrifuged at $15000 \mathrm{rpm}$ for $10 \mathrm{~min}$, and saved for analysis. Plasma concentrations of the compounds were determined by the LC-MS/MS method developed and validated for this study. The LCMS/MS method consisted of an Agilent 1200 HPLC system, and chromatographic separation of tested compound was achieved using an Agilent Zorbax Extend-C18 column $(5 \mathrm{~cm} \times 2.1 \mathrm{~mm}, 3.5 \mu \mathrm{m}$; Waters). An AB Sciex QTrap 3200 mass spectrometer equipped with an electrospray ionization source (ABI-Sciex, Toronto, Canada) in the positive-ion multiple reaction monitoring (MRM) mode was used for detection. All pharmacokinetic parameters were calculated by noncompartmental methods using WinNonlin, version 3.2 (Pharsight Corporation, Mountain View, CA, USA). Similar procedure was applied for detection of glucuronidation of compound 27 in blood plasma after iv administration of the compound $(15 \mathrm{mg} / \mathrm{kg})$.

\section{In Vivo Efficacy Studies}

Freshly thawed MV4;11 cells (ATCC) were cultured in RPMI-1640 medium with 10\% FBS and penicillin/streptomycin. On the day of injection, cells were resuspended in serum free medium at $1 \times 10^{8}$ cells $/ \mathrm{mL}$ and mixed 1:1 with Matrigel. $5 \times 10^{6}$ cells $(100 \mu \mathrm{L})$ were injected into the right flank of 4- to 6-week-old female BALB/c nude mice. Treatment started when tumor size has reached $\sim 100 \mathrm{~mm}^{3}$. Mice were randomly grouped with each group containing eight mice. Vehicle or compounds were administrated once daily at designated doses using ip injections for 2 weeks. Body weight and tumor sizes were monitored three times a week. The tumor size was calculated as tumor volume $=a b^{2} / 2(a$, long diameter; $b$, short diameter). All animal studies were performed under the Guidelines of the University of Michigan Committee for Use and Care of Animals.

\section{General Chemistry}

All solvents and reagents were used as obtained from commercial sources unless otherwise indicated. The ${ }^{1} \mathrm{H}$ NMR data were taken on Bruker Avance III $600 \mathrm{MHz}$ or Varian MR400. Chemical shifts are reported in ppm relative to tetramethylsilane or residual solvent signal. The mass measurements were determined on a Micromass LCT time-of-flight mass spectrometer using positive mode and electrospray ionization. The exact mass measurements were determined on Agilent Q-TOF time-of-flight mass spectrometer using positive ion mode and electrospray ionization. The melting points were determined on PerkinElmer DSC-7 differential scanning calorimeter and are not corrected. Analytical TLC was 
performed on Merck TLC aluminum plates precoated with $\mathrm{F}_{254}$ silica gel 60 (UV, $254 \mathrm{~nm}$, and iodine). Infrared (IR) spectra were recorded on PerkinElmer FT-IR Spectrum BX on neat powder. The purity analysis of final compounds was determined on Shimadzu Prominence HPLC system (20 series: binary pump, UV/vis at $254 \mathrm{~nm}$, heated column compartment $\left.30^{\circ} \mathrm{C}\right)$, using Restek Ultra C18 $(5 \mu \mathrm{m}) 150 \mathrm{~mm} \times 4.6 \mathrm{~mm}$ column. The solvents were programmed to run at gradient starting $20 \% \mathrm{CH}_{3} \mathrm{CN}$ in water to $80 \%$ during 8 min run. If not indicated, the purity of all final compounds was $>95 \%$ as determined by HPLC via integration of UV spectra at $254 \mathrm{~nm}$. All target compounds 1-34 were tested as hydrochloride salts unless otherwise stated. The standard procedure for $\mathrm{HCl}$ salt formation included dissolving in minimum volume of methanol, addition of 1 equiv of $1 \mathrm{M} \mathrm{HCl}$ in water, and thorough drying. Hydrochloride salts of inhibitors exist as a mixture of rotamers in solution of either DMSO or MeOH with approximate ratio of 10:1; NMR is reported for the major rotamer.

\section{6-(2,2,2-Trifluoroethyl)thieno[2,3-d]pyrimidin-4(3H)-one (37)-4,4,4-}

Trifluorobuteraldehyde $20 \mathrm{~g}$ (158 mmol), cyanoacetamide $13.44 \mathrm{~g}(158 \mathrm{mmol})$, sulfur $5.12 \mathrm{~g}$ $(158 \mathrm{mmol})$, and $27 \mathrm{~mL}$ (190 mmol) of $\mathrm{Et}_{3} \mathrm{~N}$ were stirred in $160 \mathrm{~mL}$ of DMF for $24 \mathrm{~h}$. Solvent was evaporated under reduced pressure. The 2-amino-5-(2,2,2-trifluoroethyl)thiophene-3-carboxamide intermediate was obtained as an oil, which was dissolved in a mixture of $110 \mathrm{~mL}$ of triethyl orthoformate and $80 \mathrm{~mL}$ of acetic acid and refluxed for $4 \mathrm{~h}$ (monitored by TLC, EtOAc). Excess of volatiles was removed under reduced pressure to form an oily solid. $200 \mathrm{~mL}$ of hexane/EtOAc (1:1) was added. After stirring for $30 \mathrm{~min}$ the precipitate was filtered off, washed with $100 \mathrm{~mL}$ of hexane/EtOAc (1:1), and dried on filter affording $28 \mathrm{~g}$ of $37,76 \%$ yield. ${ }^{1} \mathrm{H}$ NMR $\mathrm{CD}_{3} \mathrm{OD}(600 \mathrm{MHz}): \delta 12.6$ (br s, $\left.1 \mathrm{H}\right), 8.14$ (s, $1 \mathrm{H}), 7.42(\mathrm{~s}, 1 \mathrm{H}), 4.07$ (q, $J=11.0 \mathrm{~Hz}, 2 \mathrm{H}) .{ }^{13} \mathrm{C} \mathrm{NMR} \mathrm{CD}_{3} \mathrm{OD}$ (150 MHz): $\delta$ 164.5, 157.01, $146.1,128.4,124.6,123.5,33.6(\mathrm{q}, J=31.5 \mathrm{~Hz})$.

4-Chloro-6-(2,2,2-trifluoroethyl)thieno[2,3-d]pyrimidine (38)—28 g (119 mmol) of 37 was added to $70 \mathrm{~mL}$ of $\mathrm{POCl}_{3}$ with 2 drops of DMF. The heterogeneous mixture was refluxed until all solid dissolved and no starting material was observed on TLC ( $3 \mathrm{~h})$ and then evaporated to remove the excess of phosphorus oxychloride. The residue was quenched carefully with ice and saturated ammonia solution with additional external cooling (CAUTION: highly exothermic reaction). $300 \mathrm{~mL}$ of chloroform was added, and the mixture was transferred in a separatory funnel. Water phase was extracted with additional $100 \mathrm{~mL}$ of chloroform. Combined organic extracts were evaporated (no drying), and the residual material was used in the next step without further purification, $28 \mathrm{~g}$ of $\mathbf{3 8}, 92 \%$ yield. ${ }^{1} \mathrm{H}$ $\mathrm{NMR} \mathrm{CDCl}_{3}$ (600 MHz): $\delta 8.86(\mathrm{~s}, 1 \mathrm{H}), 7.39(\mathrm{~s}, 1 \mathrm{H}), 3.76(\mathrm{q}, J=9.9 \mathrm{~Hz}, 2 \mathrm{H}) .{ }^{13} \mathrm{C}$ NMR $\mathrm{CDCl}_{3}(150 \mathrm{MHz}): \delta 169.0,154.7,153.2,129.9,125.3,123.5,121.3,35.9(\mathrm{q}, J=33.0 \mathrm{~Hz})$.

N-(Piperidin-4-yl)-6-(2,2,2-trifluoroethyl)thieno[2,3- $d]$-pyrimidin-4-amine Hydrochloride (39)—28 g (111 mmol) of 4-chloro-6-(2,2,2-trifluoroethyl)thieno[2,3d]pyrimidine 38, $26.64 \mathrm{~g}$ (133 mmol) of 1-Boc-4-aminopiperidine, and $40 \mathrm{~mL}$ (228 mmol) of $\mathrm{N}, \mathrm{N}$-diisopropylethylamine were stirred under reflux in $400 \mathrm{~mL}$ of IPA for $24 \mathrm{~h}$. Reaction mixture was evaporated to dryness, and then $500 \mathrm{~mL}$ of water was added resulting in precipitation of the crude product. After stirring for $12 \mathrm{~h}$ product was filtered off, washed 
with $1 \mathrm{~L}$ of water, and dried on filter overnight. Solid was transferred to a flask and stirred with $200 \mathrm{~mL}$ of diethyl ether for $12 \mathrm{~h}$. The product was filtered off, washed with $50 \mathrm{~mL}$ of hexane/EtOAc (1:1) and $50 \mathrm{~mL}$ of hexane/EtOAc (3:1). Thorough drying afforded $31 \mathrm{~g}$ of Boc-protected intermediate, $64 \%$ yield. ${ }^{1} \mathrm{H}$ NMR $\mathrm{CD}_{3} \mathrm{CN}(600 \mathrm{MHz}): \delta 8.34(\mathrm{~s}, 1 \mathrm{H}), 7.35$ (s, 1H), 6.16 (br s, 1H), $4.29(\mathrm{~m}, 1 \mathrm{H}), 4.05(\mathrm{~m}, 2 \mathrm{H}), 3.82$ (q, $J=9.9 \mathrm{~Hz}, 2 \mathrm{H}), 2.91(\mathrm{~m}, 2 \mathrm{H})$, $1.97(\mathrm{~m}, 2 \mathrm{H}), 1.47(\mathrm{~m}, 2 \mathrm{H}), 1.44(\mathrm{~s}, 9 \mathrm{H})$. Boc protected intermediate was dissolved in $60 \mathrm{~mL}$ of mixture DCM/MeOH 10:1. $100 \mathrm{~mL}$ of $4 \mathrm{M} \mathrm{HCl}$ solution in dioxane was added, and biphasic mixture was stirred overnight (no staring material was observed on TLC). The reaction mixture was evaporated to dryness, dissolved in $200 \mathrm{~mL}$ of $\mathrm{MeOH}$, and evaporated again forming an oily residue. Oil was dissolved in $100 \mathrm{~mL}$ of $\mathrm{MeOH}$ and stored in freezer overnight. The precipitated product was filtered off, dried on funnel for several hours to afford $27 \mathrm{~g}$ of 39. Free base ${ }^{1} \mathrm{H} \mathrm{NMR} \mathrm{CDCl}_{3}(600 \mathrm{MHz}): \delta 8.47(\mathrm{~s}, 1 \mathrm{H}), 7.13(\mathrm{~s}, 1 \mathrm{H}), 5.32$ (d, $J=7.7 \mathrm{~Hz}, 1 \mathrm{H}), 4.32(\mathrm{~m}, 1 \mathrm{H}), 3.64(\mathrm{q}, J=10 \mathrm{~Hz}, 2 \mathrm{H}), 3.19(\mathrm{~m}, 2 \mathrm{H}), 2.83(\mathrm{~m}, 2 \mathrm{H}), 2.57$ (br s, 1H), $2.14(\mathrm{~m}, 2 \mathrm{H}), 1.55(\mathrm{~m}, 2 \mathrm{H}) .{ }^{13} \mathrm{C} \mathrm{NMR} \mathrm{CDCl}_{3}(150 \mathrm{MHz}): \delta 166.9,156.0,154.3$, $128.1,126.6$ (q, $J=276 \mathrm{~Hz}), 118.7,116.5,48.0,45.3,35.6(\mathrm{q}, J=31.5 \mathrm{~Hz}), 33.1$. ESI MS $\left[\mathrm{M}+\mathrm{H}^{+}\right] \mathrm{m} / \mathrm{z} .317 .2$.

3-Fluoro-5-methyl-1 H-indole-2-carboxylic Acid (40b)-The mixture of $790 \mathrm{mg}(4.5$ $\mathrm{mmol})$ of 40a and $1.76 \mathrm{~g}(5 \mathrm{mmol})$ of 1-chloromethyl-4-fluoro-1,4-

diazoniabicyclo[2.2.2] octane bis-(tetrafluoroborate) was refluxed in $10 \mathrm{~mL}$ of $\mathrm{CH}_{3} \mathrm{CN}$ for 12 h. Mixture was diluted with saturated $\mathrm{NH}_{4} \mathrm{Cl}$ and extracted with chloroform. Organic phase was concentrated and purified using preparative TLC (silica gel, hexane/EtOAc/AcOH (10:1:1) to afford $150 \mathrm{mg}$ of $\mathbf{4 0 b}, 17 \%$ yield. ${ }^{1} \mathrm{H}$ NMR $\mathrm{CDCl}_{3}$ (400 MHz): $\delta 10.03$ (br s, $1 \mathrm{H}), 7.29$ (s, 1H), 7.22 (d, $J=8.4 \mathrm{~Hz}, 1 \mathrm{H}), 7.02$ (d, $J=8.4 \mathrm{~Hz}, 1 \mathrm{H}), 6.35$ (br s, 1H), 2.33 (s, $3 \mathrm{H})$.

5-Methyl-1 H-indole-2-carbonitrile (41a)—A mixture of $0.5 \mathrm{~g}(2.9 \mathrm{mmol})$ of 5methylindole-2-carboxylic acid, $0.25 \mathrm{~mL}$ of thionyl chloride $(3.4 \mathrm{mmol}), 5 \mathrm{~mL}$ of chloroform, and small drop of DMF was refluxed for $2 \mathrm{~h}$. The reaction mixture was cooled to rt, poured into a mixture of $5 \mathrm{~g}$ of ice and $5 \mathrm{~mL}$ of $25 \%$ ammonia solution, and then stirred for $2 \mathrm{~h}$. The precipitated product was filtered off, washed with water, and dried to yield $350 \mathrm{mg}$ of 5-methylindole-2-carboxamide. It was added to $1.5 \mathrm{~g}(9.75 \mathrm{mmol})$ of phosphorus oxychloride and $8 \mathrm{~mL}$ of chloroform refluxed for $2 \mathrm{~h}$. Then cooled solution was poured into $20 \mathrm{~mL}$ of water and stirred for $1 \mathrm{~h}$. After separation the organic layer was dried over sodium sulfate and concentrated. The residue was purified by column chromatography (silica gel, hexane/EtOAc 5:1) to afford $245 \mathrm{mg}$ of 5-methyl- $1 H$-indole-2-carbonitrile (41a), $55 \%$ yield. ${ }^{1} \mathrm{H} \mathrm{NMR} \mathrm{CDCl}_{3}(600 \mathrm{MHz}): \delta 8.61(\mathrm{br} \mathrm{s}, 1 \mathrm{H}), 7.44(\mathrm{~s}, 1 \mathrm{H}), 7.30(\mathrm{~d}, J=8.4 \mathrm{~Hz}$, $1 \mathrm{H}), 7.21(\mathrm{~d}, J=8.4 \mathrm{~Hz}, 1 \mathrm{H}), 7.11(\mathrm{~s}, 1 \mathrm{H}), 2.44(\mathrm{~s}, 3 \mathrm{H}) .{ }^{13} \mathrm{C} \mathrm{NMR} \mathrm{CDCl} 3(150 \mathrm{MHz}): \delta$ 135.3, 131.3, 128.3, 126.5, 121.3, 114.4, 114.0, 111.4, 106.1, 21.4.

3-Fluoro-5-methyl-1 H-indole-2-carbonitrile (41b)-To obtain 41b, a similar procedure as described for $\mathbf{4 1 \mathbf { b }}$ was used but starting with $150 \mathrm{mg}(0.78 \mathrm{mmol})$ of $\mathbf{4 0 b}$. Isolated $60 \mathrm{mg}, 44 \%$ yield. ${ }^{1} \mathrm{H}$ NMR $\mathrm{CDCl}_{3}(600 \mathrm{MHz}): \delta 9.02(\mathrm{br} \mathrm{s}, 1 \mathrm{H}), 7.56(\mathrm{~s}, 1 \mathrm{H}), 7.37$ (d, $J=8.4 \mathrm{~Hz}, 1 \mathrm{H}), 7.24(\mathrm{~d}, J=8.4 \mathrm{~Hz}, 1 \mathrm{H}), 7.15(\mathrm{~s}, 1 \mathrm{H}), 2.46(\mathrm{~s}, 3 \mathrm{H})$. 
tert-Butyl 2-Cyano-5-methyl-1 $\mathbf{H}$-indole-1-carboxylate (42a)-To a solution of 245 $\mathrm{mg}(1.6 \mathrm{mmol})$ of 5 -methyl- $1 H$-indole-2-carbonitrile in $5 \mathrm{~mL}$ of acetonitrile, $0.434 \mathrm{~mL}(1.9$ $\mathrm{mmol})$ of $\mathrm{Boc}_{2} \mathrm{O}$ and $29 \mathrm{mg}(0.24 \mathrm{mmol})$ of DMAP were added and stirred at room temperature for $1 \mathrm{~h}$. The solvent was removed in vacuo, and the resultant crude product was purified by column chromatography (silica gel, hexane/EtOAc, 10:1) to afford $334 \mathrm{mg}$ of 42a, $83 \%$ yield. ${ }^{1} \mathrm{H} \mathrm{NMR} \mathrm{CDCl}_{3}(600 \mathrm{MHz}): \delta 8.10$ (d, $\left.J=8.8 \mathrm{~Hz}, 1 \mathrm{H}\right), 7.39$ (s, $\left.1 \mathrm{H}\right), 7.31$ (d, $J=8.8 \mathrm{~Hz}, 1 \mathrm{H}), 7.26$ (s, $1 \mathrm{H}), 2.45$ (s, 3H), 1.72, (s, 9H). ${ }^{13} \mathrm{C} \mathrm{NMR} \mathrm{CDCl}{ }_{3}(150 \mathrm{MHz}): \delta$ $148.2,134.9,133.8,129.9,121.6,121.2,115.5,113.5,108.8,85.6,28.1,21.2$.

tert-Butyl 2-Cyano-3-fluoro-5-methyl-1 $\boldsymbol{H}$-indole-1-carboxylate (42b)-To obtain 42b, a similar procedure as described for $41 \mathrm{~b}$ was used but starting with $60 \mathrm{mg}(0.34 \mathrm{mmol})$ of $41 \mathrm{~b}$. Isolated $74 \mathrm{mg}, 79 \%$ yield. ${ }^{1} \mathrm{H}$ NMR $\mathrm{CDCl}_{3}(600 \mathrm{MHz}): \delta 9.02(\mathrm{br} \mathrm{s}, 1 \mathrm{H}), 7.56(\mathrm{~s}$, $1 \mathrm{H}), 7.37(\mathrm{~d}, J=8.4 \mathrm{~Hz}, 1 \mathrm{H}), 7.24(\mathrm{~d}, J=8.4 \mathrm{~Hz}, 1 \mathrm{H}), 7.15(\mathrm{~s}, 1 \mathrm{H}), 2.46(\mathrm{~s}, 3 \mathrm{H})$.

\section{5-((4-((6-(2,2,2-Trifluoroethyl)thieno[2,3-d]pyrimidin-4-yl)-amino)piperidin-1-} yl)methyl)-1 $\mathrm{H}$-indole-2-carbonitrile (1)-To a stirred solution of $334 \mathrm{mg}(1.3 \mathrm{mmol})$ of tert-butyl 2-cyano-5-methyl-1 $H$-indole-1-carboxylate in carbon tetrachloride $(5 \mathrm{~mL}), 232$ $\mathrm{mg}(1.3 \mathrm{mmol})$ of $N$-bromosuccinimide and $11 \mathrm{mg}(0.065 \mathrm{mmol})$ of AIBN were added. The mixture was refluxed for $1 \mathrm{~h}$, then cooled, concentrated, and the residue was filtered through silica gel column, using hexane/EtOAc (10:1) to give crude tert-butyl 2-cyano-5bromomethyl-1 $H$-indole-1-carboxylate. $340 \mathrm{mg}(1.06 \mathrm{mmol})$ of tert-butyl 2-cyano-5bromomethyl-1 $H$-indole-1-carboxylate and $375 \mathrm{mg}$ (1.06 mmol) of $N$-(piperidin-4-yl)-6(2,2,2-trifluoroethyl)thieno[2,3- $d$ ] pyrimidin-4-amine hydrochloride were dissolved in $12 \mathrm{~mL}$ of DCM. $820 \mathrm{mg}$ ( $3.2 \mathrm{mmol})$ of DIEA was added to that solution, and reaction mixture was stirred for $18 \mathrm{~h}$. Then reaction mixture was directly loaded on silica gel column and the product was eluted with $\mathrm{DCM}-\mathrm{MeOH}$ (30:1). After evaporation of solvent, the Bocprotected intermediate was dissolved in $10 \mathrm{~mL}$ of $\mathrm{CH}_{3} \mathrm{CN}$ and $1.27 \mathrm{~mL}$ (11 mmol) of $\mathrm{SnCl}_{4}$ was added. The homogeneous reaction mixture was stirred for $1 \mathrm{~h}$, and then all volatiles were removed in vacuo. The residue was quenched with ammonia solution and extracted with ethyl acetate. Combined organic fractions were dried over $\mathrm{MgSO}_{4}$ and concentrated. The residue was purified by column chromatography (silica gel, hexane/EtOAc/ $\mathrm{MeOH}$, 1:1:0.1) to afford $331 \mathrm{mg}$ of 5-((4-((6-(2,2,2-trifluoroethyl)thieno[2,3- $d]$-pyrimidin-4yl)amino)piperidin-1-yl)methyl)-1 $H$-indole-2-carbonitrile, 1 . Its monohydrochloride salt was obtained by adding 1 equiv of $1 \mathrm{M} \mathrm{HCl}$ solution in diethyl ether to a solution of compound in ethanol and thorough drying to afford 1 in $53 \%$ yield. ${ }^{1} \mathrm{H}$ NMR DMSO- $d_{6}(600 \mathrm{MHz}): \delta$ $12.62(\mathrm{~s}, 1 \mathrm{H}), 10.74(\mathrm{br} \mathrm{s}, 1 \mathrm{H}), 8.33(\mathrm{~s}, 1 \mathrm{H}), 8.07$ (d, $J=7 \mathrm{~Hz}, 1 \mathrm{H}), 7.93(\mathrm{~s}, 1 \mathrm{H}), 7.70$ (s, $1 \mathrm{H}), 7.62(\mathrm{~d}, J=12 \mathrm{~Hz}, 1 \mathrm{H}), 7.56(\mathrm{~d}, J=12 \mathrm{~Hz}, 1 \mathrm{H}), 7.45(\mathrm{~s}, 1 \mathrm{H}), 4.36(\mathrm{~s}, 2 \mathrm{H}), 4.30(\mathrm{~m}$, $1 \mathrm{H}), 4.03(\mathrm{q}, J=11 \mathrm{~Hz}, 2 \mathrm{H}), 3.41(\mathrm{~m}, 2 \mathrm{H}), 3.11(\mathrm{~m}, 2 \mathrm{H}), 2.12(\mathrm{~m}, 2 \mathrm{H}), 1.98(\mathrm{~m}, 2 \mathrm{H}) .{ }^{13} \mathrm{C}$ NMR DMSO- $d_{6}(150 \mathrm{MHz}): \delta 165.9,155.7,153.8,137.2,128.4,127.0,125.8,125.4(\mathrm{q}, J=$ $276 \mathrm{~Hz}), 125.4,122.2,121.3,116.1,114.2,113.4,112.5,106.8,59.3,50.4,45.5,33.7$ (q, $J=$ $33 \mathrm{~Hz})$, 28.2. HRMS (ESI): $\left[\mathrm{M}+\mathrm{H}^{+}\right]$calculated 471.1573; found 471.1579 .

3-Fluoro-5-((4-((6-(2,2,2-trifluoroethyl)thieno[2,3- $d]$-pyrimidin-4yl)amino)piperidin-1-yl)methyl)-1 $\boldsymbol{H}$-indole-2-carbonitrile (11)-To prepare 11 , a similar procedure as for $\mathbf{1}$ but starting was applied using $74 \mathrm{mg}(0.26 \mathrm{mmol})$ of $\mathbf{4 2 \mathbf { b }}$. Isolated 
$43 \mathrm{mg}, 34 \%$ yield. ${ }^{1} \mathrm{H}$ NMR $\mathrm{CD}_{3} \mathrm{OD}(600 \mathrm{MHz}): \delta 8.71(\mathrm{~s}, 1 \mathrm{H}), 7.95(\mathrm{~s}, 1 \mathrm{H}), 7.84(\mathrm{~s}, 1 \mathrm{H})$, $7.65(\mathrm{~d}, J=7 \mathrm{~Hz}, 1 \mathrm{H}), 7.53(\mathrm{~d}, J=7 \mathrm{~Hz}, 1 \mathrm{H}), 4.65(\mathrm{~m}, 1 \mathrm{H}), 4.53(\mathrm{~s}, 2 \mathrm{H}), 4.00(\mathrm{q}, J=11 \mathrm{~Hz}$, 2H), $3.65(\mathrm{~m}, 2 \mathrm{H}), 3.34(\mathrm{~m}, 2 \mathrm{H}), 2.37(\mathrm{~m}, 2 \mathrm{H}), 2.15(\mathrm{~m}, 2 \mathrm{H}) .{ }^{13} \mathrm{C}$ NMR $\mathrm{CD}_{3} \mathrm{OD}(150 \mathrm{MHz})$ : $\delta 157.4,153.0,151.2,149.6,136.0,133.0,130.7,125.3(\mathrm{q}, J=276 \mathrm{~Hz}), 123.3,122.8,118.7$, $115.8,115.8,114.7,111.7,94.0,61.6,48.0,35.2(\mathrm{q}, J=33 \mathrm{~Hz}), 29.5$. HRMS (ESI): [M + $\mathrm{H}^{+}$] calculated 489.1479; found 489.1484 .

\section{2-(2-Cyano-5-((4-((6-(2,2,2-trifluoroethyl)thieno[2,3- $d]$-pyrimidin-4- yl)amino)piperidin-1-yl)methyl)-1 $\boldsymbol{H}$-indol-1-yl)-acetamide (7)—760 mg (1.5 mmol)} of 1 (free base) and $207 \mathrm{mg}$ (1.5 mmol) of bromoacetamide were dissolved in $3.6 \mathrm{~mL}$ of dry

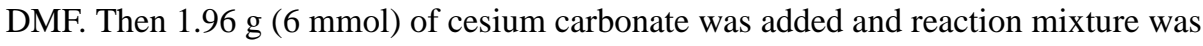
stirred for $4 \mathrm{~h}$. The reaction was quenched with $50 \mathrm{~mL}$ of water and extracted with DCM/ $\mathrm{MeOH}(10: 1)$. Combined organic extracts were evaporated with silica gel and purified by column chromatography (silica gel, DCM/MeOH 10:1). The solvent was evaporated and recrystallized from $\mathrm{MeOH}$ to produce $319 \mathrm{mg}$ of 2-(2-cyano-5-((4-((6- $(2,2,2-$ trifluoroethyl)thieno[2,3- $d$ ]pyrimidin-4-yl)amino)piperidin-1-yl)-methyl)-1 $H$-indol-1yl)acetamide (7), which was converted to hydrochloride salt by dissolving in $5 \mathrm{~mL}$ of $\mathrm{MeOH}$ and adding 1 equiv of $1 \mathrm{M} \mathrm{HCl}$ in water. After evaporation and drying hydrochloride product was obtained as white crystalline material (7), $40 \%$ yield. ${ }^{1} \mathrm{H}$ NMR $\mathrm{CD}_{3} \mathrm{OD}(600 \mathrm{MHz}): \delta$ $8.44(\mathrm{~s}, 1 \mathrm{H}), 7.91(\mathrm{~s}, 1 \mathrm{H}), 7.57(\mathrm{~m}, 2 \mathrm{H}), 7.41(\mathrm{~s}, 1 \mathrm{H}), 5.10(\mathrm{~s}, 2 \mathrm{H}), 4.53(\mathrm{~m}, 2 \mathrm{H}), 4.47(\mathrm{~s}$, $1 \mathrm{H}), 3.89$ (q, $J=10.3 \mathrm{~Hz}, 2 \mathrm{H}), 3.62(\mathrm{~m}, 2 \mathrm{H}), 3.24(\mathrm{~m}, 2 \mathrm{H}), 2.35(\mathrm{~m}, 2 \mathrm{H}), 1.93(\mathrm{~m}, 2 \mathrm{H}) .{ }^{13} \mathrm{C}$ NMR $\mathrm{CD}_{3} \mathrm{OD}(150 \mathrm{MHz}): \delta 171.1,157.7,153.6,140.7,130.8,129.6,128.00,127.1,126.6$ (q, $J=276 \mathrm{~Hz}), 123.5,121.9,118.3,114.8,113.7,113.5,112.6,62.0,52.7,49.6,48.00$, 47.4, 35.5 (q, $J=33 \mathrm{~Hz}$ ), 30.0. HRMS (ESI): [M + $\left.\mathrm{H}^{+}\right]$calculated 528.1788; found 528.1783.

\section{2-(2-Cyano-5-((4-((6-(2,2,2-trifluoroethyl)thieno[2,3- $d]-$ pyrimidin-4- yl)amino)piperidin-1-yl)methyl)-1 $\mathrm{H}$-indol-1-yl)-propanamide (8)—Similar} procedure as for 7 but starting with $50 \mathrm{mg}(0.11 \mathrm{mmol})$ of $\mathbf{1}$. Isolated $16 \mathrm{mg}, 27 \%$ yield. ${ }^{1} \mathrm{H}$ NMR CD $\mathrm{CDD}_{3}$ (600 MHz): $\delta 8.33(\mathrm{~s}, 1 \mathrm{H}), 8.04(\mathrm{~s}, 1 \mathrm{H}), 7.74(\mathrm{~m}, 1 \mathrm{H}), 7.62(\mathrm{~m}, 2 \mathrm{H}), 7.53(\mathrm{~s}$, $1 \mathrm{H}), 5.22(\mathrm{q}, J=9.8 \mathrm{~Hz}, 1 \mathrm{H}), 4.50(\mathrm{~m}, 3 \mathrm{H}), 3.85(\mathrm{q}, J=10.3 \mathrm{~Hz}, 2 \mathrm{H}), 3.62(\mathrm{~m}, 2 \mathrm{H}), 3.26$ $(\mathrm{m}, 2 \mathrm{H}), 2.33(\mathrm{~m}, 2 \mathrm{H}), 2.02(\mathrm{~m}, 2 \mathrm{H}), 1.56(\mathrm{~d}, J=9.8 \mathrm{~Hz}, 3 \mathrm{H}) .{ }^{13} \mathrm{C}$ NMR CD $\mathrm{CD}_{3} \mathrm{OD}(150$ MHz): $\delta 167.0,161.6,157.7,154.8,140.27,139.1,130.0,129.2,128.6,128.2,126.6(\mathrm{q}, J=$ $276 \mathrm{~Hz}), 123.9,122.5,121.8,118.2,113.0,111.0,107.01,54.1,52.8,47.1,35.6$ (q, $J=33$ $\mathrm{Hz}), 30.0,15.8$. HRMS (ESI): $\left[\mathrm{M}+\mathrm{H}^{+}\right]$calculated 542.1944; found 542.1937.

5-Methyl-1-(2-(trityloxy)ethyl)-1 H-indole-2-carbonitrile (44)-2.5 g (19.5 mmol) of 2-bromoethanol, $6 \mathrm{~g}$ (21.5 mmol) of trityl chloride, $95 \mathrm{mg}(0.78 \mathrm{mmol})$ of DMAP, and 4.6 $\mathrm{mL}$ ( $33 \mathrm{mmol}$ ) of triethylamine were stirred in $20 \mathrm{~mL}$ of DCM for $24 \mathrm{~h}$. Reaction mixture was diluted with water, washed with brine, dried over sodium sulfate, and concentrated to produce $6.9 \mathrm{~g}$ of crude 1-tritoxy-2-bromoethane that was used without purification. $468 \mathrm{mg}$ ( $3 \mathrm{mmol}$ ) of 41a was dissolved in $6 \mathrm{~mL}$ of DMF, and $240 \mathrm{mg}(6 \mathrm{mmol})$ of sodium hydride (60\% suspension in oil) was added. After stirring for $5 \mathrm{~min} 1.32 \mathrm{~g}(3.6 \mathrm{mmol})$ of 1-tritoxy-2bromoethane was added and reaction mixture was heated in a sand bath at $60{ }^{\circ} \mathrm{C}$ overnight. Reaction mixture was carefully quenched with ice and extracted with ethyl acetate. Organic 
fractions were evaporated with silica gel purified by column chromatography (silica gel, hexane/EtOAc 5:1) to afford $1.07 \mathrm{~g}$ of $\mathbf{4 4}, 81 \%$ yield. ${ }^{1} \mathrm{H} \mathrm{NMR} \mathrm{CDCl}_{3}(600 \mathrm{MHz}): \delta 8.02$ $(\mathrm{d}, J=8.8 \mathrm{~Hz}, 1 \mathrm{H}), 7.23(\mathrm{~m}, 16 \mathrm{H}), 7.12(\mathrm{~d}, J=8.8 \mathrm{~Hz}, 1 \mathrm{H}), 7.03(\mathrm{~s}, 1 \mathrm{H}), 4.32(\mathrm{t}, J=5.3 \mathrm{~Hz}$, $2 \mathrm{H}), 3.45$ (t, $J=5.3 \mathrm{~Hz}, 2 \mathrm{H}), 2.43$ (s, 3H).

1-(2-Hydroxyethyl)-5-((4-((6-(2,2,2-trifluoroethyl)thieno[2,3- $d]$ pyrimidin-4yl)amino)piperidin-1-yl)methyl)-1 $H$-indole-2-carbonitrile (2)_Bromination and alkylation were carried out as described for $\mathbf{1}$, starting with $1 \mathrm{~g}(2.4 \mathrm{mmol})$ of $\mathbf{4 4}$ to yield 1.6 $\mathrm{g}$ of trityl protected intermediate, which was dissolved in $2 \mathrm{~mL}$ of $\mathrm{MeOH}$, and $0.5 \mathrm{~mL}$ of 12 $\mathrm{M} \mathrm{HCl}$ was added. After 30 min the mixture was quenched with $1 \mathrm{~mL}$ of $30 \% \mathrm{NH}_{3} \cdot \mathrm{H}_{2} \mathrm{O}$, diluted with $50 \mathrm{~mL}$ of DCM, and evaporated with silica gel. The product was purified by column chromatography (silica gel, hexane/EtOAc/MeOH 0.5:1:0.1) to afford $580 \mathrm{mg}, 42 \%$ of pure 2 , that was converted to hydrochloride salt. ${ }^{1} \mathrm{H}$ NMR $\mathrm{CD}_{3} \mathrm{OD}(600 \mathrm{MHz}): \delta 8.75$ (s, 1H), $7.96(\mathrm{~s}, 1 \mathrm{H}), 7.88(\mathrm{~d}, 1 \mathrm{H}, J=8.8 \mathrm{~Hz}), 7.74(\mathrm{~d}, 1 \mathrm{H}, J=8.8 \mathrm{~Hz}), 7.64(\mathrm{~s}, 1 \mathrm{H}), 7.37$ (s, 1H), $4.67(\mathrm{~m}, 1 \mathrm{H}), 4.51(\mathrm{~m}, 3 \mathrm{H}), 4.03(\mathrm{q}, 2 \mathrm{H}, J=10.6 \mathrm{~Hz}), 3.93(\mathrm{~m}, 2 \mathrm{H}), 3.65(\mathrm{~m}, 2 \mathrm{H}), 3.30$ $(\mathrm{m}, 2 \mathrm{H}), 2.36(\mathrm{~m}, 2 \mathrm{H}), 2.18(\mathrm{~m}, 2 \mathrm{H}) .{ }^{13} \mathrm{C}$ NMR CD $\mathrm{CD}_{3} \mathrm{OD}(150 \mathrm{MHz}): \delta 164.9,139.7,133.3$, 129.2, 128.0, 127.1, 127.1, $126.4(\mathrm{q}, J=275 \mathrm{~Hz}), 125.5,123.1,122.8,122.8,118.7,114.2$, 113.1, 113.0, 63.0, 62.0, 52.3, 49.6, 48.5, 35.1 (q, $J=33 \mathrm{~Hz}$ ), 29.5. HRMS (ESI): [M + $\left.\mathrm{H}^{+}\right]$ calculated 515.1835; found 515.1828.

(S)-1-(2,3-Bis((tert-butyldimethylsilyl)oxy)propyl)-5-methyl-1 H-indole-2carbonitrile (46-(S))-331 mg (3 mmol) of (R)-3-chloropropane-1,2-diol and $530 \mathrm{mg}$ (7.8 $\mathrm{mmol}$ ) of imidazole were dissolved in $5 \mathrm{~mL}$ of dry DCM. Then $7.2 \mathrm{~mL}$ of $1 \mathrm{M} \mathrm{TBSCl}$ in DCM was added. Reaction mixture was stirred overnight and then diluted with $20 \mathrm{~mL}$ of water. After separation the organic layer was dried over sodium sulfate and concentrated to produce $850 \mathrm{mg}$ of $(R)$-5-(chloromethyl)-2,2,3,3,8,8,9,9-octamethyl-4,7-dioxa-3,8disiladecane, $84 \%$ yield, which was used in the next step. To a solution of $39 \mathrm{mg}(0.25$ $\mathrm{mmol})$ of 5-methyl- $1 H$-indole-2-carbonitrile in $0.5 \mathrm{~mL}$ of DMF, $15 \mathrm{mg}(0.375 \mathrm{mmol})$ of $\mathrm{NaH}$ (60\% suspension in oil) was added, and mixture was stirred for $30 \mathrm{~min}$. Then $170 \mathrm{mg}$ (0.5 mmol) of ( $R$ )-5-(chloromethyl)-2,2,3,3,8,8,9,9-octamethyl-4,7-dioxa-3,8-disiladecane was added and stirring continued for $24 \mathrm{~h}$. The reaction mixture was diluted with $10 \mathrm{~mL}$ of water and extracted with DCM. Combined organic extracts were dried over sodium sulfate, concentrated, and purified by column chromatography (silica gel, hexane/EtOAc 50:1) to afford $56 \mathrm{mg}$ of $(S)$-1-(2,3-bis((tert-butyldimethylsilyl)oxy)propyl)-5-methyl-1 $H$-indole-2carbonitrile (46-(S)), $49 \%$ yield. ${ }^{1} \mathrm{H} \mathrm{NMR} \mathrm{CDCl}_{3}(600 \mathrm{MHz}): \delta 8.09(\mathrm{~d}, 1 \mathrm{H}, J=8.8 \mathrm{~Hz})$, $7.35(\mathrm{~s}, 1 \mathrm{H}), 7.24(\mathrm{~d}, 1 \mathrm{H}, J=8.8 \mathrm{~Hz}), 7.18(\mathrm{~s}, 1 \mathrm{H}), 4.04(\mathrm{~m}, 1 \mathrm{H}), 3.82(\mathrm{~m}, 1 \mathrm{H}), 3.77(\mathrm{~m}$, $2 \mathrm{H}), 3.68(\mathrm{~m}, 1 \mathrm{H}), 2.43(\mathrm{~s}, 3 \mathrm{H}), 1.08(\mathrm{~m}, 18 \mathrm{H}), 0.26(\mathrm{~m}, 12 \mathrm{H})$.

(S)-1-(3-((tert-Butyldiphenylsilyl)oxy)-2-methoxypropyl)-5-methyl-1 $\boldsymbol{H}$-indole-2carbonitrile (47-(S))-824 mg (1.8 mmol) of 46-(S) was dissolved in $2 \mathrm{~mL}$ of $\mathrm{MeOH}$, and $1 \mathrm{~mL}$ of $4 \mathrm{M} \mathrm{HCl}$ in dioxane was added. After $4 \mathrm{~h}$ TLC indicated no starting material, and reaction mixture was evaporated to dryness. The residue was dissolved in $20 \mathrm{~mL}$ of DCM, and $0.78 \mathrm{~mL}(3 \mathrm{mmol})$ of TBDPSCl was added followed by $218 \mathrm{mg}(3.2 \mathrm{mmol})$ of imidazole. After $1 \mathrm{~h}$ reaction was washed with saturated sodium bicarbonate solution, dried over sodium sulfate, and concentrated to dryness. Crude mixture was dissolved in $4 \mathrm{~mL}$ of 
THF, and $220 \mathrm{mg}$ ( $5.5 \mathrm{mmol})$ of $\mathrm{NaH}$ (60\% suspension in mineral oil) was added. After stirring for $5 \mathrm{~min}, 0.34 \mathrm{~mL}$ ( $5.5 \mathrm{mmol}$ ) of MeI was added. Reaction mixture was carefully quenched with ice after $4 \mathrm{~h}$ and diluted with water. The product was extracted with diethyl ether, organic fractions were evaporated with silica gel, and the product was purified by column chromatography (silica gel, hexane/EtOAc). The product containing fractions were concentrated to afford $95 \mathrm{mg}$ of $47-(S), 11 \%$ yield. ${ }^{1} \mathrm{H}$ NMR $\mathrm{CDCl}_{3}(600 \mathrm{MHz}): \delta 8.11(\mathrm{~d}, J$ $=8.8 \mathrm{~Hz}, 1 \mathrm{H}), 7.71(\mathrm{~m}, 4 \mathrm{H}), 7.45(\mathrm{~m}, 2 \mathrm{H}), 7.38(\mathrm{~m}, 4 \mathrm{H}), 7.34(\mathrm{~s}, 1 \mathrm{H}), 7.24(\mathrm{~d}, J=8.8 \mathrm{~Hz}$, $1 \mathrm{H}), 7.19(\mathrm{~s}, 1 \mathrm{H}), 4.04(\mathrm{~m}, 1 \mathrm{H}), 3.82(\mathrm{~m}, 1 \mathrm{H}), 3.77(\mathrm{~m}, 2 \mathrm{H}), 3.68(\mathrm{~m}, 1 \mathrm{H}), 3.43(\mathrm{~s}, 3 \mathrm{H}), 1.13$ (s, 9H).

(S)-1-(2,3-Dihydroxypropyl)-5-((4-((6-(2,2,2-trifluoroethyl)-thieno[2,3d]pyrimidin-4-yl)amino)piperidin-1-yl)methyl)-1 $\mathrm{H}$-indole-2-carbonitrile (3-(S))To a stirred solution of $55 \mathrm{mg}(0.12 \mathrm{mmol})$ of $47-(S)$ in $0.5 \mathrm{~mL}$ of carbon tetrachloride were added $21.3 \mathrm{mg}$ of $(0.12 \mathrm{mmol}) \mathrm{NBS}$ and $1.1 \mathrm{mg}(0.0065 \mathrm{mmol})$ of AIBN. The mixture was refluxed for $1 \mathrm{~h}$, then cooled, concentrated, and filtered through short silica gel plug using hexane/EtOAc (10:1) to give crude bromide. Bromide was then dissolved in $0.2 \mathrm{~mL}$ of DCM; $36 \mathrm{mg}(0.12 \mathrm{mmol})$ of 39 and $52 \mathrm{mg}(0.4 \mathrm{mmol})$ of DIEA were added to that solution, and reaction mixture was stirred for $18 \mathrm{~h}$. Then reaction mixture was directly purified by column chromatography (silica gel, DCM/MeOH, 30:1). After evaporation of solvent TBSprotected intermediate was dissolved in $0.2 \mathrm{~mL}$ of $\mathrm{MeOH}$ and $0.02 \mathrm{~mL}$ of $12 \mathrm{M} \mathrm{HCl}$ was added. The homogeneous reaction mixture was stirred overnight, and then all volatiles were removed in vacuo. The residue was quenched with concentrated ammonia solution and extracted with ethyl acetate. Combined organic fractions were dried over $\mathrm{MgSO}_{4}$ and concentrated. The residue was purified by column chromatography (silica gel, DCM/MeOH, 20:1) to afford $15.9 \mathrm{mg}$ of 5-((4-((6-(2,2,2-trifluoroethyl)-thieno[2,3- $d$ ]pyrimidin-4yl)amino)piperidin-1-yl)methyl)- $1 H$-indole-2-carbonitrile, 3 -(S), $24 \%$ yield. Its monohydrochloride salt was obtained by adding 1 equiv of $1 \mathrm{M} \mathrm{HCl}$ solution in diethyl ether to a solution of compound in ethanol. 3-(RS) and 3-(R) were synthesized in the same manner but starting with $\mathbf{4 5}-(\boldsymbol{R} S)$ and $45-(S)$, respectively, and analytical data matched those reported for 3-(S). ${ }^{1} \mathrm{H}$ NMR CD ${ }_{3} \mathrm{OD}(600 \mathrm{MHz}): \delta 8.63(\mathrm{~s}, 1 \mathrm{H}), 7.95(\mathrm{~s}, 1 \mathrm{H}), 7.78(\mathrm{~s}, 1 \mathrm{H})$, $7.77(\mathrm{~d}, J=8.6 \mathrm{~Hz}, 1 \mathrm{H}), 7.63(\mathrm{~d}, J=8.6 \mathrm{~Hz}, 1 \mathrm{H}), 7.37(\mathrm{~s}, 1 \mathrm{H}), 4.57(\mathrm{~m}, 1 \mathrm{H}), 4.56(\mathrm{~m}, 1 \mathrm{H})$, $4.50(\mathrm{~s}, 2 \mathrm{H}) 4.37(\mathrm{~m}, 1 \mathrm{H}), 4.04(\mathrm{~m}, 1 \mathrm{H}), 3.99(\mathrm{q}, J=10.3 \mathrm{~Hz}, 2 \mathrm{H}), 3.65(\mathrm{~m}, 2 \mathrm{H}), 3.60(\mathrm{~d}, J=$ $5.5 \mathrm{~Hz}, 2 \mathrm{H}), 3.29(\mathrm{~m}, 2 \mathrm{H}), 2.37(\mathrm{~m}, 2 \mathrm{H}), 2.12(\mathrm{~m}, 2 \mathrm{H}) .{ }^{13} \mathrm{C} \mathrm{NMR} \mathrm{CD}_{3} \mathrm{OD}(150 \mathrm{MHz}): \delta$ $157.5,151.0,139.9,132.3,129.2,127.9,127.4,127.0,126.4$ (q, $J 275 \mathrm{~Hz}), 125.5,123.1$, $122.5,118.6,114.3,114.3,113.4,113.3,72.4,64.9,62.0,52.4,49.8,48.1,35.3$ (q, $J=33$ $\mathrm{Hz})$, 29.6. HRMS (ESI): $\left[\mathrm{M}+\mathrm{H}^{+}\right]$calculated 545.1941; found 545.1950.

(S)-1-(3-Hydroxy-2-methoxypropyl)-5-((4-((6-(2,2,2-trifluoroethyl)thieno[2,3d]pyrimidin-4-yl)amino)piperidin-1-yl)methyl)-1 $H$-indole-2-carbonitrile (4-(S))To obtain 4-(S), a similar procedure was used as for 3-(S) but starting with $95 \mathrm{mg}(0.2$ $\mathrm{mmol})$ of $47-(S)$, and $65 \mathrm{mg}$ of $4-(S)$ was isolated, $58 \%$ yield. $4-(R)$ was synthesized in the same manner but starting with 45-(S). Analytical data matched those reported for $4-(S) .{ }^{1} \mathrm{H}$ NMR CD ${ }_{3} \mathrm{OD}(600 \mathrm{MHz}): \delta 8.44(\mathrm{~s}, 1 \mathrm{H}), 7.92(\mathrm{~s}, 1 \mathrm{H}), 7.74(\mathrm{~d}, J=8.6 \mathrm{~Hz}, 1 \mathrm{H}), 7.62(\mathrm{~s}$, $1 \mathrm{H}), 7.59(\mathrm{~d}, J=8.6 \mathrm{~Hz}, 1 \mathrm{H}), 7.36(\mathrm{~s}, 1 \mathrm{H}), 4.54(\mathrm{~m}, 2 \mathrm{H}), 4.47(\mathrm{~s}, 2 \mathrm{H}), 4.44(\mathrm{~m}, 1 \mathrm{H}), 3.89(\mathrm{q}$, $J=10.3 \mathrm{~Hz}, 2 \mathrm{H}), 3.61(\mathrm{~m}, 5 \mathrm{H}), 3.24(\mathrm{~m}, 2 \mathrm{H}), 3.21(\mathrm{~s}, 3 \mathrm{H}), 2.36(\mathrm{~m}, 2 \mathrm{H}), 2.02(\mathrm{~m}, 2 \mathrm{H}) .{ }^{13} \mathrm{C}$ 
NMR $\mathrm{CD}_{3} \mathrm{OD}(150 \mathrm{MHz}): \delta 157.6,153.4,139.8,130.9,129.3,127.9,126.4$ (q, $\left.J=275 \mathrm{~Hz}\right)$, 123.3, 122.0, 118.34, 114.44, 114.2, 113.4, 113.3, 82.3, 62.0, 61.8, 58.6, 54.8, 52.7, 47.8, 47.5, 35.5 (q, $J=33 \mathrm{~Hz}$ ), 29.9. HRMS (ESI): [M + $\left.\mathrm{H}^{+}\right]$calculated 559.2098; found 559.2091.

2-Amino-5-methylbenzonitrile (49)—A mixture of $905 \mathrm{mg}$ (5 mmol) of $\mathbf{4 8}, 1 \mathrm{~mL}$ of thionyl chloride (12 mmol), $8 \mathrm{~mL}$ of chloroform, and small drop of DMF was refluxed for 2 $\mathrm{h}$. The reaction mixture was cooled to rt, poured into a mixture of $10 \mathrm{~g}$ of ice and $10 \mathrm{~mL}$ of $25 \% \mathrm{NH}_{3} \cdot \mathrm{H}_{2} \mathrm{O}$, and then stirred for $2 \mathrm{~h}$. The precipitated product was filtered off, washed with water, and dried. It was added to $2.6 \mathrm{~g}(17 \mathrm{mmol})$ of phosphorus oxychloride and $8 \mathrm{~mL}$ of chloroform and then refluxed for $2 \mathrm{~h}$. Cooled solution was poured into $20 \mathrm{~mL}$ of water and stirred for $1 \mathrm{~h}$. After separation the organic layer was dried over sodium sulfate and concentrated. The residue was dissolved in $7 \mathrm{~mL}$ of ethanol, and $4.1 \mathrm{~g}$ (22 $\mathrm{mmol}) \mathrm{SnCl}_{2}$ was added. The mixture was refluxed for $1 \mathrm{~h}$ and the silica gel was added followed by $2 \mathrm{~mL}$ of $25 \% \mathrm{NH}_{3} \cdot \mathrm{H}_{2} \mathrm{O}$. All volatiles were removed and residue was purified by column chromatography (silica gel, hexane/EtOAc, 1:1) to afford $120 \mathrm{mg}$ of 49, 18\% yield. HRMS (ESI): $\left[\mathrm{M}+\mathrm{H}^{+}\right]$calculated 133.0760; found 133.0769.

2-((Cyanomethyl)amino)-5-methylbenzonitrile (50)-120 mg (0.93 mmol) of 49, 42 $\mathrm{mg}(1.4 \mathrm{mmol})$ of paraformaldehyde, $506 \mathrm{mg}$ ( $3.7 \mathrm{mmol})$ of $\mathrm{ZnCl}_{2}, 90 \mathrm{mg}(1.4 \mathrm{mmol})$ of potassium cyanide, and $5 \mu \mathrm{L}$ of conc $\mathrm{H}_{2} \mathrm{SO}_{4}$ were dissolved in $2.8 \mathrm{~mL}$ of acetic acid heated to $60{ }^{\circ} \mathrm{C}$ for $6 \mathrm{~h}$. Reaction mixture was diluted with water, neutralized with solid sodium bicarbonate, and extracted with EtOAc. Organic phase was dried over sodium sulfate and evaporated. The residue was purified by column chromatography (silica gel, hexane/EtOAc) to afford $63 \mathrm{mg}$ of $\mathbf{5 0}, 33 \%$ yield. ${ }^{1} \mathrm{H}$ NMR $\mathrm{CDCl}_{3}(600 \mathrm{MHz}): \delta 7.30(\mathrm{~m}, 2 \mathrm{H}), 6.73(\mathrm{~d}, J=$ $8.6 \mathrm{~Hz}, 1 \mathrm{H}), 4.95$ (br s, $1 \mathrm{H}), 4.19$ (d, $J=6.6 \mathrm{~Hz}, 2 \mathrm{H}), 2.27$ (s, 3H).

tert-Butyl 3-((1-Bis(tert-butoxycarbonyl)amino)-2-cyano-5-methyl-1 $\mathrm{H}$-indole-1carboxylate (51)-126 $\mathrm{mg}(0.46 \mathrm{mmol})$ of $\mathbf{5 0}, 22 \mathrm{mg}(0.16 \mathrm{mmol})$ of DMAP were dissolved in $2 \mathrm{~mL}$ of $\mathrm{CH}_{3} \mathrm{CN}$, and $0.42 \mathrm{~mL}(1.84 \mathrm{mmol})$ of $\mathrm{Boc}_{2} \mathrm{O}$ was added. After stirring for $4 \mathrm{~h}$ the reaction mixture was subjected to purification by preparative TLC (silica gel, hexane/EtOAc, 7:1), obtaining $53 \mathrm{mg}$ (25\% yield) of 51, along with $87 \mathrm{mg}$ (25\% yield) of di-Boc intermediate. ${ }^{1} \mathrm{H}$ NMR $\mathrm{CDCl}_{3}(600 \mathrm{MHz}): \delta 8.11(\mathrm{~d}, J=8.6 \mathrm{~Hz}, 1 \mathrm{H}), 7.32(\mathrm{~d}, J=8.6$ $\mathrm{Hz}, 1 \mathrm{H}), 7.22$ (s, 1H), 2.45 (s, 3H), 1.72 (s, 9H), 1.45 (s, 18H).

\section{3-Amino-5-((4-((6-(2,2,2-trifluoroethyl)thieno[2,3- $d]$-pyrimidin-4- yl)amino)piperidin-1-yl)methyl)-1 $\boldsymbol{H}$-indole-2-carbonitrile (12)-Similar procedure was used as for $\mathbf{1}$ but starting with $47 \mathrm{mg}(0.1 \mathrm{mmol})$ of $\mathbf{5 1}$. Isolated $9.2 \mathrm{mg}, 19 \%$ yield. ${ }^{1} \mathrm{H}$ NMR CD $\mathrm{CDD}_{3} \mathrm{O}(600 \mathrm{MHz}): \delta 8.55(\mathrm{~s}, 1 \mathrm{H}), 7.91(\mathrm{~s}, 1 \mathrm{H}), 7.72(\mathrm{~s}, 1 \mathrm{H}), 7.50(\mathrm{~d}, J=9 \mathrm{~Hz}, 1 \mathrm{H})$, $7.39(\mathrm{~d}, J=9 \mathrm{~Hz}, 1 \mathrm{H}), 4.55(\mathrm{~m}, 1 \mathrm{H}), 4.44(\mathrm{~s}, 2 \mathrm{H}), 3.94(\mathrm{q}, J=11 \mathrm{~Hz}, 2 \mathrm{H}), 3.62(\mathrm{~m}, 2 \mathrm{H})$, $3.25(\mathrm{~m}, 2 \mathrm{H}), 2.34(\mathrm{~m}, 2 \mathrm{H}), 2.08(\mathrm{~m}, 2 \mathrm{H}) .{ }^{13} \mathrm{C} \mathrm{NMR} \mathrm{CD}{ }_{3} \mathrm{OD}(150 \mathrm{MHz}): \delta 157.4,151.6$, 138.7, 136.4, 131.9, 130.1, 127.4 (q, $J=276 \mathrm{~Hz}), 124.6,122.4,120.9,120.4,118.5,115.2$, 113.9, 93.0, 62.2, 52.4, 35.4 (q, $J=33 \mathrm{~Hz}), 29.7$. HRMS (ESI): $\left[\mathrm{M}+\mathrm{H}^{+}\right]$calculated 486.1682; found 486.1678 .}


5-Bromo-3-methyl-1 H-indole-2-carboxylic Acid (53)—892 $\mathrm{mg}$ (4 mmol) of $\mathbf{5 3}$ hydrochloride and $408 \mathrm{mg}$ ( $4 \mathrm{mmol})$ of 2-oxobutyric acid were refluxed in $6.5 \mathrm{~mL}$ of absolute ethanol in the presence of $2.4 \mathrm{~g}$ of $\mathrm{H}_{2} \mathrm{SO}_{4}$. After $8 \mathrm{~h}$ the reaction mixture was cooled in the freezer and the precipitate was filtered off to afford $655 \mathrm{mg}$ of $\mathbf{5 3}, 58 \%$ yield. ${ }^{1} \mathrm{H}$ NMR CDCl 3 (600 MHz): $\delta 9.19$ (br s, $\left.1 \mathrm{H}\right), 7.79$ (s, $\left.1 \mathrm{H}\right), 7.38(\mathrm{~d}, J=9.0 \mathrm{~Hz}, 1 \mathrm{H})$, 7.29 (d, $J=9.0 \mathrm{~Hz}, 1 \mathrm{H}), 4.41$ (q, $J=7.3 \mathrm{~Hz}, 2 \mathrm{H}), 2.57$ (s, 3H), 1.43 (t, $J=7.3 \mathrm{~Hz}, 3 \mathrm{H})$.

3-Bromo-4-methoxy-2-methylbenzaldehyde (55) - $5 \mathrm{~g}$ (26 mmol) of 54 was dissolved in $200 \mathrm{~mL}$ of DCM, and $10.4 \mathrm{~mL}$ ( $40 \mathrm{mmol}$ ) of TBDPSCl was added followed by $3.5 \mathrm{~g}$ (52 mmol) of imidazole. After $1 \mathrm{~h}$ reaction was evaporated to dryness and the product was purified by column chromatography (silica gel, hexane/EtOAc, 50:1). Crude intermediate was dissolved in $130 \mathrm{~mL}$ of $\mathrm{CH}_{3} \mathrm{CN} / \mathrm{DCM} 1: 1$, and $9.65 \mathrm{~g} \mathrm{(39} \mathrm{mmol)} \mathrm{of} \mathrm{NIS}$ and $1.99 \mathrm{~mL}$ of TFA were added. The reaction mixture was heated at $50{ }^{\circ} \mathrm{C}$ for $12 \mathrm{~h}$. Then it was diluted with $100 \mathrm{~mL}$ of DCM, washed with saturated $\mathrm{NaHCO}_{3}$ and $\mathrm{Na}_{2} \mathrm{~S}_{2} \mathrm{O}_{3}$, evaporated with silica gel, and purified by column chromatography (silica gel, hexane/ EtOAc, 50:1) to afford $13.5 \mathrm{~g}$ (2-bromo-4-iodo-3-methylphenoxy)(tert-butyl)diphenylsilane. 1H NMR $\mathrm{CDCl}_{3}(600 \mathrm{MHz}): \delta 7.71(\mathrm{~m}, 4 \mathrm{H}), 7.45(\mathrm{~m} \mathrm{2H}), 7.38(\mathrm{~m}, 4 \mathrm{H}), 7.27$ (d, overlaps with solvent residual signal, 1H), $6.02(\mathrm{~d}, J=8.8 \mathrm{~Hz}, 1 \mathrm{H}), 2.68(\mathrm{~s}, 3 \mathrm{H}), 1.13(\mathrm{~s}, 9 \mathrm{H})$.

$11.9 \mathrm{~g}$ (21.5 mmol) of (2-bromo-4-iodo-3-methylphenoxy)(tert-butyl)diphenylsilane was dissolved in dry $86 \mathrm{~mL}$ of THF, the flask was flushed with argon cooled to $-78{ }^{\circ} \mathrm{C}$ (internal temperature, cooling bath EtOAc/ $\mathrm{N}_{2}$ (liq)), and $9.5 \mathrm{~mL}$ of $1.6 \mathrm{M}$ butyllithium $(26 \mathrm{mmol})$ was slowly added to maintain the temperature. After stirring for $0.5 \mathrm{~h}, 5 \mathrm{~mL}$ of DMF ( $75 \mathrm{mmol}$ ) was added dropwise and stirring was continued for $30 \mathrm{~min}$ at the same temperature. Then $100 \mathrm{~mL}$ of $1 \mathrm{M} \mathrm{HCl}$ was added and the reaction mixture was allowed to warm to rt. Organic fraction was evaporated with silica gel and the product was purified by column chromatography (silica gel, hexane/EtOAc, 1:1) to afford $4 \mathrm{~g}$ of 3-bromo-4-hydroxy-2methylbenzaldehyde. It was dissolved in $60 \mathrm{~mL}$ of acetone, and $15.5 \mathrm{~g} \mathrm{(112} \mathrm{mmol)} \mathrm{of}$ $\mathrm{K}_{2} \mathrm{CO}_{3}$ and $13.7 \mathrm{~mL}(222 \mathrm{mmol})$ of methyl iodide were added. The reaction was refluxed overnight, then filtered off and concentrated to afford $4.3 \mathrm{~g}$ of $\mathbf{5 5}, 88 \%$ yield over four steps. ${ }^{1} \mathrm{H}$ NMR $\mathrm{CDCl}_{3}(600 \mathrm{MHz}): \delta 10.08(\mathrm{~s}, 1 \mathrm{H}), 7.81(\mathrm{~s}, 1 \mathrm{H}), 7.68(\mathrm{~d}, J=8.3 \mathrm{~Hz}, 1 \mathrm{H})$, $6.96(\mathrm{~d}, J 8.3=\mathrm{Hz}, 1 \mathrm{H}), 3.22(\mathrm{~s}, 3 \mathrm{H}), 2.75(\mathrm{~s}, 3 \mathrm{H})$.

Methyl 2-Azido-3-(3-bromo-2-methylphenyl)acrylate (57a)-30 g (139 mmol) of 3bromo-2-methylbenzoic acid was dissolved in $180 \mathrm{~mL}$ of THF, cooled to $0{ }^{\circ} \mathrm{C}$, and $9.5 \mathrm{~g}$ $(250 \mathrm{mmol})$ of LAH was added in small portions. After stirring for $3 \mathrm{~h}$ no starting material was observed by TLC. Reaction mixture was carefully quenched with $20 \mathrm{~mL}$ of ethyl acetate and $20 \mathrm{~mL}$ of water. Silica gel was added and mixture was evaporated to dryness and the product was purified by column chromatography (silica gel, hexane/EtOAc, 1:1), resulting in $24 \mathrm{~g}$ of pure alcohol intermediate. ${ }^{1} \mathrm{H} \mathrm{NMR} \mathrm{CDCl}{ }_{3}(600 \mathrm{MHz}): \delta 7.50(\mathrm{~d}, J=8.1 \mathrm{~Hz}, 1 \mathrm{H})$, $7.29(\mathrm{~d}, J=8.1 \mathrm{~Hz}, 1 \mathrm{H}), 7.04(\mathrm{t}, J=8.1 \mathrm{~Hz}, 1 \mathrm{H}), 4.68(\mathrm{~s}, 2 \mathrm{H}), 2.40$ (s, 3H), 1.90 (br s, 1H). ${ }^{13} \mathrm{C} \mathrm{NMR} \mathrm{CDCl}_{3}(150 \mathrm{MHz}): 140.6,135.8,132.0,127.1,126.7,126.1$.

$24 \mathrm{~g} \mathrm{(119} \mathrm{mmol)} \mathrm{of} \mathrm{(3-bromo-2-methylphenyl)methanol} \mathrm{was} \mathrm{dissolved} \mathrm{in} 240 \mathrm{~mL}$ of dichloromethane, and $103 \mathrm{~g}$ (1.2 mol) of manganese(IV) oxide was added. After stirring overnight TLC showed no starting material. Reaction mixture was evaporated with silica gel 
and the product was purified by column chromatography (silica gel, hexane/EtOAc, 10:1) to afford $18.6 \mathrm{~g}$ of pure aldehyde intermediate. ${ }^{1} \mathrm{H} \mathrm{NMR} \mathrm{CDCl}{ }_{3}(600 \mathrm{MHz}): \delta 10.25(\mathrm{~s}, 1 \mathrm{H})$, $7.78(\mathrm{~m}, 2 \mathrm{H}), 7.23(\mathrm{t}, J=7.7 \mathrm{~Hz}, 1 \mathrm{H}), 2.75(\mathrm{~s}, 3 \mathrm{H}) .{ }^{13} \mathrm{C} \mathrm{NMR} \mathrm{CDCl}_{3}(150 \mathrm{MHz}): 191.8$, 137.7, 130.9, 130.2, 127.6, 127.4, 126.8, 18.1.

To the mixture of $18.6 \mathrm{~g}$ (93 mmol) of 3-bromo-2-methylbenzaldehyde and $26.8 \mathrm{~g}$ (233 mmol) of methyl azidoacetate in $130 \mathrm{~mL}$ of $\mathrm{MeOH}$ was added $43 \mathrm{~mL}$ of $5.4 \mathrm{M} \mathrm{MeONa}$ over $30 \mathrm{~min}$ at $-10^{\circ} \mathrm{C}$. After addition the mixture was stirred for additional hour at the same temperature and then transferred to cold room $\left(+4^{\circ} \mathrm{C}\right)$ and stirred overnight. The reaction mixture was then poured in $1 \mathrm{~L}$ mixture of ice and saturated ammonium chloride solution, stirred for $10 \mathrm{~min}$, and filtered off. The solid was washed with plenty of ice cold water and then moved to ambient temperature. After air drying for $1 \mathrm{~h}$ the solid was dissolved in 100 $\mathrm{mL}$ of DCM, dried over magnesium sulfate, and passed through short silica gel plug. Evaporation of solvent gave $21.1 \mathrm{~g}$ of $\mathbf{5 7 a}, 76 \%$ yield, which was used in the next step without further purification. ${ }^{1} \mathrm{H} \mathrm{NMR} \mathrm{CDCl}_{3}(600 \mathrm{MHz}): \delta 7.72(\mathrm{~d}, J=7.7 \mathrm{~Hz}, 1 \mathrm{H}), 7.53(\mathrm{~d}$, $J=7.7 \mathrm{~Hz}, 1 \mathrm{H}), 7.10(\mathrm{~s}, 1 \mathrm{H}), 7.07(\mathrm{t}, J=7.7 \mathrm{~Hz}, 1 \mathrm{H}), 3.93(\mathrm{~s}, 3 \mathrm{H}), 2.42(\mathrm{~s}, 3 \mathrm{H}) .{ }^{13} \mathrm{C} \mathrm{NMR}$ $\mathrm{CDCl}_{3}$ (150 MHz): 163.6, 136.7, 133.9, 133.1, 129.3, 128.8, 126.8, 125.8, 123.6, 53.1, 20.0.

Methyl 2-Azido-3-(2-chloro-3-methylphenyl)acrylate (57b)—Similar procedure was used as for 57a but starting with $10 \mathrm{~g}(57 \mathrm{mmol})$ of $\mathbf{5 6 b}$. Isolated $4.6 \mathrm{~g}, 63 \%$ yield (3 steps). ${ }^{1} \mathrm{H}$ NMR $\mathrm{CDCl}_{3}(600 \mathrm{MHz}): \delta 7.95(\mathrm{~m}, 1 \mathrm{H}), 7.35$ (s, 1H), $7.21(\mathrm{~m}, 2 \mathrm{H}), 3.94(\mathrm{~s}, 3 \mathrm{H})$, $2.40(\mathrm{~s}, 3 \mathrm{H})$.

Methyl 2-Azido-3-(3-bromo-4-methoxy-2-methylphenyl)-acrylate (57c)—Similar procedure was used as the last step for $\mathbf{5 7 a}$ but starting with $4.89 \mathrm{~g}(21 \mathrm{mmol})$ of $\mathbf{5 5}$. Isolated $5.72 \mathrm{~g}, 83 \%$ yield (3 steps). ${ }^{1} \mathrm{H}$ NMR $\mathrm{CDCl}_{3}(600 \mathrm{MHz}): \delta 7.87(\mathrm{~d}, J=8.8 \mathrm{~Hz}, 1 \mathrm{H}), 7.11$ (s, $1 \mathrm{H}), 6.80(\mathrm{~d}, J=8.8 \mathrm{~Hz}, 1 \mathrm{H}), 3.93(\mathrm{~s}, 3 \mathrm{H}), 3.92(\mathrm{~s}, 3 \mathrm{H}), 2.48$ (s, 3H).

Methyl 5-Bromo-4-methyl-1 H-indole-2-carboxylate (58a)-21.1 g (71 mmol) of 57a was dissolved in $700 \mathrm{~mL}$ of xylene. The mixture was refluxed for $10 \mathrm{~min}$. Reaction mixture was cooled to rt and kept at $-20{ }^{\circ} \mathrm{C}$ overnight. The precipitated product was filtered off and dried on funnel to produce $10.0 \mathrm{~g}$ of $\mathbf{5 8 a}, 50 \%$ yield. ${ }^{1} \mathrm{H} \mathrm{NMR} \mathrm{CDCl}_{3}(600 \mathrm{MHz}): \delta 8.98(\mathrm{br}$ s, 1H), 7.44 (d, $J=8.4 \mathrm{~Hz}, 1 \mathrm{H}), 7.24$ (s, 1H), 7.14 (d, $J=8.4 \mathrm{~Hz}, 1 \mathrm{H}), 3.96$ (s, 3H), 2.60 (s, $3 \mathrm{H}) .{ }^{13} \mathrm{C} \mathrm{NMR} \mathrm{CDCl}_{3}(150 \mathrm{MHz}): \delta 162.1,135.4,131.6,129.5,129.0,127.4,115.9,110.8$, 107.7, 52.2, 19.0.

Methyl 4-Chloro-5-methyl-1 $\mathbf{H}$-indole-2-carboxylate (58b)-Similar procedure was used as for $\mathbf{5 7 a}$ but starting with $4.6 \mathrm{~g}(18 \mathrm{mmol})$ of $\mathbf{5 7 b}$. Isolated $3.0 \mathrm{~g}, 74 \%$ yield. ${ }^{1} \mathrm{H}$ NMR $\mathrm{CDCl}_{3}(600 \mathrm{MHz}): \delta 9.01$ (br s, $\left.1 \mathrm{H}\right), 7.28(\mathrm{~s}, 1 \mathrm{H}), 7.23(\mathrm{~d}, J=8.4 \mathrm{~Hz}, 1 \mathrm{H}), 7.17$ (d, $J=8.4$ $\mathrm{Hz}, 1 \mathrm{H}), 3.96$ (s, 3H), 2.46 (s, 3H).

Methyl 5-Bromo-6-methoxy-4-methyl-1 H-indole-2-carboxylate (58c)—Similar procedure was used as for $\mathbf{5 7 a}$ but starting with $5.7 \mathrm{~g} \mathrm{(17} \mathrm{mmol)} \mathrm{of} \mathrm{57c.} \mathrm{Isolated} 4.2 \mathrm{~g}, 81 \%$ yield. ${ }^{1} \mathrm{H}$ NMR $\mathrm{CDCl}_{3}(600 \mathrm{MHz}): \delta 8.83(\mathrm{br}, 1 \mathrm{H}), 7.20(\mathrm{~s}, 1 \mathrm{H}), 6.74(\mathrm{~s}, 1 \mathrm{H}), 3.93(\mathrm{~s}, 6 \mathrm{H})$, $2.62(\mathrm{~s}, 3 \mathrm{H})$. 
5-Bromo-4-methyl-1 $\boldsymbol{H}$-indole-2-carbonitrile (59a)-10.0 g (38 mmol) of 58a was refluxed in a solution of $10.6 \mathrm{~g}(190 \mathrm{mmol})$ of $\mathrm{KOH}$ in $130 \mathrm{~mL}$ of methanol for $1 \mathrm{~h}$. Reaction mixture was then concentrated and acidified with $12 \mathrm{M} \mathrm{HCl}$ in water. Precipitated product was filtered off. After drying the 5-bromo-4-methyl- $1 H$-indole-2-carboxylic acid was added to solution of $6.5 \mathrm{~mL}$ ( $76 \mathrm{mmol}$ ) of oxalyl chloride in $200 \mathrm{~mL}$ of dichloromethane with $0.6 \mathrm{~mL}$ of DMF. After stirring for $1 \mathrm{~h}$ reaction mixture was cooled in ice-water bath and $40 \mathrm{~mL}$ of conc ammonia solution in water was added dropwise. The heterogeneous mixture was stirred for another $3 \mathrm{~h}$ and filtered off to obtain amide. A mixture of 5-bromo-4-methyl-1 $H$-indole-2-carboxamide from previous step, $36 \mathrm{~mL}$ ( $380 \mathrm{mmol}$ ) of phosphorus oxychloride, and $120 \mathrm{~mL}$ of chloroform was refluxed for $5 \mathrm{~h}$. Then reaction mixture was evaporated to dryness and quenched with ice and conc ammonia solution in water (about $40 \mathrm{~mL}$ ). The formed precipitate was filtered off, washed with water, and dissolved in $100 \mathrm{~mL}$ of THF. The solution was evaporated with silica gel and the product was purified by column chromatography (silica gel, hexane/EtOAc, 2:1), affording $7.4 \mathrm{~g}$ of pure nitrile 59a, $82 \%$ yield. ${ }^{1} \mathrm{H}$ NMR $\left(\mathrm{CD}_{3}\right)_{2} \mathrm{CO}(600 \mathrm{MHz}): \delta 11.42(\mathrm{br} \mathrm{s}, 1 \mathrm{H}), 7.49(\mathrm{~d}, J=$ $8.8 \mathrm{~Hz}, 1 \mathrm{H}), 7.42(\mathrm{~s}, 1 \mathrm{H}), 7.32(\mathrm{~d}, J=8.8 \mathrm{~Hz}, 1 \mathrm{H}), 2.59(\mathrm{~s}, 3 \mathrm{H}) .{ }^{13} \mathrm{C} \mathrm{NMR}\left(\mathrm{CD}_{3}\right)_{2} \mathrm{CO}(150$ MHz): $\delta 137.5,132.0,131.0,129.3,117.2,114.9,113.7,113.0,108.5,19.6$.

4-Chloro-5-methyl-1 $\mathrm{H}$-indole-2-carbonitrile (59b) - Similar procedure was used as for 59a but starting with $3.0 \mathrm{~g}(13 \mathrm{mmol})$ of $\mathbf{5 8 b}$. Isolated $1.5 \mathrm{~g}, 60 \%$ yield. ${ }^{1} \mathrm{H} \mathrm{NMR} \mathrm{CDCl}_{3}$ (600 MHz): $\delta 8.79(\mathrm{br} \mathrm{s}, 1 \mathrm{H}), 7.42(\mathrm{~d}, 1 \mathrm{H}, J 8.4 \mathrm{~Hz}), 7.34(\mathrm{~s}, 1 \mathrm{H}), 7.28(\mathrm{~d}, 1 \mathrm{H}, J 8.4 \mathrm{~Hz})$, $2.61(\mathrm{~s}, 3 \mathrm{H})$.

5-Bromo-6-methoxy-4-methyl-1 $\boldsymbol{H}$-indole-2-carbonitrile (59c)-Similar procedure was used as for 59a but starting with $4.2 \mathrm{~g}(13 \mathrm{mmol})$ of 58c. Isolated $3.3 \mathrm{~g}, 96 \%$ yield. ${ }^{1} \mathrm{H}$ NMR $\left(\mathrm{CD}_{3}\right)_{2} \mathrm{CO}(600 \mathrm{MHz}): \delta 10.24$ (br s, 1H), $7.13(\mathrm{~s}, 1 \mathrm{H}), 6.80(\mathrm{~s}, 1 \mathrm{H}), 3.93(\mathrm{~s}, 3 \mathrm{H})$, $2.61(\mathrm{~s}, 3 \mathrm{H})$.

5-Bromo-3-methyl-1 $\mathrm{H}$-indole-2-carbonitrile (59d) - Similar procedure was used as for 59a but starting with $655 \mathrm{mg}(2.32 \mathrm{mmol})$ of $\mathbf{5 3}$. Isolated $300 \mathrm{mg}, 56 \%$ yield. ${ }^{1} \mathrm{H}$ NMR $\mathrm{CDCl}_{3}(600 \mathrm{MHz}): \delta 9.35$ (br s, $\left.1 \mathrm{H}\right), 7.81(\mathrm{~s}, 1 \mathrm{H}), 7.39(\mathrm{~d}, J=9.0 \mathrm{~Hz}, 1 \mathrm{H}), 7.32(\mathrm{~d}, J 9.0=$ $\mathrm{Hz}, 1 \mathrm{H}), 2.62$ (s, 3H).

5-Formyl-4-methyl-1H-indole-2-carbonitrile (60a)-2.35 g (10 mmol) of 5-bromo-4methyl- $1 H$-indole-2-carbonitrile 59a was dissolved in $100 \mathrm{~mL}$ of THF. The flask was flushed with argon, and $3.2 \mathrm{~g}$ ( $24 \mathrm{mmol}$ ) of potassium hydride was added (30\% suspension in oil). After stirring for $5 \mathrm{~min}$ the reaction mixture was cooled to $-90{ }^{\circ} \mathrm{C}$ (internal temperature with probe, ethanol/ $\mathrm{N}_{2}$ (liq)) and $11.8 \mathrm{~mL}$ of tert-butyllithium $(20 \mathrm{mmol})$ was slowly added to maintain the temperature at the range -95 to $-90^{\circ} \mathrm{C}$. After stirring for $1 \mathrm{~h}$ $3.8 \mathrm{~mL}$ (50 mmol) of DMF was added dropwise and reaction mixture was allowed to warm to $-70{ }^{\circ} \mathrm{C}$ and kept $30 \mathrm{~min}$ at this temperature. The reaction mixture was quenched with 2.9 $\mathrm{mL}(50 \mathrm{mmol})$ of acetic acid and warmed to rt. After addition of $100 \mathrm{~mL}$ of brine organic phase was separated, evaporated with silica gel and the product was purified by column chromatography (silica gel, hexane/THF, 1:1). After evaporation, $1.11 \mathrm{~g}$ of pure aldehyde 60a was obtained, $60 \%$ yield. ${ }^{1} \mathrm{H}$ NMR $\mathrm{CD}_{3} \mathrm{CN}$ (600 MHz): $\delta 10.39$ (s, $\left.1 \mathrm{H}\right), 7.82$ (d, $J=8.4$ 
$\mathrm{Hz}, 1 \mathrm{H}), 7.51(\mathrm{~s}, 1 \mathrm{H}), 7.43(\mathrm{~d}, J=8.4 \mathrm{~Hz}, 1 \mathrm{H}), 2.86(\mathrm{~s}, 3 \mathrm{H}) .{ }^{13} \mathrm{C} \mathrm{NMR} \mathrm{CD} \mathrm{CN}_{3}(150 \mathrm{MHz})$ : $\delta 191.2,138.9,137.2,127.3,126.9,126.6,113.7,113.1,110.0,107.2,13.4$.

4-Chloro-5-formyl-1 $\boldsymbol{H}$-indole-2-carbonitrile (60b)-To a solution of $702 \mathrm{mg}$ (3.7 $\mathrm{mmol})$ of $\mathbf{5 9 b}$ in $5 \mathrm{~mL}$ of acetonitrile, $1.0 \mathrm{~mL}(4.4 \mathrm{mmol})$ of $\mathrm{Boc}_{2} \mathrm{O}$ and $45 \mathrm{mg}(0.37 \mathrm{mmol})$ of DMAP were added and stirred at room temperature for $1 \mathrm{~h}$. The solvent was removed in vacuo, and the crude product was filtered through silica gel column using hexane/EtOAc $(10: 1)$ as an eluent to afford $1.03 \mathrm{~g}$ of Boc-protected intermediate, $96 \%$ yield. The intermediate $(3.5 \mathrm{mmol})$ was dissolved in $35 \mathrm{~mL}$ of carbon tetrachloride, and $1.45 \mathrm{~g}(8.2$ mmol) of $N$-bromosuccinimide and $60 \mathrm{mg}(0.37 \mathrm{mmol})$ of AIBN were added. The mixture was refluxed for $2 \mathrm{~h}$, then cooled to room temperature and evaporated to dryness. Then it was dissolved in $70 \mathrm{~mL}$ of acetone/water mixture (1:1) and $1.17 \mathrm{~g} \mathrm{(4.2} \mathrm{mmol)} \mathrm{of} \mathrm{silver}$ carbonate was added. The mixture was stirred for $24 \mathrm{~h}$, then concentrated and diluted with $50 \mathrm{~mL}$ of EtOAc. Mixture was filtered off through Celite, organic phase was evaporated with silica gel, and the product was purified by column chromatography (silica gel, hexane/DCM, 1:2) to afford $641 \mathrm{mg}$ of Boc-protected intermediate $\mathbf{6 0 b}, 60 \%$ yield. It was then dissolved in $4 \mathrm{~mL}$ of DCM/TFA (1:1) and stirred for $1 \mathrm{~h}$. The mixture was evaporated and partitioned in EtOAc and saturated with $\mathrm{NaHCO}_{3}$ solution. Organic phase was evaporated with silica gel and the product was purified by column chromatography (silica gel, DCM:acetone, 40:1) to afford $330 \mathrm{mg}$ of $\mathbf{6 0 b}, 81 \% .{ }^{1} \mathrm{H}$ NMR $\mathrm{CD}_{3} \mathrm{CN}(600 \mathrm{MHz}): \delta 11.63$ (br s, $\left.1 \mathrm{H}\right), 10.56(\mathrm{~s}, 1 \mathrm{H})$, $7.92(\mathrm{~d}, J=8.6 \mathrm{~Hz}, 1 \mathrm{H}), 7.47$ (d, $J=8.6 \mathrm{~Hz}, 1 \mathrm{H}), 7.43(\mathrm{~s}, 1 \mathrm{H})$.

5-Formyl-6-methoxy-4-methyl-1 $\boldsymbol{H}$-indole-2-carbonitrile (60c)-Similar procedure

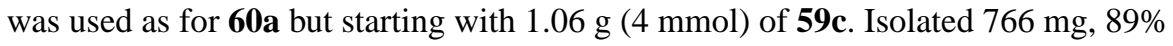
yield. ${ }^{1} \mathrm{H}$ NMR $\mathrm{CD}_{3} \mathrm{CN}(600 \mathrm{MHz}): \delta 10.57$ (s, 1H), 9.89 (br s, 1H), $7.24(\mathrm{~s}, 1 \mathrm{H}), 6.92$ (s, $1 \mathrm{H}), 3.90$ (s, 3H), 2.71 (s, 3H).

5-Formyl-3-methyl-1 $\mathbf{H}$-indole-2-carbonitrile (60d)—Similar procedure was used as for 60a but starting with $93 \mathrm{mg}(0.4 \mathrm{mmol})$ of $59 \mathrm{~d}$. Isolated $23 \mathrm{mg}, 32 \%$ yield. ${ }^{1} \mathrm{H}$ NMR $\mathrm{CD}_{3} \mathrm{CN}(600 \mathrm{MHz}): \delta 10.96$ (br s, $\left.1 \mathrm{H}\right), 10.06(\mathrm{~s}, 1 \mathrm{H}), 8.19(\mathrm{~s}, 1 \mathrm{H}), 7.90(\mathrm{~d}, J=8.8 \mathrm{~Hz}, 1 \mathrm{H})$, $7.53(\mathrm{~d}, J=8.8 \mathrm{~Hz}, 1 \mathrm{H}), 2.57$ (s, 3H).

\section{4-Methyl-5-((4-((6-(2,2,2-trifluoroethyl)thieno[2,3- $d]$-pyrimidin-4- yl)amino)piperidin-1-yl)methyl)-1 H-indole-2-carbonitrile (14)-800 mg (4.35} mmol) of 5-formyl-4-methyl-1 $H$-indole-2-carbonitrile, $1.83 \mathrm{~g}$ (5.22 mmol) of $\mathrm{N}$ (piperidin-4-yl)-6-(2,2,2-trifluoroethyl)thieno[2,3- $d$ ]pyrimidin-4-amine hydrochloride, and $1.2 \mathrm{~mL}(8.7 \mathrm{mmol})$ of triethylamine were mixed in $43 \mathrm{~mL}$ of dry dichloromethane. $1.84 \mathrm{~g}$ $(8.7 \mathrm{mmol})$ of sodium triacetoxyborohydride was added to it in one portion. After stirring overnight TLC showed no presence of starting material. The reaction mixture was transferred to a separatory funnel and washed with $50 \mathrm{~mL}$ of $1 \mathrm{M} \mathrm{NaOH}$. Organic phase was evaporated with silica gel and the product was purified by column chromatography (silica gel, $\mathrm{DCM} / \mathrm{MeOH} / \mathrm{NH}_{3}(\mathrm{aq})$ 40:1:0.1 to 15:1:0.1). Evaporation of solvent gave $2.08 \mathrm{~g}$ of oily product, which was dissolved in $5 \mathrm{~mL}$ of diethyl ether and crystallized upon standing. The product was filtered off, washed with additional $10 \mathrm{~mL}$ of ether, and thoroughly dried to afford $1.95 \mathrm{~g}$ of product, $93 \%$ yield. The compound was converted to hydrochloride salt by 
dissolving in $5 \mathrm{~mL}$ of $\mathrm{MeOH}$ followed by addition of $4.4 \mathrm{~mL}$ of $1 \mathrm{M} \mathrm{HCl}$ in water (4.4 mmol) and drying to afford $14 .{ }^{1} \mathrm{H}$ NMR $\mathrm{CD}_{3} \mathrm{OD}(600 \mathrm{MHz}): \delta 8.35(\mathrm{~s}, 1 \mathrm{H}), 7.53(\mathrm{br} \mathrm{s}$, $1 \mathrm{H}), 7.48(\mathrm{~d}, J=8.4 \mathrm{~Hz}, 1 \mathrm{H}), 7.41(\mathrm{~d}, J=8.4 \mathrm{~Hz}, 1 \mathrm{H}), 7.40(\mathrm{~m}, 2 \mathrm{H}), 4.51(\mathrm{~s}, 2 \mathrm{H}), 4.46(\mathrm{~m}$, $1 \mathrm{H}), 3.86(\mathrm{q}, J=10.5 \mathrm{~Hz}, 2 \mathrm{H}), 3.60(\mathrm{~m}, 2 \mathrm{H}), 3.33(\mathrm{~m}, 2 \mathrm{H}), 2.70(\mathrm{~s}, 3 \mathrm{H}), 2.33(\mathrm{~m}, 2 \mathrm{H}), 1.95$ $(\mathrm{m}, 2 \mathrm{H}) .{ }^{13} \mathrm{C}$ NMR CD $3 \mathrm{OD}(150 \mathrm{MHz}): \delta 167.1,157.7,154.9,138.9,134.5,130.4,130.0$, 128.9, 126.6 (q, $J=275 \mathrm{~Hz}), 121.7,118.2,114.9,113.6,111.7,108.4,59.1,52.9,49.6$, 47.2, 35.7 (q, $J=32 \mathrm{~Hz}), 30.1,15.9$. HRMS (ESI): $\left[\mathrm{M}+\mathrm{H}^{+}\right]$calculated 485.1730; found 485.1733 .

\section{3-Methyl-5-((4-((6-(2,2,2-trifluoroethyl)thieno[2,3-d]-pyrimidin-4-} yl)amino)piperidin-1-yl)methyl)-1 $\boldsymbol{H}$-indole-2-carbonitrile (13)-Similar procedure was used as for 14 but starting with $29 \mathrm{mg}(0.16 \mathrm{mmol})$ of $\mathbf{6 0 d}$. Isolated $21 \mathrm{mg}, 28 \%$ yield. ${ }^{1} \mathrm{H}$ NMR $\mathrm{CD}_{3} \mathrm{OD}(600 \mathrm{MHz}): \delta 8.36(\mathrm{~s}, 1 \mathrm{H}), 7.89(\mathrm{~s}, 1 \mathrm{H}), 7.55(\mathrm{~s}, 1 \mathrm{H}), 7.52(\mathrm{~m}, 2 \mathrm{H})$, $4.47(\mathrm{~s}, 2 \mathrm{H}), 4.45(\mathrm{~m}, 1 \mathrm{H}), 3.86(\mathrm{q}, J=10.5 \mathrm{~Hz}, 2 \mathrm{H}), 3.61(\mathrm{~m}, 2 \mathrm{H}), 3.24(\mathrm{~m}, 2 \mathrm{H}), 2.51(\mathrm{~s}$, $3 \mathrm{H}), 2.35(\mathrm{~m}, 2 \mathrm{H}), 1.98(\mathrm{~m}, 2 \mathrm{H}) .{ }^{13} \mathrm{C} \mathrm{NMR} \mathrm{CD}_{3} \mathrm{OD}(150 \mathrm{MHz}): \delta 164.8,156.1,153.0$, $137.7,128.7,127.8,126.5,125.0(\mathrm{q}, J=275 \mathrm{~Hz}), 123.7,123.5,120.7,120.3,116.7,113.0$, $112.4,106.0,60.7,51.2,45.7,35.4(\mathrm{q}, J=32 \mathrm{~Hz}), 28.5,7.9$. HRMS (ESI): $\left[\mathrm{M}+\mathrm{H}^{+}\right]$ calculated 485.1730 ; found 485.1724 .

\section{4-Chloro-5-((4-((6-(2,2,2-trifluoroethyl)thieno[2,3-d]-pyrimidin-4-} yl)amino)piperidin-1-yl)methyl)-1 $\boldsymbol{H}$-indole-2-carbonitrile (15)-Similar procedure was used as for 14 but starting with $29 \mathrm{mg}(0.16 \mathrm{mmol})$ of $\mathbf{6 0 d}$. Isolated $21 \mathrm{mg}, 28 \%$ yield. ${ }^{1} \mathrm{H}$ NMR $\mathrm{CD}_{3} \mathrm{OD}(600 \mathrm{MHz}): \delta 8.42(\mathrm{~s}, 1 \mathrm{H}), 7.86(\mathrm{~s}, 1 \mathrm{H}), 7.59(\mathrm{~s}, 1 \mathrm{H}), 7.55(\mathrm{~m}, 2 \mathrm{H})$, $4.48(\mathrm{~s}, 2 \mathrm{H}), 4.44(\mathrm{~m}, 1 \mathrm{H}), 3.87(\mathrm{q}, J=10.5 \mathrm{~Hz}, 2 \mathrm{H}), 3.62(\mathrm{~m}, 2 \mathrm{H}), 3.26(\mathrm{~m}, 2 \mathrm{H}), 2.54(\mathrm{~s}$, $3 \mathrm{H}), 2.31(\mathrm{~m}, 2 \mathrm{H}), 1.99(\mathrm{~m}, 2 \mathrm{H}) .{ }^{13} \mathrm{C} \mathrm{NMR} \mathrm{CD}_{3} \mathrm{OD}(150 \mathrm{MHz}): \delta 164.3,155.9,152.7$, 138.1, 129.1, 127.6, 126.3, 125.4 (q, $J=275 \mathrm{~Hz}), 123.4,123.2,121.0,120.4,115.9,113.6$, 112.7, 106.6, 60.4, 51.1, 45.3, 35.4 (q, $J=32 \mathrm{~Hz}), 28.9$. HRMS (ESI): $\left[\mathrm{M}+\mathrm{H}^{+}\right]$calculated 505.1184; found 505.1183.

\section{6-Methoxy-4-methyl-5-((4-((6-(2,2,2-trifluoroethyl)thieno-[2,3-d]pyrimidin-4- yl)amino)piperidin-1-yl)methyl)-1 $\boldsymbol{H}$-indole-2-carbonitrile (21)-Similar procedure was used as for $\mathbf{1 4}$ but starting with $107 \mathrm{mg}(0.5 \mathrm{mmol})$ of $\mathbf{6 0 c}$. Isolated $227 \mathrm{mg}, 87 \%$ yield. ${ }^{1} \mathrm{H}$ NMR $\mathrm{CD}_{3} \mathrm{OD}(600 \mathrm{MHz}): \delta 8.70(\mathrm{~s}, 1 \mathrm{H}), 7.86(\mathrm{~s}, 1 \mathrm{H}), 7.32(\mathrm{~s}, 1 \mathrm{H}), 6.96(\mathrm{~s}, 1 \mathrm{H})$, $4.64(\mathrm{~m}, 1 \mathrm{H}), 4.54(\mathrm{~s}, 2 \mathrm{H}), 4.00(\mathrm{~s}, 3 \mathrm{H}), 3.99(\mathrm{q}, J=10.5 \mathrm{~Hz}, 2 \mathrm{H}), 3.68(\mathrm{~m}, 2 \mathrm{H}), 3.43(\mathrm{~m}$, $2 \mathrm{H}), 2.68(\mathrm{~s}, 3 \mathrm{H}), 2.32(\mathrm{~m}, 2 \mathrm{H}), 2.21(\mathrm{~m}, 2 \mathrm{H}) .{ }^{13} \mathrm{C} \mathrm{NMR} \mathrm{CD}{ }_{3} \mathrm{OD}(150 \mathrm{MHz}): \delta 159.3$, 159.1, 150.0, 139.90, 139.85, 135.8, 135.6, 133.0, 126.0 (q, $J=275 \mathrm{~Hz}), 122.9,118.8$, $115.4,114.2,112.9,106.6,92.5,56.8,55.0,53.5,50.4,35.3(\mathrm{q}, J=32 \mathrm{~Hz}), 29.6,16.5$. HRMS (ESI): $\left[\mathrm{M}+\mathrm{H}^{+}\right]$calculated 515.1835; found 515.1833.}

\section{6-Hydroxy-4-methyl-5-((4-((6-(2,2,2-trifluoroethyl)thieno-[2,3-d]pyrimidin-4- yl)amino)piperidin-1-yl)methyl)-1 $\boldsymbol{H}$-indole-2-carbonitrile (20)-26 $\mathrm{mg}(0.05 \mathrm{mmol})$ of 21 was added to $0.5 \mathrm{~mL}$ of $1 \mathrm{M} \mathrm{BBr}_{3}$ in $\mathrm{DCM}$ at $0{ }^{\circ} \mathrm{C}$, and the reaction mixture was brought to rt. After $24 \mathrm{~h}$ ice was added to the reaction mixture in the presence of sodium bicarbonate. Volatile organic was evaporated and the residue was partitioned between water and EtOAc/MeOH (10:1). Organic layer was evaporated with silica gel and the product was}


purified by column chromatography (silica gel, hexane/EtOAc/MeOH, 1:1:0.1) to afford 17 mg of 20, 68\% yield. ${ }^{1} \mathrm{H}$ NMR $\mathrm{CD}_{3} \mathrm{OD}(600 \mathrm{MHz}): \delta 8.45(\mathrm{~s}, 1 \mathrm{H}), 7.64(\mathrm{~s}, 1 \mathrm{H}), 7.28(\mathrm{~s}$, $1 \mathrm{H}), 6.84(\mathrm{~s}, 1 \mathrm{H}), 4.55(\mathrm{~m}, 1 \mathrm{H}), 4.53(\mathrm{~s}, 2 \mathrm{H}), 4.00(\mathrm{~s}, 3 \mathrm{H}), 3.90(\mathrm{q}, J=10.5 \mathrm{~Hz}, 2 \mathrm{H}), 3.67$ $(\mathrm{m}, 2 \mathrm{H}), 3.40(\mathrm{~m}, 2 \mathrm{H}), 2.65(\mathrm{~s}, 3 \mathrm{H}), 2.31(\mathrm{~m}, 2 \mathrm{H}), 2.05(\mathrm{~m}, 2 \mathrm{H}) .{ }^{13} \mathrm{C} \mathrm{NMR} \mathrm{CD}_{3} \mathrm{OD}(150$ MHz): $\delta 157.6,157.0,153.4,140.1,135.3,135.1,130.8,126.2(\mathrm{q}, J=275 \mathrm{~Hz}), 122.6$, $122.1,118.3,115.4,114.2,114.1,112.3,106.2,95.2,55.1,53.4,47.5,35.0$ (q, $J=32 \mathrm{~Hz})$, 29.8, 16.1. HRMS (ESI): $\left[\mathrm{M}+\mathrm{H}^{+}\right]$calculated 501.1679; found 501.1674.

2-(2-Cyano-4-methyl-5-((4-((6-(2,2,2-trifluoroethyl)thieno-[2,3-d]pyrimidin-4yl)amino)piperidin-1-yl)methyl)-1 $\boldsymbol{H}$-indol-1-yl)acetamide (25)-Similar procedure was used as for 7 but starting with $13 \mathrm{mg}(0.025 \mathrm{mmol})$ of $\mathbf{1 4}$. Isolated $5 \mathrm{mg}, 37 \%$ yield. ${ }^{1} \mathrm{H}$ NMR $\mathrm{CD}_{3} \mathrm{OD}(600 \mathrm{MHz}): \delta 8.37(\mathrm{~s}, 1 \mathrm{H}), 7.57(\mathrm{~d}, J=8.4 \mathrm{~Hz}, 1 \mathrm{H}), 7.52(\mathrm{~s}, 1 \mathrm{H}), 7.45(\mathrm{~d}, J=$ $8.4 \mathrm{~Hz}, 1 \mathrm{H}), 5.09(\mathrm{~s}, 2 \mathrm{H}), 4.62(\mathrm{~m}, 1 \mathrm{H}), 4.53(\mathrm{~s}, 2 \mathrm{H}), 3.88(\mathrm{q}, J=10.5 \mathrm{~Hz}, 2 \mathrm{H}), 3.61(\mathrm{~m}$, 2H), 2.72 (s, 3H), 2.34 (m, 2H), 1.96 (m, 2H). ${ }^{13} \mathrm{C} \mathrm{NMR} \mathrm{CD}_{3} \mathrm{OD}(150 \mathrm{MHz}): 171.2,167.1$, 157.7, 154.9, 139.8, 130.0, 129.4, 128.7, 126.6 (q, $J=275 \mathrm{~Hz}), 121.8,118.2,114.0,113.9$, 112.6, 110.2, 58.9, 54.8, 52.9, 48.0, 35.6 (q, $J=32 \mathrm{~Hz}$ ), 30.1, 15.8. HRMS (ESI): [M + $\left.\mathrm{H}^{+}\right]$ calculated 542.1944; found 542.1949.

\section{2-(2-Cyano-6-methoxy-4-methyl-5-((4-((6-(2,2,2-trifluoroethyl)thieno[2,3-} d]pyrimidin-4-yl)amino)piperidin-1-yl)methyl)-1 H-indol-1-yl)acetamide (26)Similar procedure was used as for 7 but starting with $26 \mathrm{mg}(0.05 \mathrm{mmol})$ of 21. Isolated 7 $\mathrm{mg}, 25 \%$ yield. ${ }^{1} \mathrm{H}$ NMR CD $\mathrm{CD}_{3} \mathrm{OD}(600 \mathrm{MHz}): \delta 8.64(\mathrm{~s}, 1 \mathrm{H}), 7.79(\mathrm{~s}, 1 \mathrm{H}), 7.43(\mathrm{~s}, 1 \mathrm{H}), 7.00$ (s, 1H), $5.05(\mathrm{~s}, 2 \mathrm{H}), 4.62(\mathrm{~m}, 1 \mathrm{H}), 4.53(\mathrm{~s}, 2 \mathrm{H}), 4.02(\mathrm{~s}, 3 \mathrm{H}), 3.98(\mathrm{q}, J=10.5 \mathrm{~Hz}, 2 \mathrm{H}), 3.66$ $(\mathrm{m}, 2 \mathrm{H}), 3.41(\mathrm{~m}, 2 \mathrm{H}), 2.67(\mathrm{~s}, 3 \mathrm{H}), 2.32(\mathrm{~m}, 2 \mathrm{H}), 2.15(\mathrm{~m}, 2 \mathrm{H}) .{ }^{13} \mathrm{C} \mathrm{NMR} \mathrm{CD}_{3} \mathrm{OD}(150$ MHz): $\delta 171.4,159.7,150.8,141.0,136.3,132.5,126.2(\mathrm{q}, J=275 \mathrm{~Hz}), 123.2,122.7$, $122.6,118.7,114.6,114.3,113.4,110.9,110.8,91.5,57.0,54.8,53.4,48.03,35.4$, (q, $J=32$ $\mathrm{Hz})$, 29.6, 16.2. HRMS (ESI): $\left[\mathrm{M}+\mathrm{H}^{+}\right]$calculated 572.2050; found 572.2055.

Methyl 2-Azido-3-(4-fluoro-3-methylphenyl)acrylate (62a)-Similar procedure was used as for 57a but starting with $0.83 \mathrm{~mL}(5 \mathrm{mmol})$ of 61a. Isolated $723 \mathrm{mg}, 60 \%$ yield. ${ }^{1} \mathrm{H}$ $\mathrm{NMR} \mathrm{CDCl}_{3}(400 \mathrm{MHz}): \delta 7.66(\mathrm{~m}, 2 \mathrm{H}), 7.01(\mathrm{~m}, 1 \mathrm{H}), 6.85(\mathrm{~s}, 1 \mathrm{H}), 3.91(\mathrm{~s}, 3 \mathrm{H}), 2.30(\mathrm{~s}$, $3 \mathrm{H})$.

Methyl 2-Azido-3-(4-methoxy-3-methylphenyl)acrylate (62b)—Similar procedure was used as for 57a but starting with $1.46 \mathrm{~mL}(10 \mathrm{mmol})$ of 61a. Isolated $1.6 \mathrm{~g}, 65 \%$ yield. ${ }^{1} \mathrm{H}$ NMR $\mathrm{CDCl}_{3}(400 \mathrm{MHz}): \delta 7.65(\mathrm{~d}, J=8.8 \mathrm{~Hz}, 1 \mathrm{H}), 7.05(\mathrm{~s}, 1 \mathrm{H}), 7.14(\mathrm{~s}, 1 \mathrm{H})$, $6.92(\mathrm{~d}, J=8.8 \mathrm{~Hz}, 1 \mathrm{H}), 3.91$ (s, 3H), 3.89 (s, 3H), 2.45 (s, 3H).

Methyl 6-Fluoro-5-methyl-1 $\boldsymbol{H}$-indole-2-carboxylate (63a)-376 $\mathrm{mg}$ (1.6 mmol) of 62a was dissolved in $1.5 \mathrm{~mL}$ of toluene. $45 \mathrm{mg}(0.075 \mathrm{mmol})$ of rhodium(II) trifluoroacetate dimer was added, and the reaction mixture was heated at $50{ }^{\circ} \mathrm{C}$ for $24 \mathrm{~h}$. Then solvent was evaporated, and the residue product was purified by column chromatography (silica gel, hexane/EtOAc, 10:1). $110 \mathrm{mg}$ (33\% yield) of compound 63a was obtained. ${ }^{1} \mathrm{H}$ NMR (600 $\mathrm{MHz}, \mathrm{CDCl}_{3}$ ): $\delta 8.81$ (br s, $\left.1 \mathrm{H}\right), 7.56(\mathrm{~s}, 1 \mathrm{H}), 7.34(\mathrm{~s}, 1 \mathrm{H}), 7.14(\mathrm{~s}, 1 \mathrm{H}), 3.92(\mathrm{~s}, 3 \mathrm{H}), 2.56$ $(\mathrm{s}, 3 \mathrm{H})$. 
Methyl 6-Methoxy-5-methyl-1H-indole-2-carboxylate (63b)—Similar procedure was used as for 63a but starting with $250 \mathrm{mg}(1.05 \mathrm{mmol})$ of 62a. Isolated $156 \mathrm{mg}, 75 \%$ yield. ${ }^{1} \mathrm{H}$ NMR CDCl 3 (400 MHz): $\delta 8.73$ (br s, $\left.1 \mathrm{H}\right), 7.39$ (s, $\left.1 \mathrm{H}\right), 7.10(\mathrm{~s}, 1 \mathrm{H}), 6.77(\mathrm{~s}, 1 \mathrm{H})$, $3.92(\mathrm{~s}, 3 \mathrm{H}), 3.88(\mathrm{~s}, 3 \mathrm{H}), 2.28(\mathrm{~s}, 3 \mathrm{H})$.

6-Fluoro-5-methyl-1 $\mathrm{H}$-indole-2-carbonitrile (64a)-Similar procedure was used as for 59a but starting with $65 \mathrm{mg}(0.31 \mathrm{mmol})$ of 63a. Isolated $31 \mathrm{mg}, 58 \%$ yield. ${ }^{1} \mathrm{H}$ NMR $\mathrm{CDCl}_{3}(400 \mathrm{MHz}): \delta 7.56(\mathrm{~s}, 1 \mathrm{H}), 7.34(\mathrm{~s}, 1 \mathrm{H}), 7.15(\mathrm{~s}, 1 \mathrm{H}), 3.90(\mathrm{~s}, 1 \mathrm{H}), 2.52(\mathrm{~s}, 3 \mathrm{H})$.

6-Methoxy-5-methyl-1 $\mathrm{H}$-indole-2-carbonitrile (64b)—Similar procedure was used as for 59a but starting with $203 \mathrm{mg}(1 \mathrm{mmol})$ of $\mathbf{6 3 b}$. Isolated $116 \mathrm{mg}, 62 \%$ yield. ${ }^{1} \mathrm{H}$ NMR $\mathrm{CDCl}_{3}(400 \mathrm{MHz}): \delta 7.37(\mathrm{~s}, 1 \mathrm{H}), 7.06(\mathrm{~s}, 1 \mathrm{H}), 6.76(\mathrm{~s}, 1 \mathrm{H}), 3.88(\mathrm{~s}, 1 \mathrm{H}), 2.35(\mathrm{~s}, 3 \mathrm{H})$.

\section{6-Fluoro-5-((4-((6-(2,2,2-trifluoroethyl)thieno[2,3- $d]$-pyrimidin-4-} yl)amino)piperidin-1-yl)methyl)-1 $\boldsymbol{H}$-indole-2-carbonitrile (16)—Similar procedure was used as for 1 but starting with $16 \mathrm{mg}(0.1 \mathrm{mmol})$ of 64a. Isolated $25 \mathrm{mg}, 50 \%$ yield. ${ }^{1} \mathrm{H}$ NMR $\mathrm{CD}_{3} \mathrm{OD}(600 \mathrm{MHz}): \delta 8.70(\mathrm{~s}, 1 \mathrm{H}), 8.04(\mathrm{~s}, 1 \mathrm{H}), 7.87(\mathrm{~s}, 1 \mathrm{H}), 7.36(\mathrm{~s}, 1 \mathrm{H}), 7.32(\mathrm{~s}$, $1 \mathrm{H}), 4.65(\mathrm{~m}, 1 \mathrm{H}), 4.55(\mathrm{~s}, 2 \mathrm{H}), 4.01(\mathrm{q}, J=10.5 \mathrm{~Hz}, 2 \mathrm{H}), 3.70(\mathrm{~m}, 2 \mathrm{H}), 3.35(\mathrm{~m}, 2 \mathrm{H}), 2.36$ (m, 2H), 2.17 (m, 2H). ${ }^{13} \mathrm{C}$ NMR CD $\mathrm{CD}_{3} \mathrm{OD}(150 \mathrm{MHz}): \delta 162.5,160.9,157.3,149.5,139.8$, 133.2, 128.9, 126.5 (q, $J=275 \mathrm{~Hz}), 124.8,123.0,118.8,114.9,114.6,112.4,109.9,99.7$, 55.6, 52.5, 35.3 (q, $J=32 \mathrm{~Hz}$ ), 29.6. HRMS (ESI): [M + $\left.\mathrm{H}^{+}\right]$calculated 489.1479; found 489.1484 .

\section{6-Methoxy-5-((4-((6-(2,2,2-trifluoroethyl)thieno[2,3- $d]$-pyrimidin-4-} yl)amino)piperidin-1-yl)methyl)-1 $\boldsymbol{H}$-indole-2-carbonitrile (18)-Similar procedure was used as for 1 but starting with $116 \mathrm{mg}(0.62 \mathrm{mmol})$ of $\mathbf{6 4 b}$. Isolated $287 \mathrm{mg}, 77 \%$ yield. ${ }^{1} \mathrm{H}$ NMR $\mathrm{CD}_{3} \mathrm{OD}(600 \mathrm{MHz}): \delta 8.71(\mathrm{~s}, 1 \mathrm{H}), 7.87(\mathrm{~s}, 1 \mathrm{H}), 7.86(\mathrm{~s}, 1 \mathrm{H}), 7.24(\mathrm{~s}, 1 \mathrm{H})$, $7.12(\mathrm{~s}, 1 \mathrm{H}), 4.66(\mathrm{~m}, 1 \mathrm{H}), 4.49(\mathrm{~s}, 2 \mathrm{H}), 4.03(\mathrm{~m}, 5 \mathrm{H}), 3.69(\mathrm{~m}, 2 \mathrm{H}), 3.34(\mathrm{~m}, 2 \mathrm{H}), 2.36(\mathrm{~m}$, 2H), $2.18(\mathrm{~m}, 2 \mathrm{H}) .{ }^{13} \mathrm{C}$ NMR CD${ }_{3} \mathrm{OD}(150 \mathrm{MHz}): \delta 158.7,149.7,140.9,133.1,128.2$, $127.8,127.3,126.4$ (q, $J=275 \mathrm{~Hz}), 123.4,122.8,121.7,118.7,115.1,114.8,114.6,107.5$, 94.6, 57.7, 56.6, 52.7, $35.2(\mathrm{q}, J=33 \mathrm{~Hz}), 29.5$. HRMS (ESI): $\left[\mathrm{M}+\mathrm{H}^{+}\right]$calculated 501.1679; found 501.1674 .

\section{6-Hydroxy-5-((4-((6-(2,2,2-trifluoroethyl)thieno[2,3- d]-pyrimidin-4-} yl)amino)piperidin-1-yl)methyl)-1 $\boldsymbol{H}$-indole-2-carbonitrile (17)—Similar procedure was used as for 20 but starting with $50 \mathrm{mg}(0.1 \mathrm{mmol})$ of $\mathbf{1 8}$. Isolated $27 \mathrm{mg}, 56 \%$ yield. ${ }^{1} \mathrm{H}$ NMR CD ${ }_{3} \mathrm{OD}(600 \mathrm{MHz}): \delta 8.70(\mathrm{~s}, 1 \mathrm{H}), 7.81(\mathrm{~s}, 1 \mathrm{H}), 7.77(\mathrm{~s}, 1 \mathrm{H}), 7.21(\mathrm{~s}, 1 \mathrm{H}), 6.98(\mathrm{~s}$, $1 \mathrm{H}), 4.64(\mathrm{~m}, 1 \mathrm{H}), 4.48(\mathrm{~s}, 2 \mathrm{H}), 4.01(\mathrm{q}, J=10.3 \mathrm{~Hz}, 2 \mathrm{H}), 3.66(\mathrm{~m}, 2 \mathrm{H}), 3.35(\mathrm{~m}, 2 \mathrm{H}), 2.37$ (m, 2H), $2.12(\mathrm{~m}, 2 \mathrm{H}) .{ }^{13} \mathrm{C}$ NMR CD ${ }_{3} \mathrm{OD}$ (150 MHz): $\delta 157.6,156.6,153.9,141.1,130.5$, 127.8, 127.5, 126.4 (q, $J=275 \mathrm{~Hz}), 125.7,122.0,121.6,118.3,115.2,114.9,114.0,107.1$, 97.5, 57.8, 52.9, 47.9, $35.5(\mathrm{q}, J=33 \mathrm{~Hz}), 30.0 . \mathrm{HRMS}(\mathrm{ESI}):\left[\mathrm{M}+\mathrm{H}^{+}\right]$calculated 487.1522; found 487.1519 .

\section{6-Ethoxy-5-((4-((6-(2,2,2-trifluoroethyl)thieno[2,3- $d]$-pyrimidin-4-} yl)amino)piperidin-1-yl)methyl)-1 $\boldsymbol{H}$-indole-2-carbonitrile (19) - $14 \mathrm{mg}(0.029$ mmol) of 17 was dissolved in $0.1 \mathrm{~mL}$ of $\mathrm{CH}_{3} \mathrm{CN} .12 \mathrm{mg}(0.087 \mathrm{mmol})$ of $\mathrm{K}_{2} \mathrm{CO}_{3}$ and $4.7 \mu \mathrm{L}$ 
$(0.058 \mathrm{mmol})$ of EtI were added, and the mixture was stirred for $24 \mathrm{~h}$. Then reaction mixture was directly subjected to purification by preparative TLC (silica gel, hexane/EtOAc/MeOH, 1:1:0.2) and the product was extracted from silica gel with methanol to afford $9 \mathrm{mg}$ of $\mathbf{1 9}$, $61 \%$ yield. ${ }^{1} \mathrm{H}$ NMR $\mathrm{CD}_{3} \mathrm{OD}(600 \mathrm{MHz}): \delta 8.65(\mathrm{~s}, 1 \mathrm{H}), 7.84(\mathrm{~s}, 1 \mathrm{H}), 7.80(\mathrm{~s}, 1 \mathrm{H}), 7.28(\mathrm{~s}$, 1H), $7.25(\mathrm{~s}, 1 \mathrm{H}), 4.60(\mathrm{~m}, 1 \mathrm{H}), 4.47(\mathrm{~s}, 2 \mathrm{H}), 4.29(\mathrm{~m}, 2 \mathrm{H}), 3.99$ (q, $J=10.3 \mathrm{~Hz}, 2 \mathrm{H}), 3.67$ $(\mathrm{m}, 2 \mathrm{H}), 3.58(\mathrm{~m}, 2 \mathrm{H}), 2.35(\mathrm{~m}, 2 \mathrm{H}), 2.10(\mathrm{~m}, 2 \mathrm{H}), 1.55(\mathrm{t}, J=7 \mathrm{~Hz}, 3 \mathrm{H}) .{ }^{13} \mathrm{C}$ NMR $\mathrm{CD}_{3} \mathrm{OD}$ (150 MHz): $\delta 157.9,157.4,150.4,132.6,128.3,126.2$ (q, $J=275 \mathrm{~Hz}), 122.6,121.3,118.6$, 114.8, 114.6, 111.5, 94.8, 65.7, 57.4, 52.8, 43.8, 35.5 (q, $J=33 \mathrm{~Hz}), 29.6,15.0$. HRMS (ESI): $\left[\mathrm{M}+\mathrm{H}^{+}\right]$calculated 515.1835; found 515.1834.

(1-Trityl-1 H-pyrazol-4-yl)methanol (66) - $5 \mathrm{~g}$ of ethyl $1 H$-pyrazole-4-carboxylate (35.7 mmol) was dissolved in $70 \mathrm{~mL}$ of DMF, and $4.8 \mathrm{~g}(42.8 \mathrm{mmol})$ of potassium tert-butoxide was added. After stirring for $30 \mathrm{~min} 13.9 \mathrm{~g}(50 \mathrm{mmol})$ of trityl chloride was added in small portions. TLC indicated no starting material after $1 \mathrm{~h}$ of stirring, and the reaction mixture was diluted with $300 \mathrm{~mL}$ of water and extracted with $3 \times 50 \mathrm{~mL}$ of DCM. Organic extracts were evaporated and then dissolved in $300 \mathrm{~mL}$ of THF. $2.03 \mathrm{~g}(53.6 \mathrm{mmol})$ of lithium aluminohydride was added in small portions. After $1 \mathrm{~h}$ the reaction mixture was carefully quenched with $10 \mathrm{~mL}$ of ethyl acetate followed by addition of $5 \mathrm{~mL}$ of water. $15 \mathrm{~g}$ of silica gel was added, and the solvent was evaporated. The product was purified by column chromatography (silica gel, hexane/EtOAc, 1:1), resulting in $11.75 \mathrm{~g}$ of $\mathbf{6 6}, 97 \%$ yield. ${ }^{1} \mathrm{H}$ $\mathrm{NMR} \mathrm{CDCl}_{3}$ (600 MHz): $\delta 7.67(\mathrm{~s}, 1 \mathrm{H}), 7.38(\mathrm{~s}, 1 \mathrm{H}), 7.31(\mathrm{~m}, 9 \mathrm{H}), 7.14(\mathrm{~m}, 6 \mathrm{H}), 4.55(\mathrm{~s}$, $2 \mathrm{H}), 1.47$ (s, 1H). ${ }^{13} \mathrm{C} \mathrm{NMR} \mathrm{CDCl}_{3}(150 \mathrm{MHz}): \delta 143.2,139.1,131.4,130.1,127.8,120.0$, 78.7, 56.3.

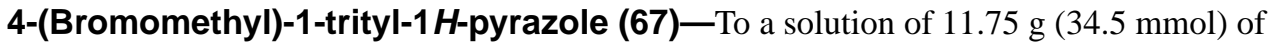

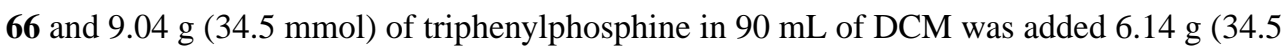
mmol) of $N$-bromosuccinimide at $0{ }^{\circ} \mathrm{C}$. Then mixture was stirred for $30 \mathrm{~min}$ and transferred to a separatory funnel, washed with saturated sodium bicarbonate solution and brine, dried over sodium sulfate. After evaporation, the product was purified by column chromatography (neutralized silica gel, hexane/EtOAc, 10:1). Silica gel neutralization (for $50 \mathrm{~g}$ of silica gel): washed with $500 \mathrm{~mL}$ of $0.05 \%$ of ammonia (25\% in water) in EtOAc, $500 \mathrm{~mL}$ of pure EtOAc, and $500 \mathrm{~mL}$ of hexane. $11.09 \mathrm{~g}$ of $\mathbf{6 7}$ was obtained and it was used in subsequent step immediately (decomposes upon standing), $79 \%$ yield.

5-Formyl-6-methoxy-1 H-indole-2-carbonitrile (68b)-Similar procedure was used as for 60b but starting with $744 \mathrm{mg}(4 \mathrm{mmol})$ of $\mathbf{6 4 b}$. Isolated $300 \mathrm{mg}, 38 \%$ yield. ${ }^{1} \mathrm{H}$ NMR $\mathrm{CD}_{3} \mathrm{CN}(600 \mathrm{MHz}): \delta 10.46$ (s, 1H), 9.78 (br s, 1H), 7.33 (s, 1H), 7.15 (s, 1H), 6.99 (s, 1H), $3.92(\mathrm{~s}, 3 \mathrm{H})$.

\section{5-Formyl-6-methoxy-4-methyl-1-(2-(trityloxy)ethyl)-1 $\mathrm{H}$-in-dole-2-carbonitrile} (69)-A mixture of $44 \mathrm{mg}(0.21 \mathrm{mmol})$ of $60 \mathrm{c}, 113 \mathrm{mg}(0.31 \mathrm{mmol})$ of 1-tritoxy-2bromoethane (see 44 for preparation), and $197 \mathrm{mg}(0.6 \mathrm{mmol})$ of $\mathrm{Cs}_{2} \mathrm{CO}_{3}$ in $0.4 \mathrm{~mL}$ of DMF was heated at $40{ }^{\circ} \mathrm{C}$ for $3 \mathrm{~h}$. The reaction mixture was diluted with water and extracted with DCM. Organic phase was evaporated with silica gel and loaded on silica gel column. The product was purified with hexane/EtOAc 1:1 to afford $50 \mathrm{mg}$ of $\mathbf{6 9}, 50 \%$ yield. ${ }^{1} \mathrm{H}$ NMR 
$\mathrm{CD}_{3} \mathrm{CN}(600 \mathrm{MHz}): 10.65(\mathrm{~s}, 1 \mathrm{H}), 7.32(\mathrm{~s}, 1 \mathrm{H}), 7.17(\mathrm{~m}, 15 \mathrm{H}), 6.65(\mathrm{~s}, 1 \mathrm{H}), 4.41(\mathrm{t}, 5.3 \mathrm{~Hz}$, $2 \mathrm{H}), 3.90(\mathrm{~s}, 3 \mathrm{H}), 3.50(\mathrm{t}, 5.3 \mathrm{~Hz}, 2 \mathrm{H}), 2.81(\mathrm{~s}, 3 \mathrm{H})$.

5-Formyl-4-methyl-1-((1-trityl-1 H-pyrazol-4-yl)methyl)-1 H-indole-2-carbonitrile (70)-11.09 g (27.5 mmol) of 67, $2.53 \mathrm{~g}$ (13.8 mmol) of 5-formyl-4-methyl-1 $H$-indole-2carbonitrile, and $13.6 \mathrm{~g}$ ( $41.4 \mathrm{mmol})$ of cesium carbonate were stirred in $28 \mathrm{~mL}$ of DMF for $30 \mathrm{~min}$. Then the reaction mixture was diluted with $300 \mathrm{~mL}$ of water and $200 \mathrm{~mL}$ of diethyl ether. After stirring for $4 \mathrm{~h}$ the precipitate was filtered off, washed with additional $100 \mathrm{~mL}$ of water and $100 \mathrm{~mL}$ of diethyl ether, and dried to afford $6.4 \mathrm{~g}$ of $\mathbf{7 0}, 92 \%$ yield. ${ }^{1} \mathrm{H}$ NMR DMSO- $d_{6}(600 \mathrm{MHz}): \delta 10.02(\mathrm{~s}, 1 \mathrm{H}), 7.85(\mathrm{~s}, 1 \mathrm{H}), 7.82(\mathrm{~d}, J=8.4 \mathrm{~Hz}, 1 \mathrm{H}), 7.77(\mathrm{~d}, J=$ $8.4 \mathrm{~Hz}, 1 \mathrm{H}), 7.58(\mathrm{~s}, 1 \mathrm{H}), 7.50(\mathrm{~s}, 1 \mathrm{H}), 7.36(\mathrm{~m}, 9 \mathrm{H}), 7.00(\mathrm{~m}, 6 \mathrm{H}), 5.47(\mathrm{~s}, 2 \mathrm{H}), 2.83(\mathrm{~s}$, $3 \mathrm{H})) .{ }^{13} \mathrm{C}$ NMR DMSO- $d_{6}(150 \mathrm{MHz}): \delta 191.1,162.3,142.7,142.6,138.5,132.1,129.7$, 129.6, 127.9, 127.8, 127.1, 126.6, 115.6, 114.9, 109.8, 109.4, 78.5, 78.1, 14.1 .

5-Formyl-6-methoxy-1-((1-trityl-1 H-pyrazol-4-yl)methyl)-1 H-indole-2carbonitrile (71)—Similar procedure was used as for $\mathbf{7 0}$ but starting with $300 \mathrm{mg}$ (1.5 $\mathrm{mmol}$ ) of $\mathbf{6 8 b}$. Isolated $642 \mathrm{mg}$ of 71, 82\% yield. ${ }^{1} \mathrm{H}$ NMR DMSO- $d_{6}(600 \mathrm{MHz}): \delta 9.89(\mathrm{~s}$, $1 \mathrm{H}), 7.56(\mathrm{~s}, 1 \mathrm{H}), 7.51(\mathrm{~s}, 1 \mathrm{H}), 7.44(\mathrm{~s}, 1 \mathrm{H}), 7.34(\mathrm{~m}, 9 \mathrm{H}), 7.23(\mathrm{~s}, 1 \mathrm{H}), 7.15(\mathrm{~s}, 1 \mathrm{H}), 7.02$ (m, 6H), $5.43(\mathrm{~s}, 2 \mathrm{H}), 2.72(\mathrm{~s}, 3 \mathrm{H})$.

\section{5-Formyl-6-methoxy-4-methyl-1-((1-trityl-1 H-pyrazol-4-yl)-methyl)-1 $H$-indole-2-} carbonitrile (72)—Similar procedure was used as for $\mathbf{7 0}$ but starting with $535 \mathrm{mg}(2.5$ mmol) of 60c. Isolated $1.30 \mathrm{~g}, 94 \%$ yield. ${ }^{1} \mathrm{H} \mathrm{NMR} \mathrm{CDCl}{ }_{3}(600 \mathrm{MHz}): 10.63(\mathrm{~s}, 1 \mathrm{H}), 7.57$ (s, 1H), $7.42(\mathrm{~s}, 1 \mathrm{H}), 7.30(\mathrm{~m}, 9 \mathrm{H}), 7.10(\mathrm{~m}, 6 \mathrm{H}), 6.57(\mathrm{~s}, 1 \mathrm{H}), 5.24(\mathrm{~s}, 2 \mathrm{H}), 3.84(\mathrm{~s}, 3 \mathrm{H})$, $2.76(\mathrm{~s}, 3 \mathrm{H})$.

(4-((2-Cyano-5-formyl-6-methoxy-4-methyl-1 $H$-indol-1-yl)-methyl)-1 $H$-1,2,3triazol-1-yl)methyl Pivalate (73)—Similar procedure was used as for $\mathbf{6 9}$ but starting with $180 \mathrm{mg}(0.84 \mathrm{mmol})$ of $\mathbf{6 0 c}$ and $0.14 \mathrm{~mL}(1.26 \mathrm{mmol})$ of propargyl bromide $(80 \%$ in toluene). Crude intermediate, $0.13 \mathrm{~mL}(0.84 \mathrm{mmol})$ of $t-\mathrm{BuCO}_{2} \mathrm{CH}_{2} \mathrm{~N}_{3}, 50 \mathrm{mg}(0.25 \mathrm{mmol})$ of sodium ascorbate, and $6.7 \mathrm{mg}(0.042 \mathrm{mmol})$ of $\mathrm{CuSO}_{4}$ were dissolved in $2.5 \mathrm{~mL}$ of $t$ $\mathrm{BuOH} / \mathrm{H}_{2} \mathrm{O}(1: 1)$, and the reaction mixture was heated at $60{ }^{\circ} \mathrm{C}$ for $4 \mathrm{~h}$. The reaction mixture was then diluted with water and extracted with DCM. Organic phase was evaporated with silica gel and loaded on silica gel column. The product was purified by column chromatography (silica gel, hexane/EtOAc, 1:1) to afford $307 \mathrm{mg}$ of $\mathbf{7 3}, 90 \%$ yield. ${ }^{1} \mathrm{H}$ $\mathrm{NMR} \mathrm{CDCl}_{3}(600 \mathrm{MHz}): \delta 10.56(\mathrm{~s}, 1 \mathrm{H}), 7.78(\mathrm{~s}, 1 \mathrm{H}), 7.39(\mathrm{~s}, 1 \mathrm{H}), 6.58(\mathrm{~s}, 1 \mathrm{H}), 5.27(\mathrm{~s}$, 2H), 4.98 (s, 2H), 3.83 (s, 3H), 2.74 (s, 3H), 1.89 (s, 9H).

1-(2-Hydroxyethyl)-6-methoxy-4-methyl-5-((4-((6-(2,2,2-trifluoroethyl)thieno[2,3d]pyrimidin-4-yl)amino)piperidin-1-yl)methyl)-1 H-indole-2-carbonitrile (24)-

Similar procedure was used as for $\mathbf{1 4}$ for reductive amination and for $\mathbf{2}$ for deprotection but starting with $100 \mathrm{mg}(0.2 \mathrm{mmol})$ of 69. Isolated $80 \mathrm{mg}, 72 \%$ yield. ${ }^{1} \mathrm{H}$ NMR $\mathrm{CD}_{3} \mathrm{OD}(600$ MHz): $\delta 8.53(\mathrm{~s}, 1 \mathrm{H}), 7.70(\mathrm{~s}, 1 \mathrm{H}), 7.39(\mathrm{~s}, 1 \mathrm{H}), 7.08(\mathrm{~s}, 1 \mathrm{H}), 4.56(\mathrm{~m}, 1 \mathrm{H}), 4.43(\mathrm{~s}, 2 \mathrm{H})$, $4.43(\mathrm{t}, J=5.1 \mathrm{~Hz}, 2 \mathrm{H}), 4.03(\mathrm{~s}, 3 \mathrm{H}), 3.92(\mathrm{~m}, 4 \mathrm{H}), 3.65(\mathrm{~m}, 2 \mathrm{H}), 3.40(\mathrm{~m}, 2 \mathrm{H}), 2.67(\mathrm{~s}, 1 \mathrm{H})$, $2.33(\mathrm{~m}, 2 \mathrm{H}), 2.09$ (m, 2H). ${ }^{13} \mathrm{C}$ NMR $\mathrm{CD}_{3} \mathrm{OD}(150 \mathrm{MHz}): \delta 159.4,157.7,152.5,140.5$, 
136.1, 135.9, 131.6, 129.4, 126.6 (q, $J=275 \mathrm{~Hz}), 122.7,122.6,122.4,118.6,114.8,114.1$, 113.2, 110.4, 91.9, 61.9, 56.9, 54.9, 53.5, 50,4, 47.9, 35.5 (q, $J=33 \mathrm{~Hz}), 29.8,16.2$. HRMS (ESI): $\left[\mathrm{M}+\mathrm{H}^{+}\right]$calculated 559.2098; found 559.2092.

6-Hydroxy-1-(2-hydroxyethyl)-4-methyl-5-((4-((6-(2,2,2-trifluoroethyl)thieno[2,3d]pyrimidin-4-yl)amino)piperidin-1-yl)methyl)-1 $\mathrm{H}$-indole-2-carbonitrile (23)Similar procedure was used as for $\mathbf{2 0}$ but starting with $50 \mathrm{mg}(0.089 \mathrm{mmol})$ of 24. Isolated $22 \mathrm{mg}, 46 \%$ yield. ${ }^{1} \mathrm{H}$ NMR CD $\mathrm{CD}_{3} \mathrm{OD}(600 \mathrm{MHz}): \delta 8.38(\mathrm{~s}, 1 \mathrm{H}), 7.58(\mathrm{~s}, 1 \mathrm{H}), 7.34$ (s, 1), $6.88(\mathrm{~s}, 1 \mathrm{H}), 4.61(\mathrm{~m}, 1 \mathrm{H}), 4.53(\mathrm{~s}, 2 \mathrm{H}), 4.32(\mathrm{t}, J=5.1 \mathrm{~Hz}, 2 \mathrm{H}), 3.87(\mathrm{~m}, 4 \mathrm{H}), 3.66(\mathrm{~m}, 2 \mathrm{H})$, $3.39(\mathrm{~m}, 2 \mathrm{H}), 2.64(\mathrm{~s}, 3 \mathrm{H}), 2.32(\mathrm{~m}, 2 \mathrm{H}), 2.04(\mathrm{~m}, 2 \mathrm{H}) .{ }^{13} \mathrm{C} \mathrm{NMR} \mathrm{CD}_{3} \mathrm{OD}(150 \mathrm{MHz}): \delta$ 166.6, 158.2, 157.7, 154.9, 141.1, 136.4, 136.3, 130.8, 128.1, 126.5 (q, $J=275 \mathrm{~Hz}), 122.8$, $122.5,118.8,115.4,114.8,114.6,113.1,110.5,94.8,63.5,62.1,55.5,54.0,47.7,36.3$ (q, $J$ $=33 \mathrm{~Hz}$ ), 30.4, 16.5. HRMS (ESI): [M + H+ $]$ calculated 545.1941; found 545.1941.

1-((1 H-Pyrazol-4-yl)methyl)-6-methoxy-4-methyl-5-((4-((6-(2,2,2trifluoroethyl)thieno[2,3-d]pyrimidin-4-yl)amino)-piperidin-1-yl)methyl)-1 Hindole-2-carbonitrile (28)-Similar procedure was used as for $\mathbf{1 4}$ for reductive amination and 2 for deprotection but starting with $642 \mathrm{mg}(1.23 \mathrm{mmol})$ of 71. Isolated $430 \mathrm{mg}, 60 \%$ yield. ${ }^{1} \mathrm{H}$ NMR $\mathrm{CD}_{3} \mathrm{OD}(600 \mathrm{MHz}): \delta 8.46(\mathrm{~s}, 1 \mathrm{H}), 7.83(\mathrm{~s}, 1 \mathrm{H}), 7.66(\mathrm{~s}, 1 \mathrm{H}), 7.64(\mathrm{~s}, 2 \mathrm{H})$, $7.30(\mathrm{~s}, \mathrm{H}), 7.28(\mathrm{~s}, 1 \mathrm{H}), 5.47$ (s, 2H), $4.49(\mathrm{~m}, 1 \mathrm{H}), 4.44$ (s, 2H), 4.06 (s, 3H), 3.90 (q, $J=$ $10.3 \mathrm{~Hz}, 2 \mathrm{H}), 3.62(\mathrm{~m}, 2 \mathrm{H}), 3.28(\mathrm{~m}, 2 \mathrm{H}), 2.32(\mathrm{~m}, 2 \mathrm{H}), 2.04(\mathrm{~m}, 2 \mathrm{H}) .{ }^{13} \mathrm{C} \mathrm{NMR} \mathrm{CD}_{3} \mathrm{OD}$ (150 MHz): $\delta 164.5,159.0,157.5,152.9,140.6,134.2,131.0,128.7,126.4$ (q, $J=275 \mathrm{~Hz}$ ), $122.4,122.2,121.4,121.2,118.3,117.7,115.2,115.0,114.6,110.2,93.6,61.0,57.4,56.8$, $56.2,52.9,52.7,47.5,40.3,35.5(\mathrm{q}, J=33 \mathrm{~Hz}), 29.8$. HRMS (ESI): $\left[\mathrm{M}+\mathrm{H}^{+}\right]$calculated 581.2053; found 581.2059.

1-((1 H-Pyrazol-4-yl)methyl)-6-hydroxy-5-((4-((6-(2,2,2-trifluoroethyl)thieno[2,3d]pyrimidin-4-yl)amino)piperidin-1-yl)methyl)-1 $\mathrm{H}$-indole-2-carbonitrile (27)-

Similar procedure was used as for $\mathbf{2 0}$ but starting with $580 \mathrm{mg}(1 \mathrm{mmol})$ of $\mathbf{2 8}$. Isolated 253 mg, $45 \%$ yield. ${ }^{1} \mathrm{H}$ NMR CD ${ }_{3} \mathrm{OD}(600 \mathrm{MHz}): \delta 8.35(\mathrm{~s}, 1 \mathrm{H}), 7.77(\mathrm{~s}, 1 \mathrm{H}), 7.58(\mathrm{~s}, 2 \mathrm{H}), 7.35$ (s, 1H), $7.24(\mathrm{~s}, 1 \mathrm{H}), 7.07(\mathrm{~s}, 1 \mathrm{H}), 5.35(\mathrm{~s}, 2 \mathrm{H}), 4.44(\mathrm{~m}, 3 \mathrm{H}), 3.86(\mathrm{~m}, 2 \mathrm{H}), 3.64(\mathrm{~m}, 2 \mathrm{H})$, 3.27 (m, 2H), $2.32(\mathrm{~m}, 2 \mathrm{H}), 1.98(\mathrm{~m}, 2 \mathrm{H}) .{ }^{13} \mathrm{C} \mathrm{NMR} \mathrm{CD}{ }_{3} \mathrm{OD}(150 \mathrm{MHz}): \delta 176.4,166.6$, 157.7, 156.9, 154.6, 140.8, 130.0, 128.5, 126.5 (q, $J 275 \mathrm{~Hz}), 121.8,121.4,118.2,117.6$, 151.2, 114.6, 114.4, 110.0, 96.4, 57.5, 52.9, 47.0, 40.4, 35.6 (q, $J=33 \mathrm{~Hz}), 30.0$. HRMS (ESI): $\left[\mathrm{M}+\mathrm{H}^{+}\right]$calculated 567.1897; found 567.1892.

1-((1 H-Pyrazol-4-yl)methyl)-4-methyl-5-((4-((6-(2,2,2-trifluoroethyl)thieno[2,3d]pyrimidin-4-yl)amino)piperidin-1-yl)methyl)-1 H-indole-2-carbonitrile (29)Similar procedure was used as for $\mathbf{1 4}$ for reductive amination and $\mathbf{2}$ for deprotection but starting with $5.5 \mathrm{~g}(10.8 \mathrm{mmol})$ of 70. Isolated $3.7 \mathrm{~g}, 58 \%$ yield. ${ }^{1} \mathrm{H}$ NMR $\mathrm{CD}_{3} \mathrm{OD}(600$ $\mathrm{MHz}):{ }^{1} \mathrm{H}$ NMR CD $3 \mathrm{OD}(600 \mathrm{MHz}): \delta 8.36(\mathrm{~s}, 1 \mathrm{H}), 7.63(\mathrm{~m}, 5 \mathrm{H}), 7.43(\mathrm{~s}, 1 \mathrm{H}), 5.45(\mathrm{~s}$, $2 \mathrm{H}), 4.53(\mathrm{~s}, 2 \mathrm{H}), 4.46(\mathrm{~m}, 1 \mathrm{H}), 3.86(\mathrm{q}, J=10.5 \mathrm{~Hz}, 2 \mathrm{H}), 3.63(\mathrm{~m}, 2 \mathrm{H}), 3.34(\mathrm{~m}, 2 \mathrm{H}), 2.67$ (s, 3H), $2.32(\mathrm{~m}, 2 \mathrm{H}), 2.03(\mathrm{~m}, 2 \mathrm{H}) .{ }^{13} \mathrm{C}$ NMR CD $3 \mathrm{OD}(150 \mathrm{MHz}): \delta 165.72,157.61$, 154.23, 138.70, 135.18, 134.22, 130.91, 130.30, 128.73, 126.60 (q, $J=289.5 \mathrm{~Hz}), 122.71$, $121.99,121.12,118.22,114.39,114.04,111.04,110.61,58.83,52.87,47.25,40.50,35.61$

$J$ Med Chem. Author manuscript; available in PMC 2016 November 02. 
(q, $J=32 \mathrm{~Hz}), 29.90,27.34,15.89 . \mathrm{HRMS}(\mathrm{ESI}):\left[\mathrm{M}+\mathrm{H}^{+}\right]$calculated 565.2104; found 565.2107 .

1-((1H-Pyrazol-4-yl)methyl)-6-methoxy-4-methyl-5-((4-((6-(2,2,2trifluoroethyl)thieno[2,3-d]pyrimidin-4-yl)amino)-piperidin-1-yl)methyl)-1 Hindole-2-carbonitrile (31) - Similar procedure was used as for $\mathbf{1 4}$ for reductive amination and for 2 for deprotection but starting with $1053 \mathrm{mg}(3 \mathrm{mmol})$ of $\mathbf{7 2}$. Isolated $890 \mathrm{mg}, 50 \%$ yield. ${ }^{1} \mathrm{H}$ NMR $\mathrm{CD}_{3} \mathrm{OD}(600 \mathrm{MHz}): \delta 8.39(\mathrm{~s}, 1 \mathrm{H}), 7.62(\mathrm{~s}, 2 \mathrm{H}), 7.60(\mathrm{~s}, 1 \mathrm{H}), 7.39(\mathrm{~s}, 1 \mathrm{H})$, $7.17(\mathrm{~s}, 1 \mathrm{H}), 5.46(\mathrm{~s}, 1 \mathrm{H}), 4.52(\mathrm{~s}, 2 \mathrm{H}), 4.48(\mathrm{~m}, 1 \mathrm{H}), 4.05(\mathrm{~s}, 3 \mathrm{H}), 3.87$ (q, 2H, $J=10.3 \mathrm{~Hz})$, $3.64(\mathrm{~m}, 2 \mathrm{H}), 3.39(\mathrm{~m}, 2 \mathrm{H}), 2.65(\mathrm{~s}, 3 \mathrm{H}), 2.32(\mathrm{~m}, 2 \mathrm{H}), 2.05(\mathrm{~m}, 2 \mathrm{H}) .{ }^{13} \mathrm{C} \mathrm{NMR} \mathrm{CD}_{3} \mathrm{OD}$ (150 MHz): 165.7, 159.8, 157.9, 154.4, 139.9, 136.5, 136.3, 134.4, 130.7, 126.8 (q, $J=275$ Hz), 122.3, 118.5, 118.0, 115.0, 114.8, 113.6, 109.6, 91.8, 57.2, 54.9, 53.8, 47.5, 40.6, 35.8 (q, $J=33 \mathrm{~Hz}$ ), 30.07, 16.4. HRMS (ESI): [M + $\left.\mathrm{H}^{+}\right]$calculated 595.2210; found 595.2217.

1-((1 H-Pyrazol-4-yl)methyl)-6-hydroxy-4-methyl-5-((4-)(6-(2,2,2trifluoroethyl)thieno[2,3-d]pyrimidin-4-yl)amino)-piperidin-1-yl)methyl)-1 Hindole-2-carbonitrile (30)_Similar procedure was used as for $\mathbf{2 0}$ but starting with $36 \mathrm{mg}$ $(0.06 \mathrm{mmol})$ of 31. Isolated $17 \mathrm{mg}, 49 \%$ yield. ${ }^{1} \mathrm{H}$ NMR CD $3 \mathrm{OD}(600 \mathrm{MHz}): 8.36(\mathrm{~s}, 1 \mathrm{H})$, $7.56(\mathrm{~s}, 2 \mathrm{H}), 7.49(\mathrm{~s}, 1 \mathrm{H}), 7.36(\mathrm{~s}, 1 \mathrm{H}), 6.94(\mathrm{~s}, 1 \mathrm{H}), 5.34(\mathrm{~s}, 2 \mathrm{H}), 4.52(\mathrm{~s}, 2 \mathrm{H}), 4.45(\mathrm{~m}, 1 \mathrm{H})$, $3.86(\mathrm{~m}, 2 \mathrm{H}), 3.65(\mathrm{~m}, 2 \mathrm{H}), 3.40(\mathrm{~m}, 2 \mathrm{H}), 2.32(\mathrm{~m}, 2 \mathrm{H}), 2.01(\mathrm{~m}, 2 \mathrm{H}) .{ }^{13} \mathrm{C} \mathrm{NMR} \mathrm{CD} \mathrm{CD}_{3} \mathrm{OD}$ (150 MHz): 166.8, 157.8, 154.8, 154.2, 140.0, 135.9, 130.2, 126.4 (q, $J=275 \mathrm{~Hz}), 125.1$, $122.5,122.0,118.8,117.8,115.6,114.6,112.9,112.3,109.2,94.3,55.1,53.7,47.2,42.2$, 40.5, 35.7 (q, $J=33 \mathrm{~Hz}$ ), 30.0, 16.1. HRMS (ESI): [M + $\left.\mathrm{H}^{+}\right]$calculated 581.2053; found 581.2046.

1-((1H-1,2,3-Triazol-4-yl)methyl)-6-methoxy-4-methyl-5-((4-((6-(2,2,2trifluoroethyl)thieno[2,3-d]pyrimidin-4-yl)amino)-piperidin-1-yl)methyl)-1 Hindole-2-carbonitrile (34)—Reductive amination was completed using a similar procedure as for synthesis of $\mathbf{1 3}$, starting with $307 \mathrm{mg}(0.75 \mathrm{mmol})$ of 73. Protected intermediate was dissolved in $2 \mathrm{~mL}$ of $\mathrm{MeOH}$, and $530 \mathrm{mg}(9.3 \mathrm{mmol})$ of $\mathrm{KOH}$ was added. After 30 min the reaction mixture was diluted with water and the product was extracted with EtOAc. Organic phase was evaporated with silica gel and the product was purified by column chromatography (silica gel, DCM/MeOH, 10:1) to afford $390 \mathrm{mg}$ of $\mathbf{3 4}, 87 \%$ yield. ${ }^{1} \mathrm{H}$ NMR $\mathrm{CD}_{3} \mathrm{OD}(600 \mathrm{MHz}): \delta 8.35(\mathrm{~s}, 1 \mathrm{H}), 7.57(\mathrm{~s}, 1 \mathrm{H}), 7.40(\mathrm{~s}, 1 \mathrm{H}), 7.18(\mathrm{~s}, 1 \mathrm{H})$, $5.63(\mathrm{~s}, 2 \mathrm{H}), 4.51(\mathrm{~s}, 2 \mathrm{H}), 4.45(\mathrm{~m}, 1 \mathrm{H}), 4.04(\mathrm{~s}, 3 \mathrm{H}), 3.86(\mathrm{q}, J=10.3 \mathrm{~Hz}, 2 \mathrm{H}), 3.63(\mathrm{~m}$, $2 \mathrm{H}), 3.36(\mathrm{~m}, 2 \mathrm{H}), 2.65(\mathrm{~s}, 3 \mathrm{H}), 2.31(\mathrm{~m}, 2 \mathrm{H}), 2.04(\mathrm{~m}, 2 \mathrm{H}) .{ }^{13} \mathrm{C} \mathrm{NMR} \mathrm{CD}_{3} \mathrm{OD}(150 \mathrm{MHz})$ : $\delta 166.6,159.7,157.8,154.7,140.1,136.3,130.2,126.5(\mathrm{q}, J=275 \mathrm{~Hz}), 122.7,122.0,118.3$, 114.9, 114.6, 113.6, 109.7, 91.9, 57.0, 54.8, 53.7, 47.2, 41.2, 35.7 (q, $J=33 \mathrm{~Hz}), 30.0,16.2$. HRMS (ESI): $\left[\mathrm{M}+\mathrm{H}^{+}\right]$calculated 596.2162; found 596.2157.

1-((1 H-1,2,3-Triazol-4-yl)methyl)-6-hydroxy-4-methyl-5-((4-((6-(2,2,2trifluoroethyl)thieno[2,3-d]pyrimidin-4-yl)amino)-piperidin-1-yl)methyl)-1 Hindole-2-carbonitrile (33)-Similar procedure was used as for 20 but starting with 100 $\mathrm{mg}(0.17 \mathrm{mmol})$ of $\mathbf{3 4}$. Isolated $17 \mathrm{mg}, 17 \%$ yield. ${ }^{1} \mathrm{H}$ NMR $\mathrm{CD}_{3} \mathrm{OD}(600 \mathrm{MHz}): \delta 8.35$ (s, 1H), $7.72(\mathrm{br} \mathrm{s}, 1 \mathrm{H}), 7.56(\mathrm{~s}, 1 \mathrm{H}), 7.38(\mathrm{~s}, 1 \mathrm{H}), 6.95(\mathrm{~s}, 1 \mathrm{H}), 5.52(\mathrm{~s}, 2 \mathrm{H}), 4.51(\mathrm{~s}, 2 \mathrm{H}), 4.45$ 
(m, 1H), $3.86(\mathrm{q}, J=10.5 \mathrm{~Hz}, 2 \mathrm{H}), 3.64(\mathrm{~m}, 2 \mathrm{H}), 3.37(\mathrm{~m}, 2 \mathrm{H}), 2.63(\mathrm{~s}, 3 \mathrm{H}), 2.31(\mathrm{~m}, 2 \mathrm{H})$, $2.01(\mathrm{~m}, 2 \mathrm{H}) .{ }^{13} \mathrm{C}$ NMR CD $3 \mathrm{OD}(150 \mathrm{MHz}): \delta 166.7,157.8,157.5,154.8,140.3,136.2$, $130.2,126.7$ (q, $J=277.3 \mathrm{~Hz}), 122.4,122.0,118.3,114.9,114.7,113.1,109.5,94.5,55.0$, 53.6, 47.2, 41.2, 35.8 (q, $J=31.9 \mathrm{~Hz}), 30.0,16.1$. HRMS (ESI): $\left[\mathrm{M}+\mathrm{H}^{+}\right]$calculated 582.2006; found 582.2011.

Compounds 5, 6, 9, 10, 22, and 32 were obtained from synthesis on demand, with all compounds provided with the certificate of analysis and in addition fully characterized in house by HRMS and NMR. Characterization results of compounds 5, 6, 9, 10, 22, and 32 are the following.

1-(2-Hydroxy-3-methoxypropyl)-5-((4-((6-(2,2,2-trifluoroethyl)thieno[2,3d]pyrimidin-4-yl)amino)piperidin-1-yl)methyl)-1 H-indole-2-carbonitrile (5)- ${ }^{1} \mathrm{H}$ NMR DMSO- $d_{6}(600 \mathrm{MHz}): \delta 10.90$ (br s, 1H), 8.48 (br s, 1H), 8.39 (s, 1H), 7.89 (s, 1H), $7.73(\mathrm{~s}, 1 \mathrm{H}), 7.65(\mathrm{~m}, 1 \mathrm{H}), 7.47(\mathrm{~s}, 1 \mathrm{H}), 4.38(\mathrm{~m}, 1 \mathrm{H}), 4.32(\mathrm{~s}, 2 \mathrm{H}), 4.27(\mathrm{~m}, 1 \mathrm{H}), 4.21(\mathrm{~m}$, $1 \mathrm{H}), 4.04(\mathrm{q}, J=10.5 \mathrm{~Hz}, 2 \mathrm{H}), 3.92(\mathrm{~m}, 1 \mathrm{H}), 3.36(\mathrm{~m}, 2 \mathrm{H}), 3.29(\mathrm{~m}, 1 \mathrm{H}), 3.26(\mathrm{~s}, 3 \mathrm{H}), 3.06$ $(\mathrm{m}, 2 \mathrm{H}), 2.07(\mathrm{~m}, 2 \mathrm{H}), 1.98(\mathrm{~m}, 2 \mathrm{H}) .{ }^{13} \mathrm{C}$ NMR DMSO- $d_{6}(150 \mathrm{MHz}): \delta 155.4,137.8$, 128.4, 127.2 (q, $J=277.3 \mathrm{~Hz}), 125.6,125.5,124.6,122.4,121.6,116.3,113.6,113.2,111.8$, 111.1, 74.1, 68.2, 59.1, 58.5, 50.3, 48.8, 45.9, 33.6 (q, $J=31.9 \mathrm{~Hz}), 31.3,29.0,28.1,22.1$, 14.0. HRMS (ESI): $\left[\mathrm{M}+\mathrm{H}^{+}\right]$calculated 559.2098; found 559.2093.

1-(3-Hydroxy-2-isopropoxypropyl)-5-((4-((6-(2,2,2-trifluoroethyl)thieno[2,3d]pyrimidin-4-yl)amino)piperidin-1-yl)methyl)-1 H-indole-2-carbonitrile (6)- ${ }^{1} \mathrm{H}$ NMR DMSO- $d_{6}(600 \mathrm{MHz}): \delta 11.09(\mathrm{br}, 1 \mathrm{H}), 8.76(\mathrm{br}, 1 \mathrm{H}), 8.48(\mathrm{~s}, 1 \mathrm{H}), 7.94(\mathrm{~s}, 1 \mathrm{H}), 7.82$ (s, 1H), $7.71(\mathrm{~m}, 2 \mathrm{H}), 7.51(\mathrm{~s}, 1 \mathrm{H}), 4.52(\mathrm{~m}, 1 \mathrm{H}), 4.37(\mathrm{~s}, 2 \mathrm{H}), 4.34(\mathrm{~m}, 1 \mathrm{H}), 4.22(\mathrm{~m}, 1 \mathrm{H})$, $4.08(\mathrm{q}, J=10.5 \mathrm{~Hz}, 2 \mathrm{H}), 3.61(\mathrm{~m}, 1 \mathrm{H}), 3.50(\mathrm{~m}, 1 \mathrm{H}), 3.39(\mathrm{~m}, 2 \mathrm{H}), 3.24(\mathrm{~m}, 1 \mathrm{H}), 3.10(\mathrm{~m}$, $1 \mathrm{H}), 2.10(\mathrm{~m}, 4 \mathrm{H}), 0.95(\mathrm{~d}, J=6.2 \mathrm{~Hz}, 3 \mathrm{H}), 0.53(\mathrm{~d}, J=6.2 \mathrm{~Hz}, 3 \mathrm{H}) .{ }^{13} \mathrm{C}$ NMR DMSO- $d_{6}$ (150 MHz): $\delta 151.8,137.6,128.4,125.4$ (q, $J=277.3 \mathrm{~Hz}), 125.7,125.6,122.5,121.7$, $116.5,113.6,113.1,111.7,111.3,76.5,70.9,61.6,59.1,50.3,47.6,47.0,46.2,33.6$ (q, $J=$ $31.9 \mathrm{~Hz}), 28.0,22.8,21.4$. HRMS (ESI): $\left[\mathrm{M}+\mathrm{H}^{+}\right]$calculated 587.2411; found 587.2416.

1-((1H-1,2,3-Triazol-4-yl)methyl)-5-((4-((6-(2,2,2-trifluoroethyl)thieno[2,3d]pyrimidin-4-yl)amino)piperidin-1-yl)methyl)-1 $\mathrm{H}$-indole-2-carbonitrile (9)- ${ }^{1} \mathrm{H}$ NMR DMSO- $d_{6}(600 \mathrm{MHz}): \delta 11.1(\mathrm{br} \mathrm{s}, 1 \mathrm{H}), 8.83(\mathrm{br} \mathrm{s}, 1 \mathrm{H}), 8.50(\mathrm{~s}, 1 \mathrm{H}), 7.94(\mathrm{~s}, 1 \mathrm{H})$, 7.92 (br s, 1H), 7.87 (s, 1H), 7.85 (s, 1H), 7.83 (br s, 1H), $7.72(\mathrm{~m}, 2 \mathrm{H}), 7.57$ (s, 1H), 5.68 (s, 2H), $4.36(\mathrm{~s}, 2 \mathrm{H}), 4.10(\mathrm{q}, J=10.5 \mathrm{~Hz}, 2 \mathrm{H}), 3.41(\mathrm{~m}, 2 \mathrm{H}), 3.08(\mathrm{~m}, 2 \mathrm{H}), 2.08(\mathrm{~m}, 2 \mathrm{H}), 2.04$ $(\mathrm{m}, 2 \mathrm{H}) .{ }^{13} \mathrm{C}$ NMR DMSO- $d_{6}(150 \mathrm{MHz}): \delta 137.3,128.9,125.3(\mathrm{q}, J=277.3 \mathrm{~Hz}), 125.8$, $125.6,122.8,121.7,116.5,114.0,113.3,111.7,110.1,59.0,50.2,46.2,33.7$ (q, $J=31.9$ Hz), 28.0. HRMS (ESI): $\left[\mathrm{M}+\mathrm{H}^{+}\right]$calculated 552.1900; found 552.1909.

1-((1H-Pyrazol-4-yl)methyl)-5-((4-((6-(2,2,2-trifluoroethyl)-thieno[2,3d] pyrimidin-4-yl)amino)piperidin-1-yl)methyl)-1 $\mathrm{H}$-indole-2-carbonitrile (10)- ${ }^{1} \mathrm{H}$ NMR DMSO- $d_{6}(600 \mathrm{MHz}): \delta 10.89$ (br s, 1H), 8.61 (br s, 1H), 8.45 (s, 1H), $7.93(\mathrm{~s}, 1 \mathrm{H})$, $7.79(\mathrm{~s}, 1 \mathrm{H}), 7.70(\mathrm{~m}, 1 \mathrm{H}), 7.64(\mathrm{~m}, 2 \mathrm{H}), 7.55(\mathrm{~s}, 1 \mathrm{H}), 5.46(\mathrm{~s}, 2 \mathrm{H}), 4.36(\mathrm{~s}, 2 \mathrm{H}), 4.32(\mathrm{~m}$, $1 \mathrm{H}), 4.90(\mathrm{q}, J=10.5 \mathrm{~Hz}, 2 \mathrm{H}), 3.40(\mathrm{~m}, 2 \mathrm{H}), 3.08(\mathrm{~m}, 2 \mathrm{H}), 2.10(\mathrm{~m}, 2 \mathrm{H}), 2.02(\mathrm{~m}, 2 \mathrm{H}) .{ }^{13} \mathrm{C}$ NMR DMSO- $d_{6}(150 \mathrm{MHz}): \delta 137.0,128.8,125.8,125.6,125.2(\mathrm{q}, J=277.3 \mathrm{~Hz}), 122.7$, 
121.6, 116.4, 115.7, 113.9, 113.5, 111.7, 109.5, 59.1, 50.3, 46.0, 33.6 (q, $J=31.9 \mathrm{~Hz}$ ), 30.7, 28.1. HRMS (ESI): $\left[\mathrm{M}+\mathrm{H}^{+}\right]$calculated 551.1948; found 551.1957.

1-(2-Hydroxyethyl)-4-methyl-5-((4-((6-(2,2,2-trifluoroethyl)-thieno[2,3d] pyrimidin-4-yl)amino)piperidin-1-yl)methyl)-1 H-indole-2-carbonitrile (22)- ${ }^{1} \mathrm{H}$ NMR DMSO- $d_{6}(600 \mathrm{MHz}): \delta 10.90$ (br s, 1H), 9.10 (br s, 1H), $8.57(\mathrm{~s}, 1 \mathrm{H}), 7.90(\mathrm{~m}, 1 \mathrm{H})$, $7.76(\mathrm{~d}, J=8.2 \mathrm{~Hz}, 1 \mathrm{H}), 7.60(\mathrm{~s}, 1 \mathrm{H}), 7.56(\mathrm{~d}, J=8.2 \mathrm{~Hz}, 1 \mathrm{H}), 4.40(\mathrm{~m}, 3 \mathrm{H}), 4.12(\mathrm{q}, J=$ $10.5 \mathrm{~Hz}, 2 \mathrm{H}), 3.72(\mathrm{~m}, 2 \mathrm{H}), 3.42(\mathrm{~m}, 2 \mathrm{H}), 3.25(\mathrm{~m}, 2 \mathrm{H}), 2.64(\mathrm{~s}, 3 \mathrm{H}), 2.16(\mathrm{~m}, 2 \mathrm{H}), 2.09(\mathrm{~m}$, $2 \mathrm{H}) .{ }^{13} \mathrm{C}$ NMR DMSO- $d_{6}(150 \mathrm{MHz}): \delta 137.2,133.3,129.8,126.7,125.3$ (q, $J=277.3 \mathrm{~Hz}$ ), $121.9,120.1,116.6,113.8,112.6,110.0,109.3,59.8,56.1,50.4,48.0,46.5,33.6$ (q, $J=31.9$ $\mathrm{Hz}), 27.9,22.5,15.4$. HRMS (ESI): [M + $\left.\mathrm{H}^{+}\right]$calculated 515.1835; found 515.1829.

\section{1-((1H-1,2,3-Triazol-4-yl)methyl)-4-methyl-5-((4-((6-(2,2,2-} trifluoroethyl)thieno[2,3-d]pyrimidin-4-yl)amino)piperidin-1-yl)methyl)-1 Hindole-2-carbonitrile (32)— ${ }^{1} \mathrm{H}$ NMR DMSO- $d_{6}(600 \mathrm{MHz}): \delta 10.61$ (br s, $\left.1 \mathrm{H}\right), 8.70$ (br s, 1H), $8.48(\mathrm{~s}, 1 \mathrm{H}), 7.90(\mathrm{br} \mathrm{s}, 1 \mathrm{H}), 7.82(\mathrm{~m}, 1 \mathrm{H}), 7.76(\mathrm{~m}, 1 \mathrm{H}), 7.68(\mathrm{~m}, 2 \mathrm{H}), 5.66(\mathrm{~s}, 2 \mathrm{H})$, 4.39 (s, 2H), $4.37(\mathrm{~m}, 2 \mathrm{H}), 4.09$ (q, $J=10.5 \mathrm{~Hz}, 2 \mathrm{H}), 3.41(\mathrm{~m}, 2 \mathrm{H}), 3.32(\mathrm{~m}, 2 \mathrm{H}), 2.62(\mathrm{~s}$, $3 \mathrm{H}), 2.08(\mathrm{~m}, 4 \mathrm{H}) .{ }^{13} \mathrm{C}$ NMR DMSO- $d_{6}(150 \mathrm{MHz}): \delta 137.0,133.5,130.2,126.7,125.3(\mathrm{q}$, $J=277.3 \mathrm{~Hz}), 121.7,120.5,116.4,113.6,113.4,109.3,109.2,56.1,50.5,46.1,33.6$ (q, $J=$ $31.9 \mathrm{~Hz}), 30.7,28.1,15.5$. HRMS (ESI): [M + $\left.\mathrm{H}^{+}\right]$calculated 515.1835; found 515.1829.

\section{Supplementary Material}

Refer to Web version on PubMed Central for supplementary material.

\section{Acknowledgments}

The authors thank Drs. Szymon Klossowski and Felicia Gray for critical reading of this manuscript. This work was funded by the National Institutes of Health (NIH) Grant R01 (Grant 1R01CA160467) to J.G., a Leukemia and Lymphoma Society (LLS) TRP Grant 6116-12 to J.G., LLS Scholar (Grant 1215-14) to J.G., LLS TAP (Therapy Acceleration Program) to J.G., American Cancer Society Grant RSG-11-082-01-DMC to T.C. and Grant RSG-13-130-01-CDD to J.G., and the Department of Pathology, University of Michigan. Use of the Advanced Photon Source was supported by the U.S. Department of Energy, Office of Science, Office of Basic Energy Sciences under Contract DE-AC02-06CH11357. Use of the LS-CAT Sector 21 was supported by the Michigan Economic Development Corporation and the Michigan Technology Tri-Corridor for the support of this research program (Grant 085P1000817). The mouse work was performed under oversight of UCUCA at the University of Michigan.

\section{ABBREVIATIONS}

ALL acute lymphoblastic leukemia

AML acute myeloid leukemia

DIEA $\quad N, N$-diisopropylethylamine

FP fluorescence polarization

MLL mixed lineage leukemia

PPI protein-protein interaction 
SI selectivity index

TBDPS tert-butyldiphenylsilyl

NEAA nonessential amino acid

FBS fetal bovine serum

\section{References}

1. Yokoyama A, Somervaille TC, Smith KS, Rozenblatt-Rosen O, Meyerson M, Cleary ML. The menin tumor suppressor protein is an essential oncogenic cofactor for MLL-associated leukemogenesis. Cell. 2005; 123:207-218. [PubMed: 16239140]

2. Marschalek R. Mechanisms of leukemogenesis by MLL fusion proteins. Br J Haematol. 2011; 152:141-154. [PubMed: 21118195]

3. Tomizawa D, Koh K, Sato T, Kinukawa N, Morimoto A, Isoyama K, Kosaka Y, Oda T, Oda M, Hayashi Y, Eguchi M, Horibe K, Nakahata T, Mizutani S, Ishii E. Outcome of risk-based therapy for infant acute lymphoblastic leukemia with or without an MLL gene rearrangement, with emphasis on late effects: a final report of two consecutive studies, MLL96 and MLL98, of the Japan Infant Leukemia Study Group. Leukemia. 2007; 21:2258-2263. [PubMed: 17690691]

4. Slany RK. When epigenetics kills: MLL fusion proteins in leukemia. Hematol Oncol. 2005; 23:1-9. [PubMed: 16118769]

5. Popovic R, Zeleznik-Le NJ. MLL: how complex does it get? J Cell Biochem. 2005; 95:234-242. [PubMed: 15779005]

6. Dimartino JF, Cleary ML. Mll rearrangements in haematological malignancies: lessons from clinical and biological studies. Br J Haematol. 1999; 106:614-626. [PubMed: 10468849]

7. Hess JL. MLL: a histone methyltransferase disrupted in leukemia. Trends Mol Med. 2004; 10:500507. [PubMed: 15464450]

8. Krivtsov AV, Twomey D, Feng Z, Stubbs MC, Wang Y, Faber J, Levine JE, Wang J, Hahn WC, Gilliland DG, Golub TR, Armstrong SA. Transformation from committed progenitor to leukaemia stem cell initiated by MLL-AF9. Nature. 2006; 442:818-822. [PubMed: 16862118]

9. Grembecka J, Belcher AM, Hartley T, Cierpicki T. Molecular basis of the mixed lineage leukemiamenin interaction: implications for targeting mixed lineage leukemias. J Biol Chem. 2010; 285:40690-40698. [PubMed: 20961854]

10. Yokoyama A, Cleary ML. Menin critically links MLL proteins with LEDGF on cancer-associated target genes. Cancer Cell. 2008; 14:36-46. [PubMed: 18598942]

11. Caslini C, Yang Z, El-Osta M, Milne TA, Slany RK, Hess JL. Interaction of MLL amino terminal sequences with menin is required for transformation. Cancer Res. 2007; 67:7275-7283. [PubMed: 17671196]

12. Shi A, Murai MJ, He S, Lund G, Hartley T, Purohit T, Reddy G, Chruszcz M, Grembecka J, Cierpicki T. Structural insights into inhibition of the bivalent menin-MLL interaction by small molecules in leukemia. Blood. 2012; 120:4461-4469. [PubMed: 22936661]

13. Murai MJ, Chruszcz M, Reddy G, Grembecka J, Cierpicki T. Crystal structure of menin reveals binding site for mixed lineage leukemia (MLL) protein. J Biol Chem. 2011; 286:31742-31748. [PubMed: 21757704]

14. Grembecka J, He S, Shi A, Purohit T, Muntean AG, Sorenson RJ, Showalter HD, Murai MJ, Belcher AM, Hartley T, Hess JL, Cierpicki T. Menin-MLL inhibitors reverse oncogenic activity of MLL fusion proteins in leukemia. Nat Chem Biol. 2012; 8:277-284. [PubMed: 22286128]

15. He S, Senter TJ, Pollock J, Han C, Upadhyay SK, Purohit T, Gogliotti RD, Lindsley CW, Cierpicki T, Stauffer SR, Grembecka J. High-affinity small-molecule inhibitors of the menin-mixed lineage leukemia (MLL) interaction closely mimic a natural protein-protein interaction. J Med Chem. 2014; 57:1543-1556. [PubMed: 24472025]

16. Borkin D, He S, Miao H, Kempinska K, Pollock J, Chase J, Purohit T, Malik B, Zhao T, Wang J, Wen B, Zong H, Jones M, Danet-Desnoyers G, Guzman ML, Talpaz M, Bixby DL, Sun D, Hess 
JL, Muntean AG, Maillard I, Cierpicki T, Grembecka J. Pharmacologic inhibition of the MeninMLL interaction blocks progression of MLL leukemia in vivo. Cancer Cell. 2015; 27:589-602. [PubMed: 25817203]

17. Kar G, Gursoy A, Keskin O. Human cancer protein-protein interaction network: a structural perspective. PLoS Comput Biol. 2009; 5:e1000601. [PubMed: 20011507]

18. Buchwald P. Small-molecule protein-protein interaction inhibitors: therapeutic potential in light of molecular size, chemical space, and ligand binding efficiency considerations. IUBMB Life. 2010; 62:724-731. [PubMed: 20979208]

19. Fry DC. Protein-protein interactions as targets for small molecule drug discovery. Biopolymers. 2006; 84:535-552. [PubMed: 17009316]

20. Azzarito V, Long K, Murphy NS, Wilson AJ. Inhibition of alpha-helix-mediated protein-protein interactions using designed molecules. Nat Chem. 2013; 5:161-173. [PubMed: 23422557]

21. Arkin MR, Whitty A. The road less traveled: modulating signal transduction enzymes by inhibiting their protein-protein interactions. Curr Opin Chem Biol. 2009; 13:284-290. [PubMed: 19553156]

22. Morelli X, Bourgeas R, Roche P. Chemical and structural lessons from recent successes in proteinprotein interaction inhibition (2P2I). Curr Opin Chem Biol. 2011; 15:475-481. [PubMed: 21684802]

23. Smith MC, Gestwicki JE. Features of protein-protein interactions that translate into potent inhibitors: topology, surface area and affinity. Expert Rev Mol Med. 2012; 14:e16. [PubMed: 22831787]

24. Wells JA, McClendon CL. Reaching for high-hanging fruit in drug discovery at protein-protein interfaces. Nature. 2007; 450:1001-1009. [PubMed: 18075579]

25. Cierpicki T, Grembecka J. Targeting protein-protein interactions in hematologic malignancies: still a challenge or a great opportunity for future therapies? Immunol Rev. 2015; 263:279-301. [PubMed: 25510283]

26. Nero TL, Morton CJ, Holien JK, Wielens J, Parker MW. Oncogenic protein interfaces: small molecules, big challenges. Nat Rev Cancer. 2014; 14:248-262. [PubMed: 24622521]

27. Bai L, Wang S. Targeting apoptosis pathways for new cancer therapeutics. Annu Rev Med. 2014; 65:139-155. [PubMed: 24188661]

28. He S, Malik B, Borkin D, Miao H, Shukla S, Kempinska K, Purohit T, Wang J, Chen L, Parkin B, Malek SN, Danet-Desnoyers G, Muntean AG, Cierpicki T, Grembecka J. Menin-MLL inhibitors block oncogenic transformation by MLL-fusion proteins in a fusion partner-independent manner. Leukemia. 2015; doi: 10.1038/leu.2015.144

29. Puterova Z, Krutosíkova A, Veghc D. Gewald reaction: synthesis, properties and applications of substituted 2-aminothiophenes. ARKIVOC. 2010; (i):209-246.

30. Gribble GW. Recent developments in indole ring synthesis-methodology and applications. J Chem Soc, Perkin Trans. 2000; 1:1045-1075.

31. Moyer MP, Shiurba JF, Rapoport H. Metal-Halogen Exchange of Bromoindoles. A Route to Substituted Indoles. J Org Chem. 1986; 51:5106-5110.

32. Stokes BJ, Dong H, Leslie BE, Pumphrey AL, Driver TG. Intramolecular C-H amination reactions: exploitation of the Rh(2)(II)-catalyzed decomposition of azidoacrylates. J Am Chem Soc. 2007; 129:7500-7501. [PubMed: 17523647]

33. Higueruelo AP, Schreyer A, Bickerton GR, Pitt WR, Groom CR, Blundell TL. Atomic interactions and profile of small molecules disrupting protein-protein interfaces: the TIMBAL database. Chem Biol Drug Des. 2009; 74:457-467. [PubMed: 19811506]

34. Otwinowski, Z.; Minor, W. Processing of X-ray diffraction data. In: Carter, CW., Jr; Sweet, RM., editors. Macromolecular Crystallography, Part A. Vol. 276. Academic Press; San Diego, CA: 1997. p. 307-326.Methods in Enzymology

35. Murshudov GN, Vagin AA, Dodson EJ. Refinement of macromolecular structures by the maximum-likelihood method. Acta Crystallogr, Sect D: Biol Crystallogr. 1997; 53:240-255. [PubMed: 15299926]

36. Emsley P, Cowtan K. Coot: model-building tools for molecular graphics. Acta Crystallogr, Sect D: Biol Crystallogr. 2004; 60:2126-2132. [PubMed: 15572765] 
37. The CCP4 suite: programs for protein crystallography. Acta Crystallogr, Sect D: Biol Crystallogr. 1994; 50:760-763. DOI: 10.1107/S0907444994003112 [PubMed: 15299374]

38. Davis IW, Leaver-Fay A, Chen VB, Block JN, Kapral GJ, Wang X, Murray LW, Arendall WB 3rd, Snoeyink J, Richardson JS, Richardson DC. MolProbity: all-atom contacts and structure validation for proteins and nucleic acids. Nucleic Acids Res. 2007; 35:W375-383. [PubMed: 17452350]

39. Yang H, Guranovic V, Dutta S, Feng Z, Berman HM, Westbrook JD. Automated and accurate deposition of structures solved by X-ray diffraction to the Protein Data Bank. Acta Crystallogr, Sect D: Biol Crystallogr. 2004; 60:1833-1839. [PubMed: 15388930]

40. Muntean AG, Tan J, Sitwala K, Huang Y, Bronstein J, Connelly JA, Basrur V, Elenitoba-Johnson KS, Hess JL. The PAF complex synergizes with MLL fusion proteins at HOX loci to promote leukemogenesis. Cancer Cell. 2010; 17:609-621. [PubMed: 20541477] 

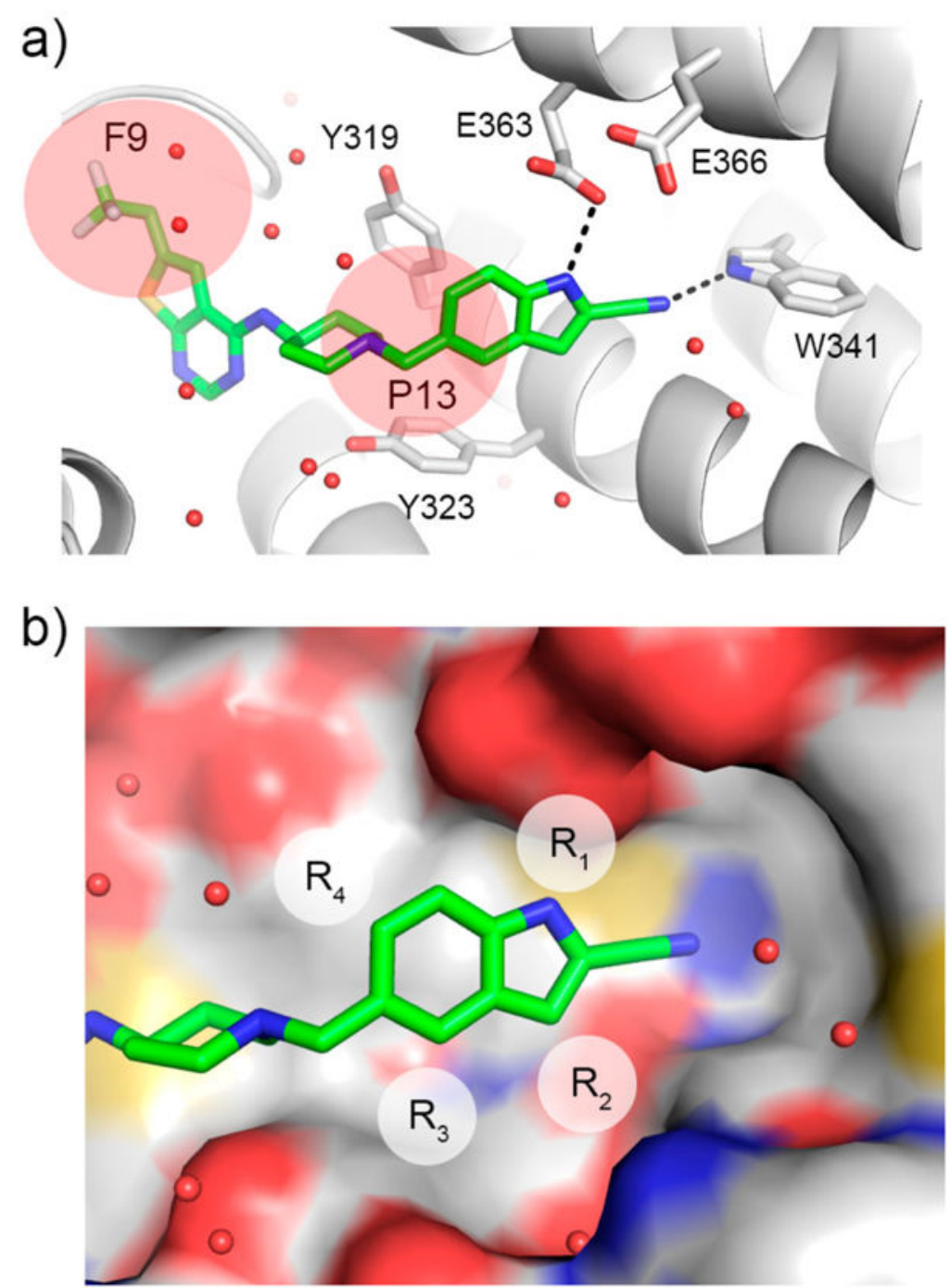

Figure 1.

Compound 1 represents a good pharmacophore for development of menin-MLL inhibitors. (a) Binding mode of $\mathbf{1}$ to menin from the crystal structure of $\mathbf{1}$ bound to menin (4X5Z in PDB). Protein is shown in ribbon representation, and key menin residues involved in interactions with $\mathbf{1}$ are shown as sticks. Compound $\mathbf{1}$ is shown in stick representation with colors corresponding to the atom type (green, carbons; dark blue, nitrogens; yellow, sulfur; light blue, fluorine). Dashed lines represent hydrogen bonds between 1 and menin. Water molecules are represented as red spheres. $\mathrm{P} 9$ and $\mathrm{P} 13$ pockets are marked as pink spheres. (b) Crystal structure of menin-1 (green carbons) with substitution sites on indole of $\mathbf{1}$ explored for optimization marked as $\mathrm{R}_{1}, \mathrm{R}_{2}, \mathrm{R}_{3}$, and $\mathrm{R}_{4}$. Menin is shown in surface representation with atoms colored according to the atom type (red, oxygens; blue, nitrogens; yellow, sulfur; gray, carbons). 
a)

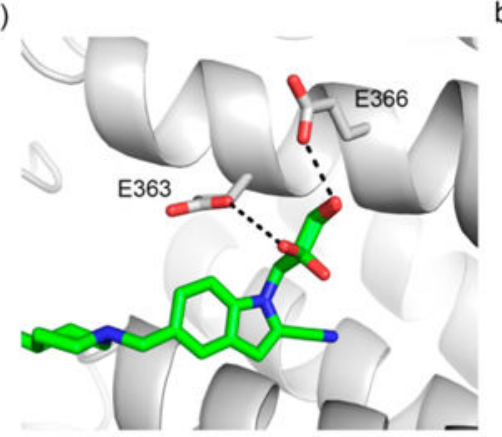

b)

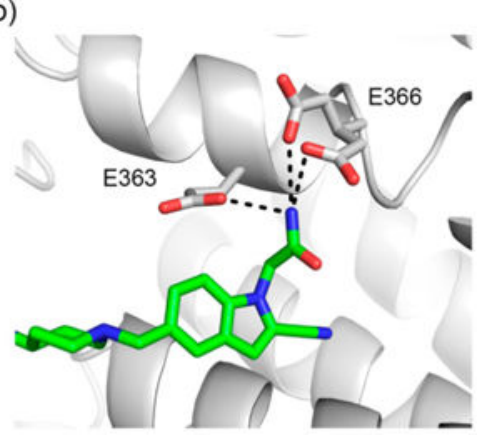

Figure 2.

Structure-based optimization of polar interactions with menin. (a) Crystal structure of the menin-3-(RS) complex (PDB code 5DB0) demonstrating binding of both enantiomers of 3$(\boldsymbol{R S})$ to menin. Hydrogen bonds with Glu363 and Glu366 are marked. (b) Crystal structure of menin-7 complex (PDB code 5DB2) showing the interactions of the amide group of 7 with Glu363 and Glu366 on menin. The side chain of Glu366 exists in two conformations. 
a)

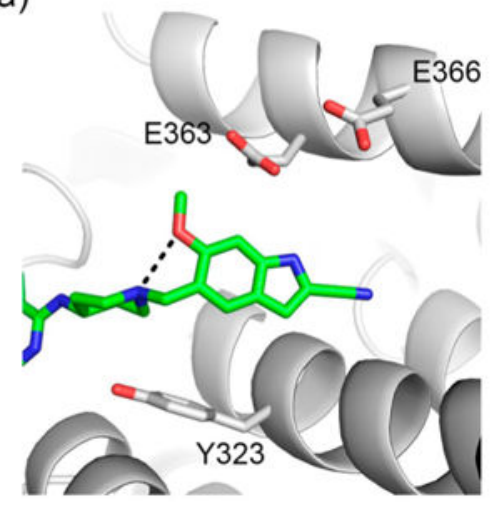

b)

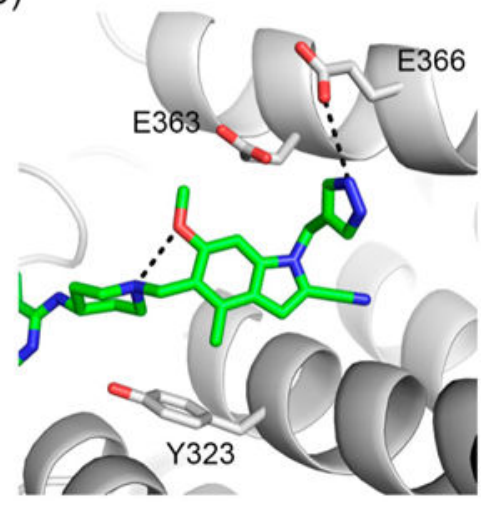

Figure 3.

Structure-based optimization of $\mathrm{R}_{1}$ and $\mathrm{R}_{4}$ substituents. (a) Crystal structure of menin-18 complex (PDB code 5DB1) demonstrating intramolecular hydrogen bond between the methoxy group and nitrogen in the piperidine ring of 18. (b) Binding mode of triple substituted compound $\mathbf{3 1}$ to menin based on the crystal structure of the complex (PDB code 5DB3). 
a)

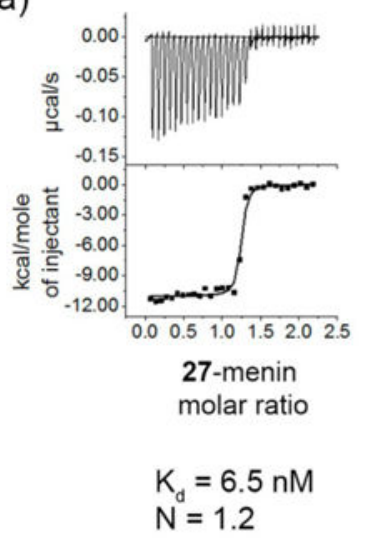

b)

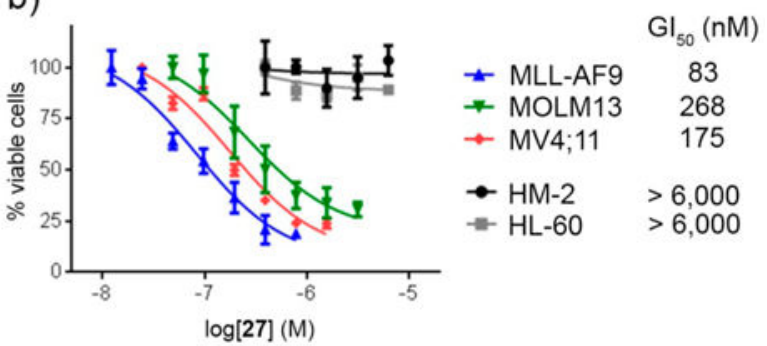

c)

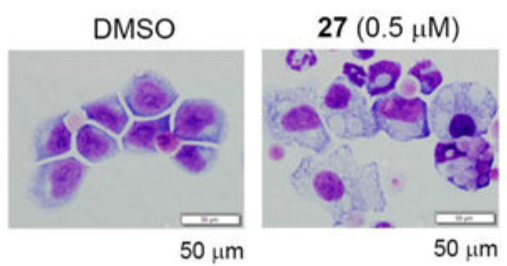

e)

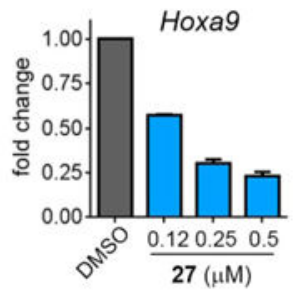

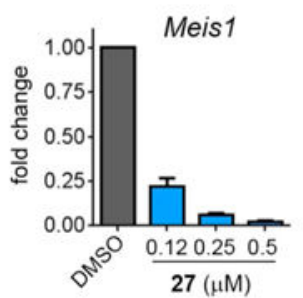

Figure 4.

Binding to menin and cellular activity of compound 27. (a) Binding isotherm from the ITC experiment for $\mathbf{2 7}$ showing its direct binding to menin. (b) Titration curves from the MTT cell viability assay performed for $\mathbf{2 7}$ after 7 days of treatment of MLL-AF9 or Hoxa9/Meis1 (HM-2) transformed murine bone marrow cells as well as human MLL leukemia cell lines (MV4;11 and MOLM-13) and control cell line HL-60 (non-MLL leukemia cell line). Cell growth inhibition $\left(\mathrm{GI}_{50}\right)$ values are provided for MLL leukemia cell lines. Data represent mean values of quadruplicates \pm SD. The experiments were performed 3 times. (c) WrightGiemsa stained cytospins for MLL-AF9 transformed murine bone marrow cells (BMCs) after 7 days of treatment with 27. Black line represents the scale bar $(50 \mu \mathrm{m})$. (d) Quantification of Itgam expression in MLL-AF9 transformed murine bone marrow cells after 6 days of treatment with $\mathbf{2 7}$ as detected by quantitative real-time PCR (qRT-PCR), mean $\pm \mathrm{SD}, n=2$. Expression of Itgam was normalized to $18 \mathrm{~S}$ rRNA and referenced to DMSO-treated cells. (e) qRT-PCR performed in MLL-AF9 transformed BMCs after 6 days of treatment with 27. Expression of Hoxa9 and Meis1 was normalized to $\beta$-actin and referenced to DMSO-treated cells, mean $\pm \mathrm{SD}, n=2$. 


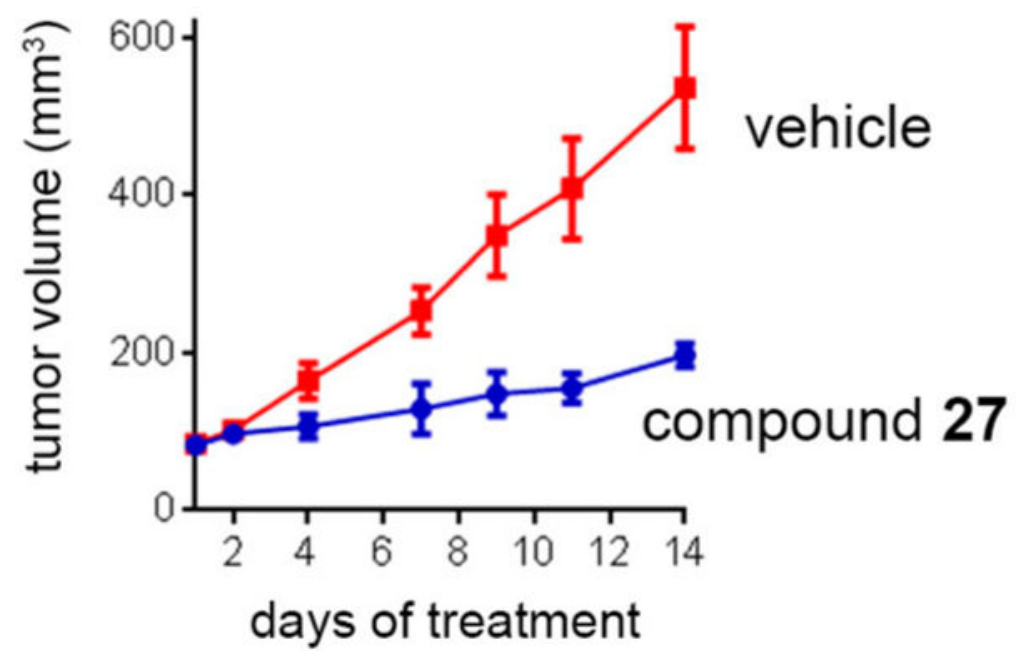

Figure 5.

In vivo inhibition of tumor growth by compound 27. 27 inhibits tumor growth in MV4;11 subcutaneous model of MLL leukemia developed in CB17 SCID mice after injecting $0.5 \times$ $10^{7} \mathrm{MV} 4 ; 11$ cells, $n=9$ per group. Mice were treated once daily with 27 (45 mg/kg) or vehicle via ip, resulting in substantial reduction of the tumor volume $(p<0.001)$. Error bars represent SEM. 

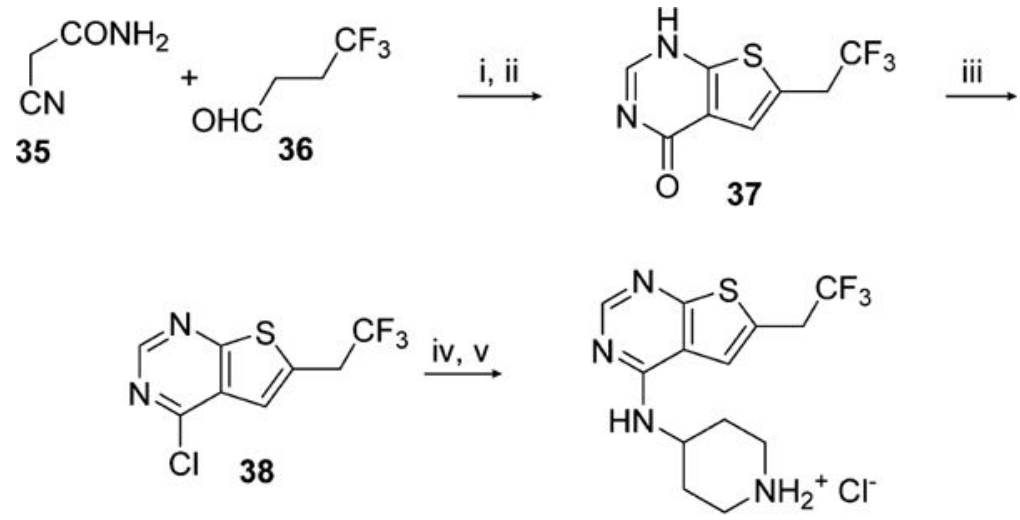

39

Scheme 1. Synthesis of Compound 39 $a$

${ }^{a}$ Reagents and conditions: (i) S, Et $3 \mathrm{~N}, \mathrm{DMF}, \mathrm{rt}, 24 \mathrm{~h}$; (ii) $\mathrm{AcOH}$, (EtO) ${ }_{3} \mathrm{CH}$, reflux, 4 h, $76 \%$ (2 steps); (iii) $\mathrm{POCl}_{3}$, reflux, 3 h, 92\%; (iv) tert-butyl 4-aminopiperidine-1-carboxylate, DIEA, IPA, reflux, 12 h; (v) HCl, dioxane, rt, overnight, 64\% (2 steps). 

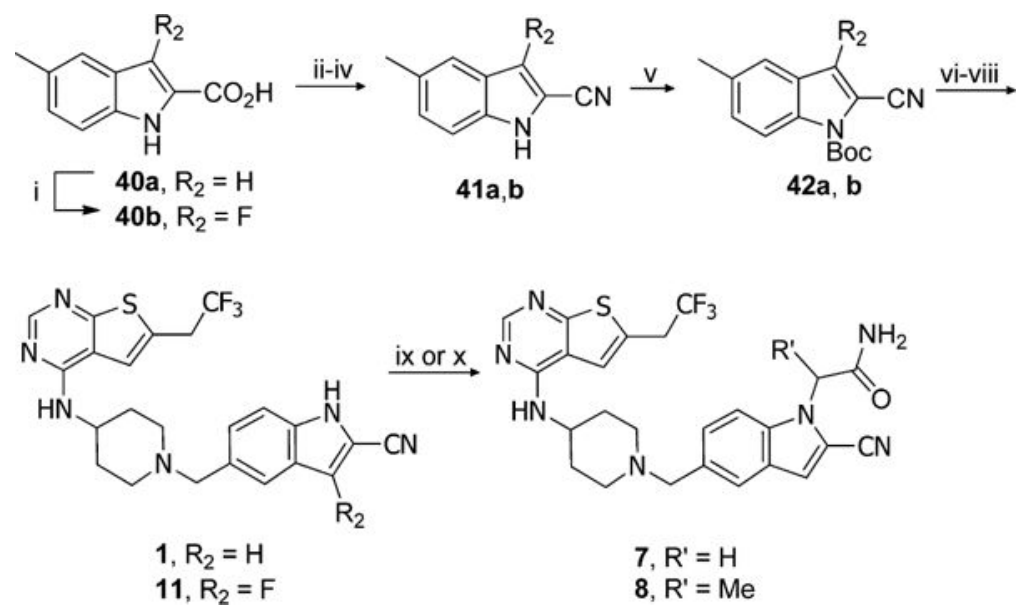

Scheme 2. Synthesis of Compounds $1,7,8$, and $11^{a}$

${ }^{a}$ Reagents and conditions: (i) 1-chloromethyl-4-fluoro-1,4-diazoniabicyclo[2.2.2]octane bis(tetrafluoroborate), $\mathrm{CH}_{3} \mathrm{CN}$, reflux, $12 \mathrm{~h}, 17 \%$; (ii) $\mathrm{SOCl}_{2}, \mathrm{CHCl}_{3}$, reflux, $2 \mathrm{~h}$; (iii) $\mathrm{NH}_{3} \cdot \mathrm{H}_{2} \mathrm{O}$, rt, $2 \mathrm{~h}$; (iv) $\mathrm{POCl}_{3}, \mathrm{CHCl}_{3}$, reflux, 4 h, 44-55\% (3 steps); (v) Boc $2 \mathrm{O}$, DMAP, $\mathrm{CH}_{3} \mathrm{CN}$, rt, $1 \mathrm{~h}, 79-83 \%$; (vi) NBS, AIBN, $\mathrm{CCl}_{4}$, reflux, $2 \mathrm{~h}$; (vii) 39, DIEA, DCM, $18 \mathrm{~h}$; (viii) $\mathrm{SnCl}_{4}, \mathrm{CH}_{3} \mathrm{CN}, 0{ }^{\circ} \mathrm{C}$ to rt, $0.5 \mathrm{~h}, 34-53 \%$ (3 steps); (ix) 2-bromoacetamide, $\mathrm{Cs}_{2} \mathrm{CO}_{3}$, DMF, rt, 4 h, $40 \%$ of 7; (x) 2-bromopropionamide, $\mathrm{Cs}_{2} \mathrm{CO}_{3}$, DMF, rt, 4 h, $27 \%$ of 8. 

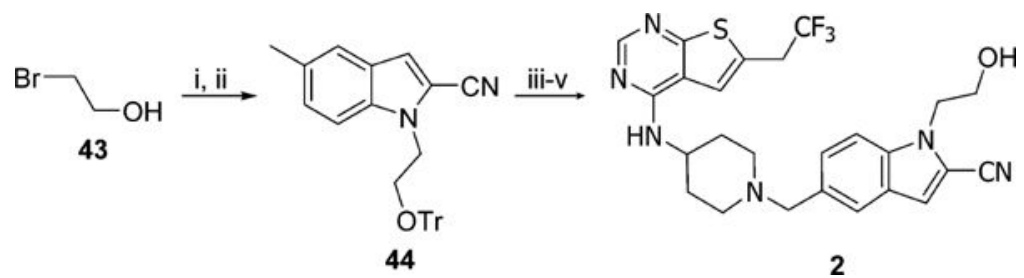

Scheme 3. Synthesis of Compound $2^{a}$

${ }^{a}$ Reagents and conditions: (i) TrCl, DMAP, $\mathrm{Et}_{3} \mathrm{~N}$, DCM, rt, 24 h, 96\%; (ii) 41a, NaH, DMF, rt to $60{ }^{\circ} \mathrm{C}$, overnight, $81 \%$; (iii) NBS, AIBN, $\mathrm{CCl}_{4}$, reflux, $2 \mathrm{~h}$; (iv) 39, DIEA, DCM, 5 h;

(v) $\mathrm{HCl}, \mathrm{MeOH}, \mathrm{rt}, 1 \mathrm{~h}, 42 \%$ (3 steps). 


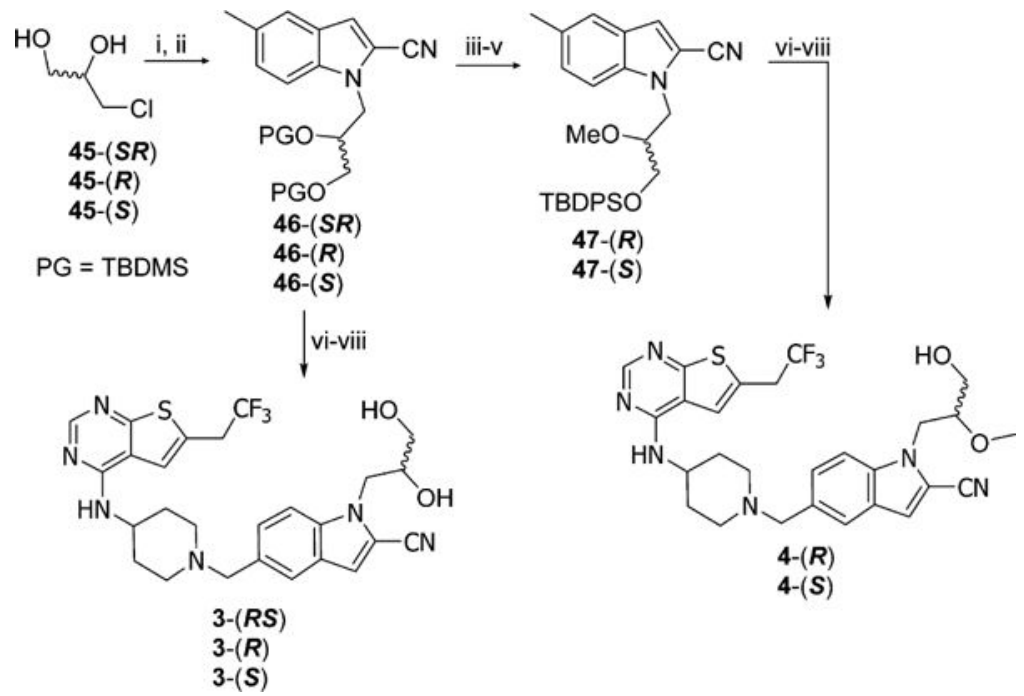

Scheme 4. Synthesis of Compounds 3-(RS), 3-(R), 3-(S), 4-(R), and 4-(S) ${ }^{a}$

${ }^{a}$ Reagents and conditions: (i) TBSCl, imidazole, DCM, rt, overnight, 84\%; (ii) 41a, NaH, DMF, rt, 2 h, 49\%; (iii) HCl, MeOH, rt, 4 h; (iv) TBDPSCl, imidazole, DCM, rt, 1 h; (v) $\mathrm{NaH}, \mathrm{MeI}, \mathrm{THF}, \mathrm{rt}, 1 \mathrm{~h}, 11 \%$ (3 steps); (vi) NBS, AIBN, $\mathrm{CCl}_{4}$, reflux, 2 h; (vii) 39, DIEA, DCM, 5 h; (vii) $\mathrm{HCl}, \mathrm{MeOH}, \mathrm{rt}, 1 \mathrm{~h}, 24-58 \%$ (3 steps). 


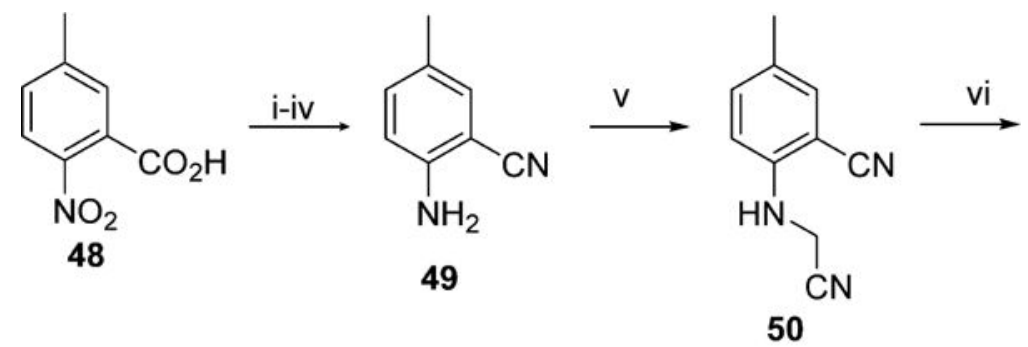

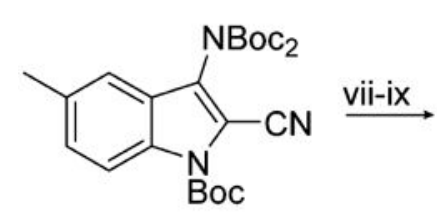

51<smiles>N#Cc1[nH]c2ccc(CN3CCC(Nc4ncnc5sc(CC(F)(F)F)cc45)CC3)cc2c1N</smiles>

Scheme 5. Synthesis of Compound $12^{a}$

${ }^{a}$ Reagents and conditions: (i) $\mathrm{SOCl}_{2}, \mathrm{CHCl}_{3}$, reflux, $3 \mathrm{~h}$; (ii) $\mathrm{NH}_{3} \cdot \mathrm{H} 2 \mathrm{O}$, rt, $2 \mathrm{~h}$; (iii) $\mathrm{POCl}_{3}$, $\mathrm{CHCl}_{3}$, reflux, $4 \mathrm{~h}$; (iv) $\mathrm{SnCl}_{2}$, EtOH, reflux, $1 \mathrm{~h}, 18 \%$ (4 steps); (v) paraformaldehyde, $\mathrm{KCN}, \mathrm{ZnCl}_{2}, \mathrm{AcOH}, 60{ }^{\circ} \mathrm{C}, 6$ h, 33\%; (vi) $\mathrm{Boc}_{2} \mathrm{O}$, DMAP, DMF, rt, 4 h, $25 \%$ (2 steps); (vii) $\mathrm{NBS}, \mathrm{AIBN}, \mathrm{CCl}_{4}$, reflux, $2 \mathrm{~h}$; (viii) 39, DIEA, DCM, $5 \mathrm{~h}$; (ix) $\mathrm{SnCl}_{4}, \mathrm{CH}_{3} \mathrm{CN}, 0{ }^{\circ} \mathrm{C}$ to rt, $0.5 \mathrm{~h}, 19 \%$ (3 steps). 


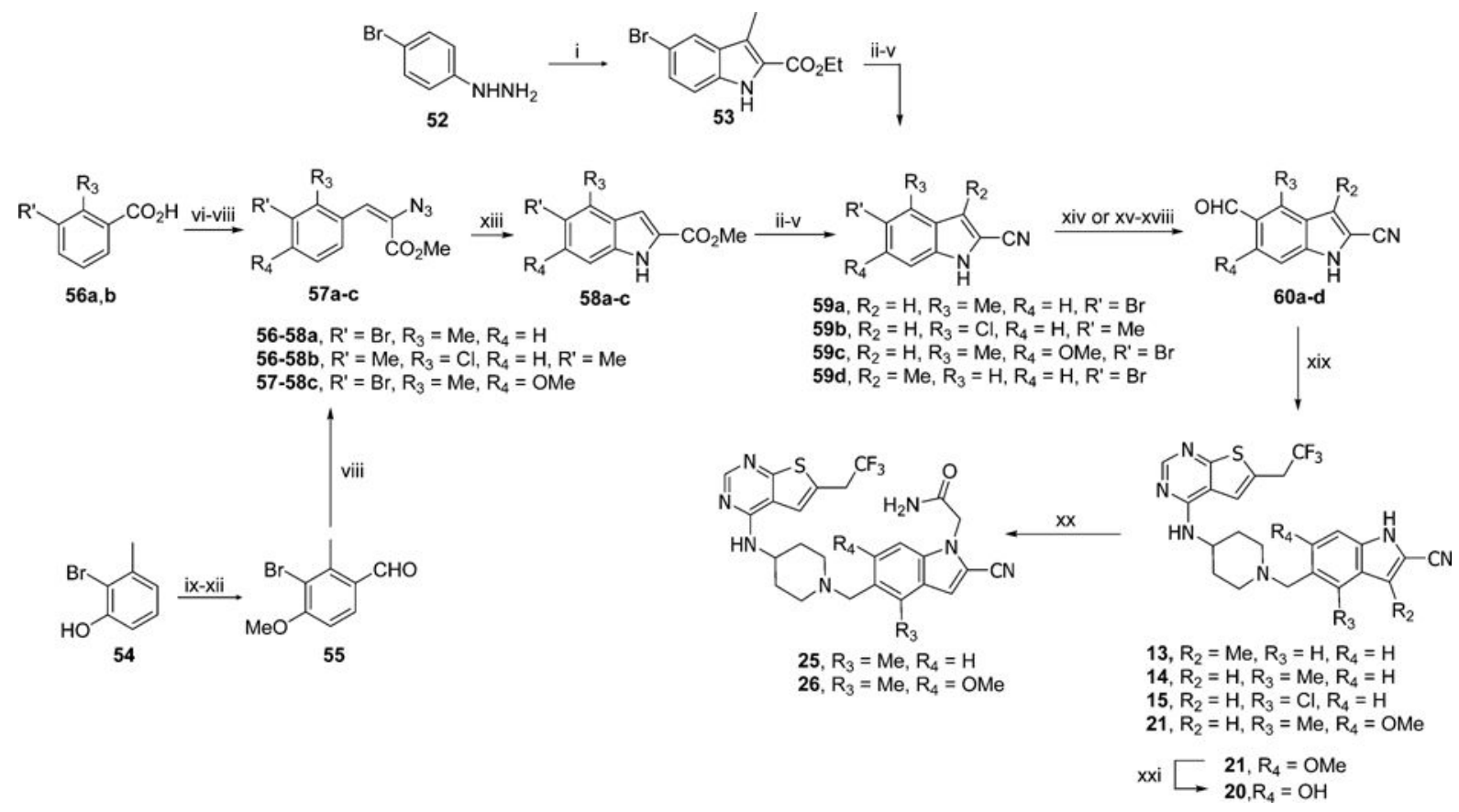

Scheme 6. Synthesis of Compounds 13-15, 20, 21, 25, and $26^{a}$

${ }^{a}$ Reagents and conditions: (i) 2-oxobutyric acid, $\mathrm{H}_{2} \mathrm{SO}_{4}$, EtOH, reflux, 8 h, 58\%; (ii) $\mathrm{KOH}$, $\mathrm{MeOH}$, reflux, $3 \mathrm{~h}$; (iii) oxalyl chloride, DCM, rt, 1 h; (iv) $\mathrm{NH}_{3} \cdot \mathrm{H}_{2} \mathrm{O}$, rt, $2 \mathrm{~h}$; (v) $\mathrm{POCl}_{3}$, $\mathrm{CHCl}_{3}$, reflux, $4 \mathrm{~h}, 56-96 \%$ (4 steps); (vi) LAH, THF, $0{ }^{\circ} \mathrm{C}$ to rt, $3 \mathrm{~h}, 80-97 \%$; (vii) PCC, DCM, rt, 5 h, 78-86\%; (viii) methyl azidoacetate, $\mathrm{MeONa}, \mathrm{MeOH},-15$ to $4{ }^{\circ} \mathrm{C}$, overnight 73-83\%; (ix) TBDPSCl, imidazole, DCM, rt, 2 h; (x) NIS, TFA, $\mathrm{CH}_{3} \mathrm{CN}, 50{ }^{\circ} \mathrm{C}, 12$ h, $92 \%$ (2 steps); (xi) BuLi, DMF, THF, -78 to $0{ }^{\circ} \mathrm{C}, 2 \mathrm{~h}$; (xii) MeI, $\mathrm{Me}_{2} \mathrm{CO}$, reflux, $2 \mathrm{~h}, 87 \%$ (2 steps); (xiii) (synthesis of 60a,c,d) xylene, reflux, 0.2 h, 50-81\%; (xiv) KH, $t$-BuLi, DMF, THF, -90 to $0{ }^{\circ} \mathrm{C}, 2 \mathrm{~h}, 32-89 \%$; (xv) (synthesis of $60 \mathrm{~b}$ ) $\mathrm{Boc}_{2} \mathrm{O}, \mathrm{DMAP}, \mathrm{CH}_{3} \mathrm{CN}, \mathrm{rt}, 1 \mathrm{~h}$, 96\%; (xvi) 2.2 equiv of NBS, AIBN, $\mathrm{CCl}_{4}$, reflux, 5 h; (xvii) $\mathrm{Ag}_{2} \mathrm{CO}_{3}, \mathrm{Me}_{2} \mathrm{CO} / \mathrm{H}_{2} \mathrm{O}$, rt, 24 h, 60\% (2 steps); (xviii) TFA, DCM, rt, 1 h, 81\%; (ix) 39, $\mathrm{Et}_{3} \mathrm{~N}, \mathrm{NaBH}(\mathrm{OAc})_{3}, \mathrm{DCM}, \mathrm{rt}$, overnight, 28-93\%; (xx) 2-bromoacetamide, $\mathrm{Cs}_{2} \mathrm{CO}_{3}$, DMF, rt, 4 h, 25-37\%; (xxi) $\mathrm{BBr}_{3}$, DCM, rt, 24 h, $68 \%$. 

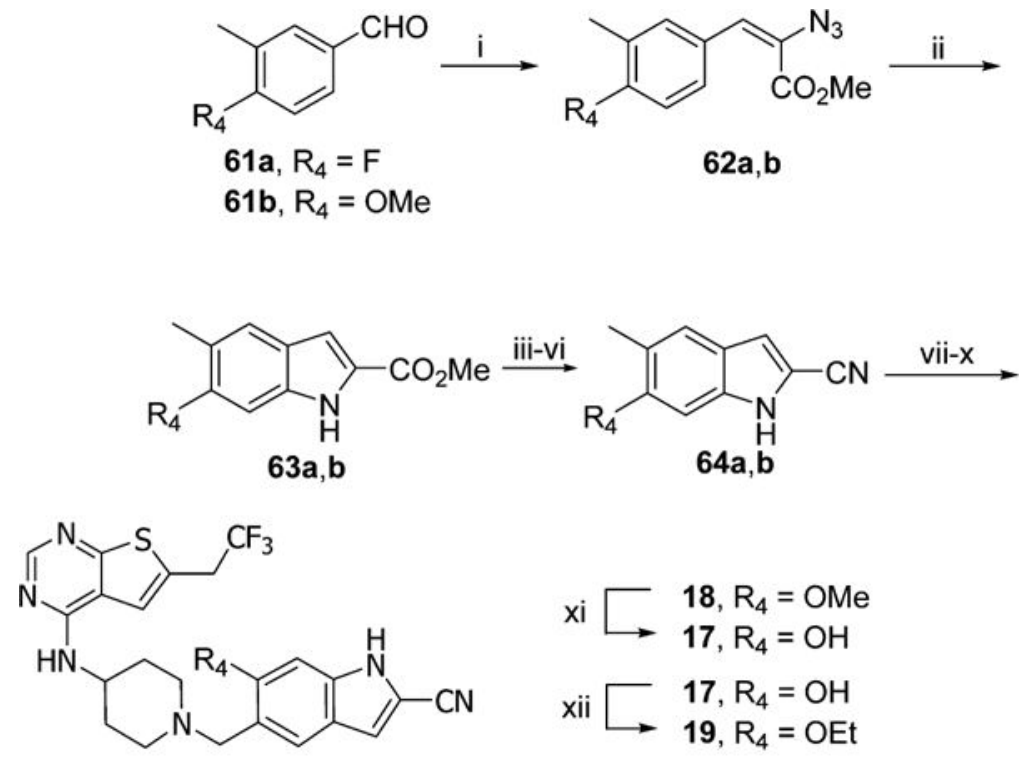

$$
\begin{aligned}
& \text { 16, } R_{4}=F \\
& 18, R_{4}=O M e
\end{aligned}
$$

\section{Scheme 7. Synthesis of Compounds 16-19 ${ }^{a}$}

${ }^{a}$ Reagents and conditions: (i) methyl azidoacetate, $\mathrm{MeONa}, \mathrm{MeOH},-15$ to $4{ }^{\circ} \mathrm{C}, 60-65 \%$;

(ii) $\mathrm{Rh}_{2}\left(\mathrm{CF}_{3} \mathrm{CO}_{2}\right)_{4}$, toluene, $50{ }^{\circ} \mathrm{C}, 24 \mathrm{~h}, 33-75 \%$; (iii) $\mathrm{KOH}, \mathrm{MeOH}$, reflux, $3 \mathrm{~h}$; (iv) oxalyl chloride, DCM, rt, $1 \mathrm{~h}$; (v) $\mathrm{NH}_{3} \cdot \mathrm{H}_{2} \mathrm{O}$, rt, 2 h; (vi) $\mathrm{POCl}_{3}, \mathrm{CHCl}_{3}$, reflux, $4 \mathrm{~h}, 58-62 \%$ (4 steps); (vii) $\mathrm{Boc}_{2} \mathrm{O}, \mathrm{CH}_{3} \mathrm{CN}$, rt, $1 \mathrm{~h}$; (viii) NBS, $\mathrm{AIBN}, \mathrm{CCl}_{4}$, reflux, $2 \mathrm{~h}$; (ix) 39, DIEA, DCM, $5 \mathrm{~h}$; (x) $\mathrm{SnCl}_{4}, \mathrm{CH}_{3} \mathrm{CN}, 0{ }^{\circ} \mathrm{C}$ to rt, $0.5 \mathrm{~h}, 50-77 \%$ (4 steps); (xi) $\mathrm{BBr}_{3}, \mathrm{DCM}, \mathrm{rt}, 24 \mathrm{~h}$, $56 \%$; (xii) EtI, $\mathrm{K}_{2} \mathrm{CO}_{3}, \mathrm{CH}_{3} \mathrm{CN}$, rt, 24 h, $61 \%$. 


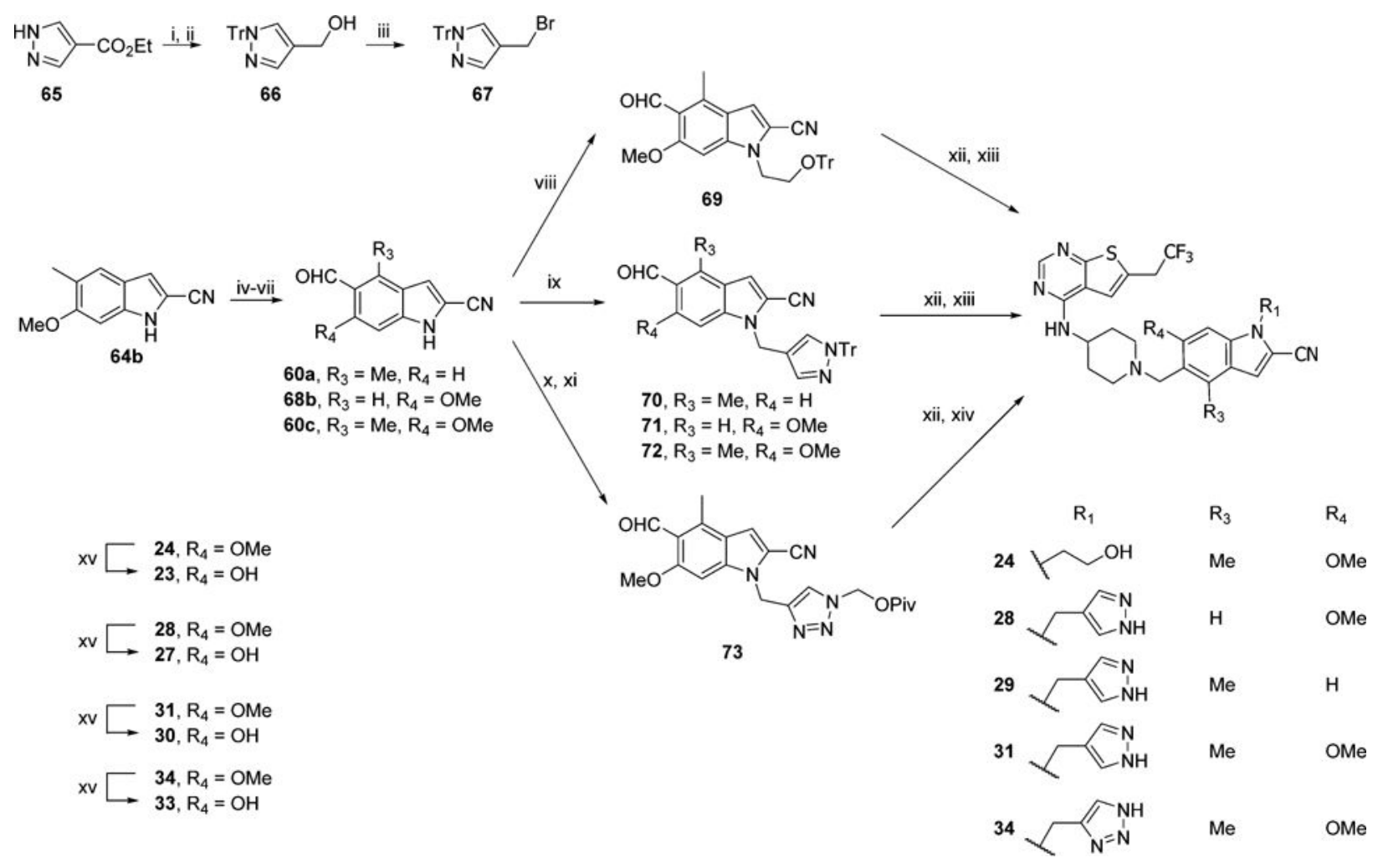

Scheme 8. Synthesis of Compounds 23, 24, 27-31, 33, and 34 ${ }^{a}$

${ }^{a}$ Reagents and conditions: (i) $t$-BuOK, TrCl, DMF, rt, $2 \mathrm{~h}$; (ii) LAH, THF, $0{ }^{\circ} \mathrm{C}$ to $\mathrm{rt}, 2 \mathrm{~h}$, 97\% (2 steps); (iii) NBS, $\mathrm{PPh}_{3}$, DCM, rt, 0.5 h, 79\%; (iv) $\mathrm{Boc}_{2} \mathrm{O}, \mathrm{DMAP}, \mathrm{CH}_{3} \mathrm{CN}, \mathrm{rt}, 1 \mathrm{~h}$; (v) 2.2 equiv of NBS, AIBN, $\mathrm{CCl}_{4}$, reflux, $5 \mathrm{~h}$; (vi) $\mathrm{Ag}_{2} \mathrm{CO}_{3}, \mathrm{Me}_{2} \mathrm{CO} / \mathrm{H}_{2} \mathrm{O}$, rt, $24 \mathrm{~h}$ (2 steps); (vii) TFA, DCM, rt, 1 h, 38\% (4 steps); (viii) $\mathrm{BrCH}_{2} \mathrm{CH}_{2} \mathrm{OTr}, \mathrm{Cs}_{2} \mathrm{CO}_{3}$, DMF, rt, $2 \mathrm{~h}, 50 \%$; (ix) 67, $\mathrm{Cs}_{2} \mathrm{CO}_{3}$, DMF, rt, $0.5 \mathrm{~h}, 82-94 \%$; (x) propargyl bromide, $\mathrm{Cs}_{2} \mathrm{CO}_{3}$, DMF, rt, 4 h; (xi) $t$ - $\mathrm{BuCO}_{2} \mathrm{CH}_{2} \mathrm{~N}_{3}, \mathrm{CuSO}_{4}$, sodium ascorbate, $t-\mathrm{BuOH} / \mathrm{H}_{2} \mathrm{O}, 60^{\circ} \mathrm{C}, 4 \mathrm{~h}, 90 \%$; (xii) 39, $\mathrm{Et}_{3} \mathrm{~N}$, $\mathrm{NaBH}(\mathrm{OAc})_{3}$, DCM, rt, 15 h; (xiii) $\mathrm{HCl}, \mathrm{MeOH}, \mathrm{rt}, 1$ h, 50-72\% (2 steps); (xiv) $\mathrm{KOH}$, $\mathrm{MeOH}, \mathrm{rt}, 1 \mathrm{~h}, 87 \%$ (2 steps); (xv) $\mathrm{BBr}_{3}$, DCM, rt, 24 h, 17-49\%. 


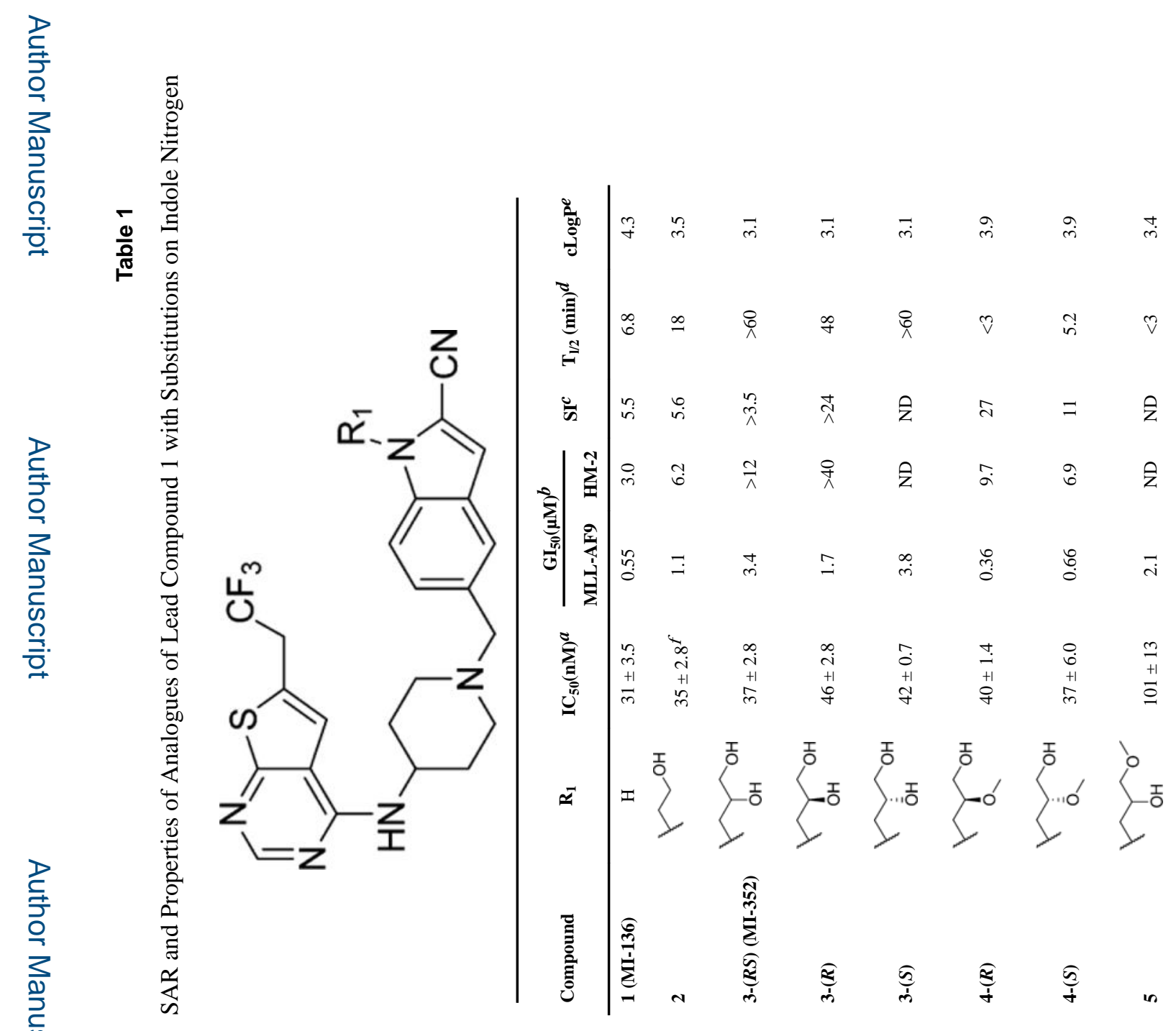



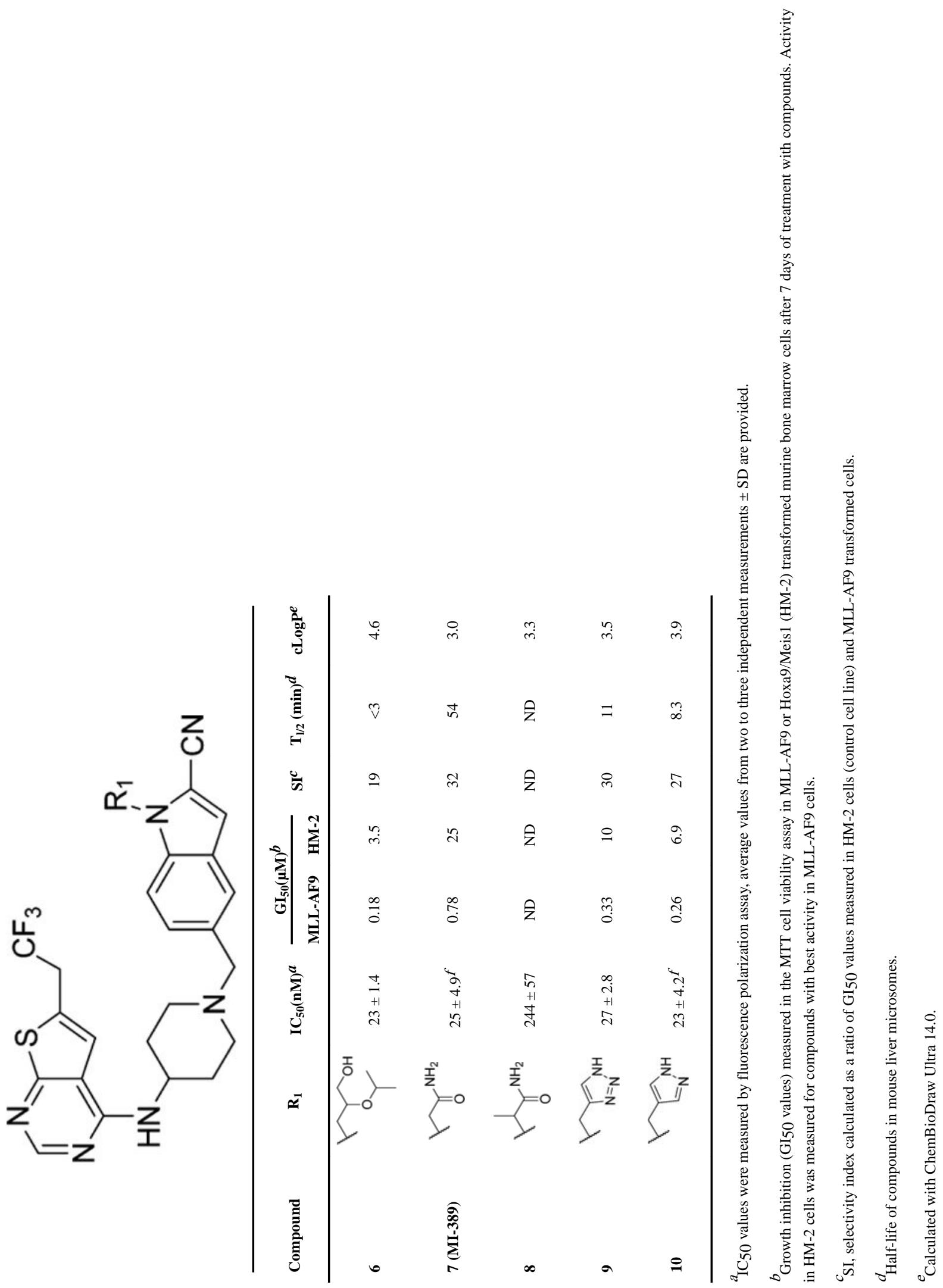

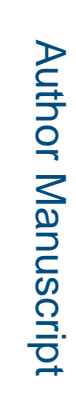

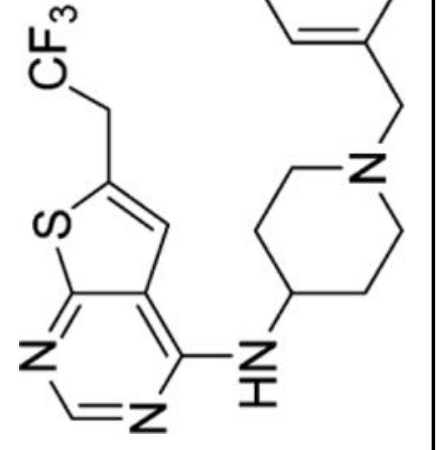

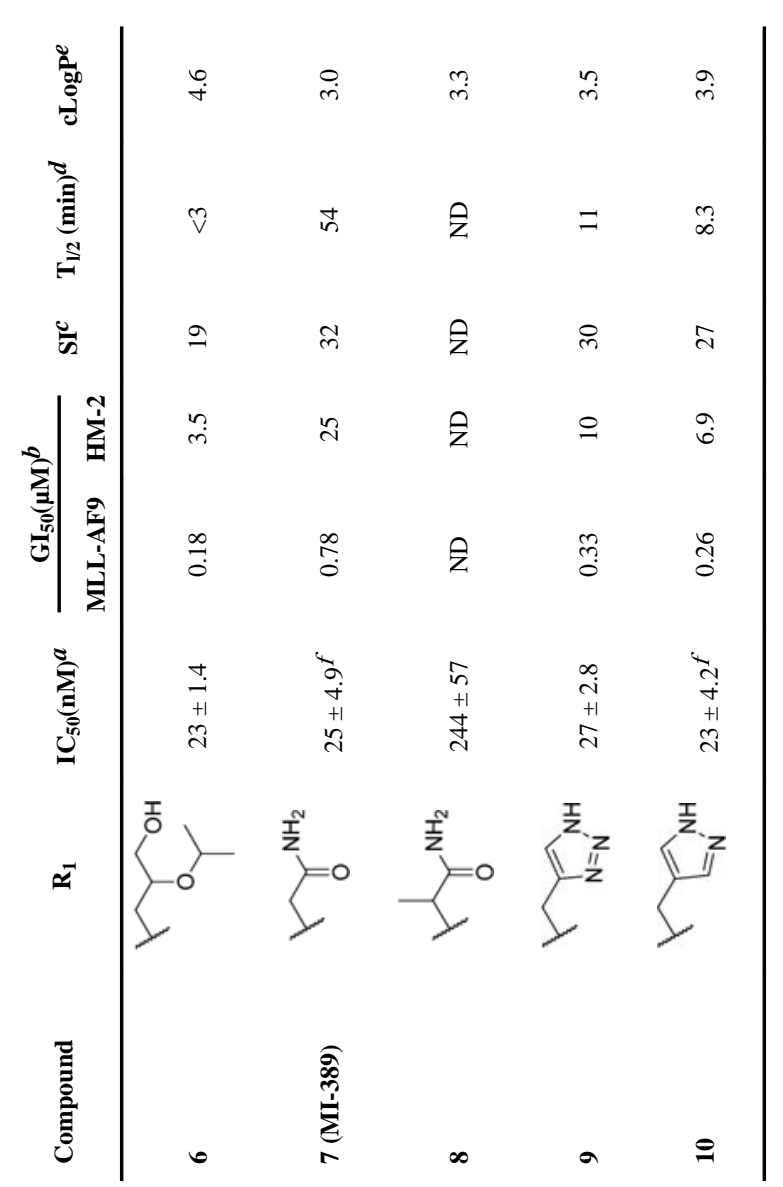

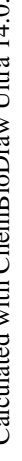



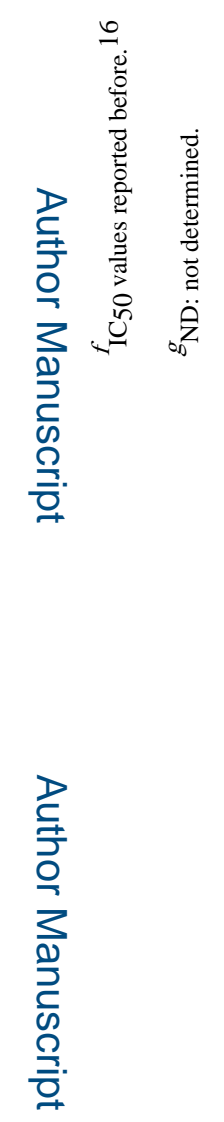

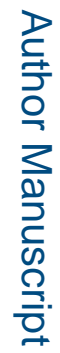

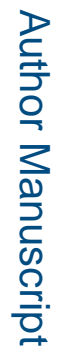

$J$ Med Chem. Author manuscript; available in PMC 2016 November 02. 

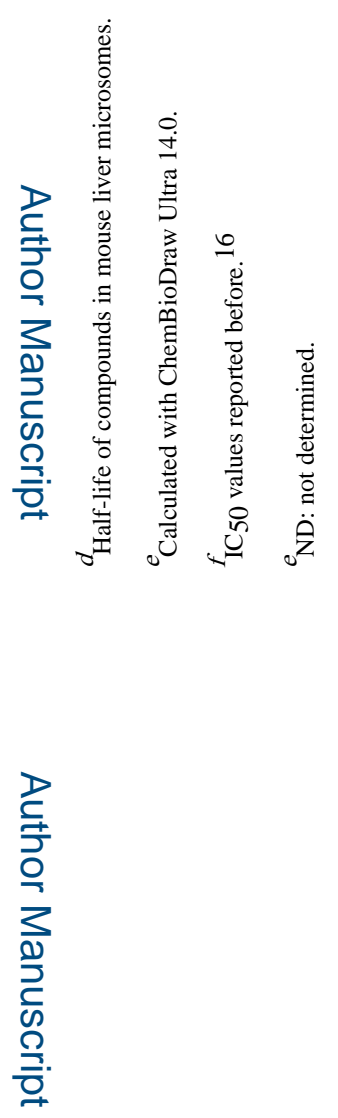

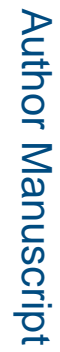

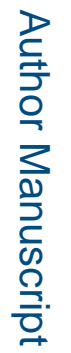

$J$ Med Chem. Author manuscript; available in PMC 2016 November 02. 


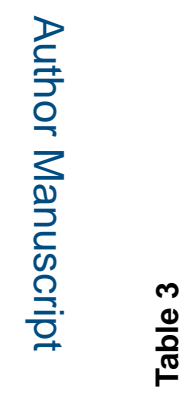

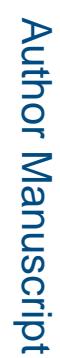

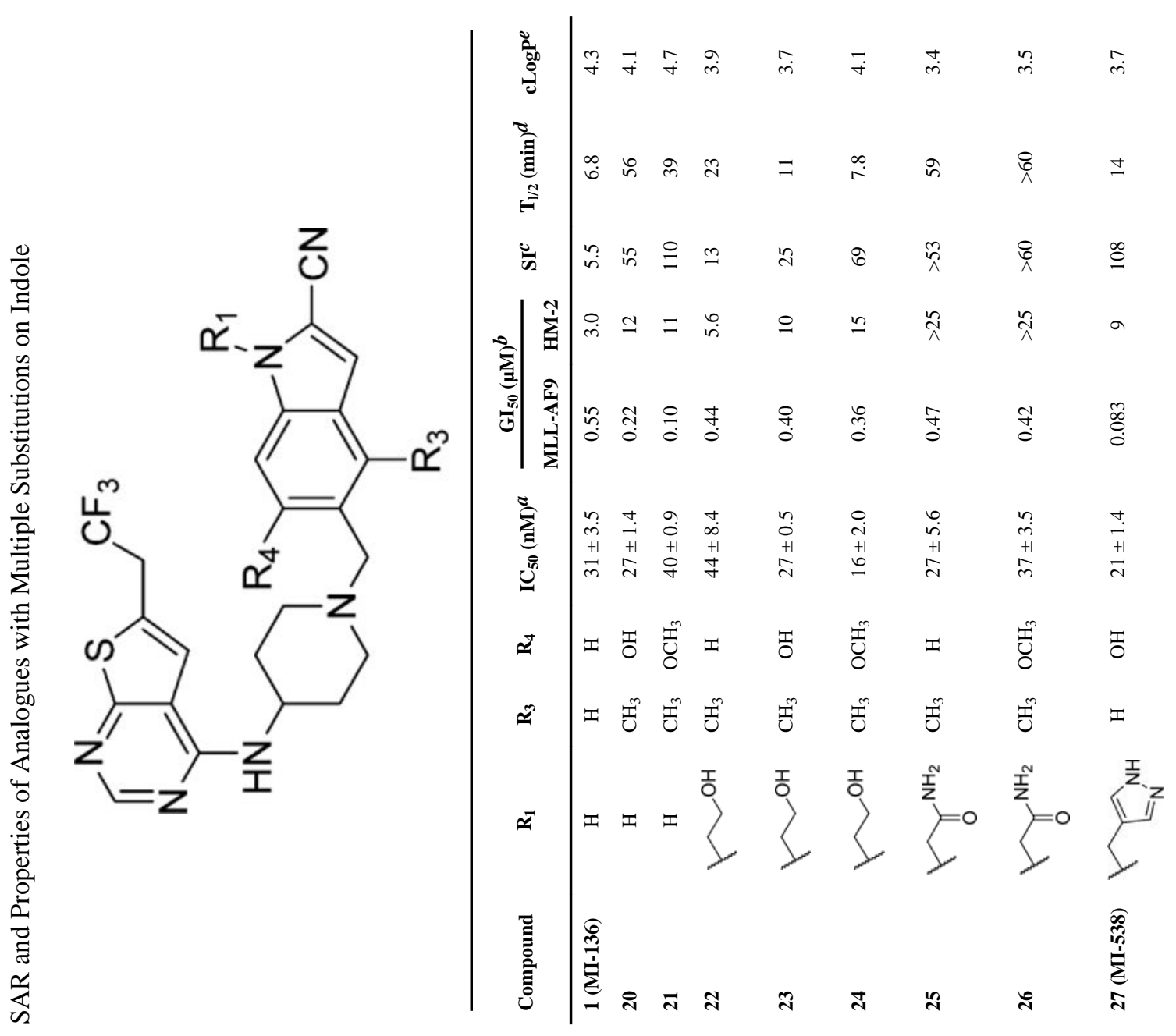

$J$ Med Chem. Author manuscript; available in PMC 2016 November 02. 


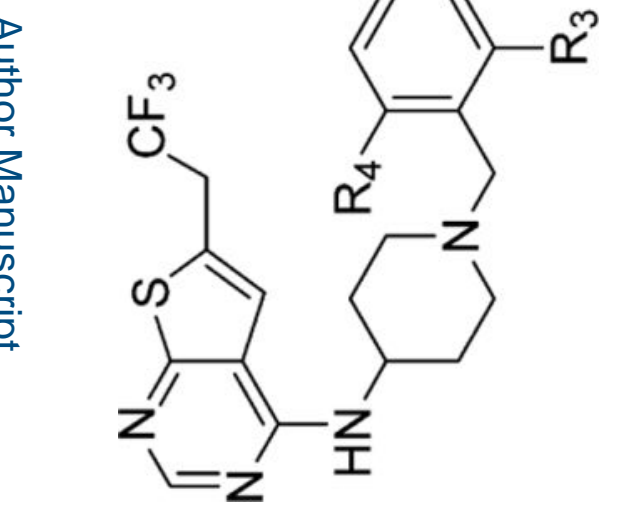




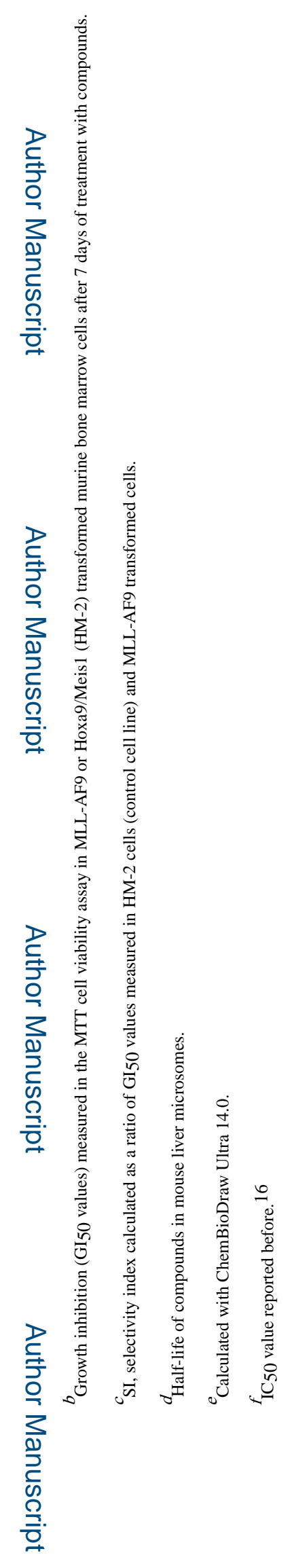




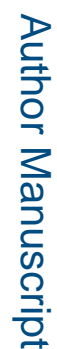

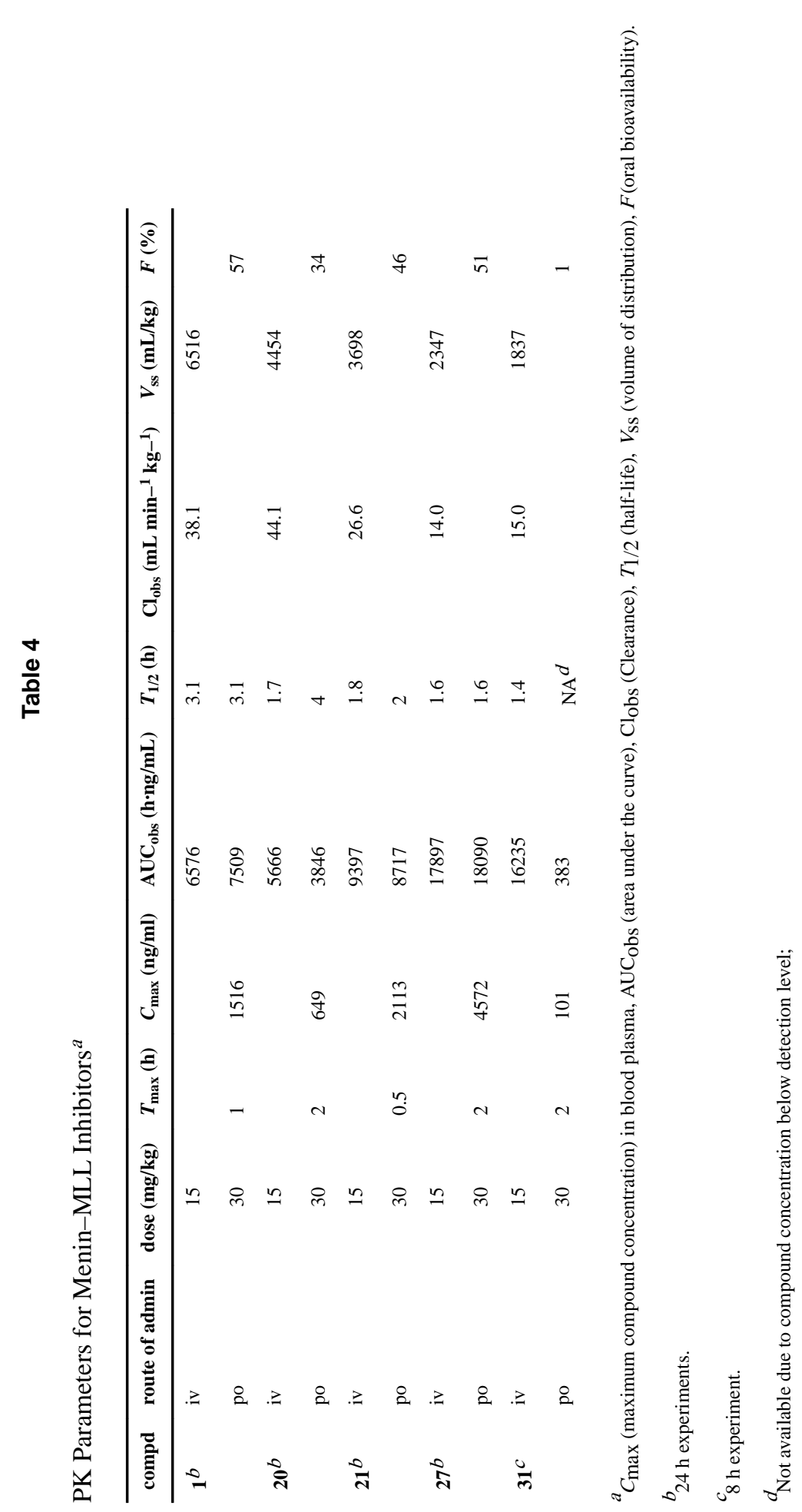

JMed Chem. Author manuscript; available in PMC 2016 November 02. 